\title{
Switching the Regioselectivity Access to Pyrroles and Isoquinolines from Ketoxime Acetates and \\ Ynals
}

Tanggao Liu, Fan Xu, Xiaojuan Liu, Zhiqing Huang, Lipeng Long, Guohai Xu, Hong Xiao,

$$
\text { Zhengwang Chen,* }
$$

Key Laboratory of Organo-Pharmaceutical Chemistry of Jiangxi Province, Gannan Normal University, Ganzhou 341000, PR China

E-mail: chenzwang@126.com

\section{List of Contents}

A. Preparation of starting materials .............................................................2S

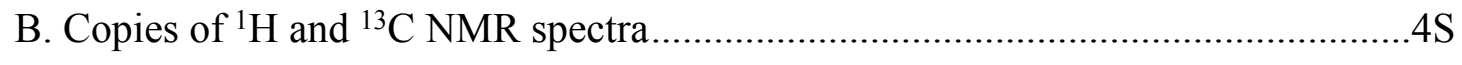

C. X-ray crystallographic data ..................................................................55S 


\section{A. Preparation of starting materials}

The Route toward Substituted ketoxime acetates:<smiles>[R]C(=O)c1ccccc1</smiles>

$A^{\prime}$
1) $\mathrm{NH}_{2} \mathrm{OH} \cdot \mathrm{HCl}$, pyridine

$\mathrm{EtOH}, 60^{\circ} \mathrm{C}$

2) $\mathrm{Ac}_{2} \mathrm{O}, \mathrm{DMAP}$, pyridine, rt

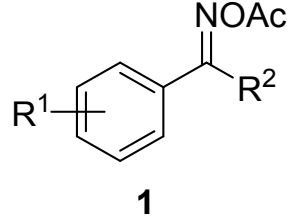

1

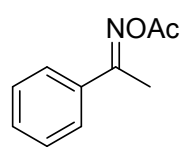

$1 \mathrm{a}$

Known compound<smiles>CC(=O)N=C(C)c1ccc(CC(C)C)cc1</smiles>

$1 \mathrm{e}$

Known compound<smiles>CC(=O)ON=C(C)c1ccco1</smiles>

$1 \mathrm{i}$

Known compound<smiles>CC(=O)ON=C(C)c1ccc(F)cc1</smiles>

$1 \mathrm{~m}$

Known compound<smiles>CC(=O)N=C(C)c1ccc(Cl)cc1</smiles>

$1 \mathrm{q}$

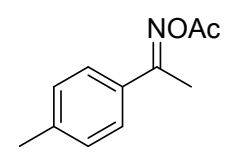

$1 \mathrm{~b}$

Known compound<smiles>CC(=O)N=C(C)c1ccc2ccccc2c1</smiles>

$1 f$

Known compound<smiles>CC(=O)ON=C(C)c1cccs1</smiles>

1j

Known compound<smiles>CCC(=NOC(C)=O)c1ccccc1</smiles>

1n

Known compound

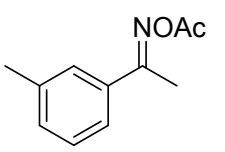

$1 c$

Known compound<smiles>COc1ccc(C(C)=NOC(C)=O)cc1</smiles>

$1 \mathrm{~g}$

Known compound<smiles>CC(=O)ON=C1CCCc2ccccc21</smiles>

$1 \mathrm{k}$

Known compound<smiles>CC(=O)ON=C(c1ccccc1)c1ccccc1</smiles>

10

Known compound<smiles>CC(=O)N=C(C)c1ccccc1C</smiles>

1d

Known compound<smiles>CC(=O)N=C(C)c1ccccc1Br</smiles>

$1 \mathrm{~h}$

Known compound<smiles>CC(=O)ON=C(C)c1ccc(Br)cc1</smiles>

11

Known compound<smiles>COc1ccccc1/C(C)=N/OC(C)=O</smiles>

$1 p$

Known compound

Known compound

Scheme S1. The structure of ketoxime acetates.

The Route toward Substituted ynals:<smiles>[R]c1cccc([Al]C#CCO)c1</smiles>

B'

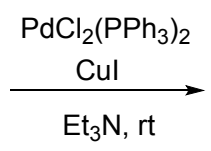

$\mathrm{Et}_{3} \mathrm{~N}, \mathrm{rt}$<smiles>[R][X]1ccc(C#CCO)cc1</smiles>

$\mathbf{C}^{\prime}$

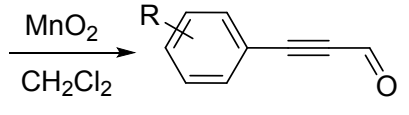

2 


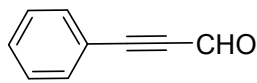

$2 a$

Commercially available<smiles>COc1ccc(C#CC=O)cc1</smiles>

$2 e$

Known compound

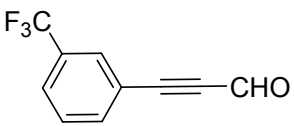

$2 \mathrm{i}$

Known compound

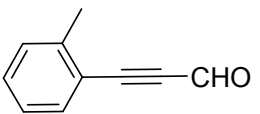

$2 m$

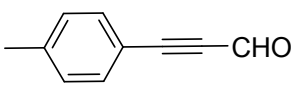

$2 b$<smiles>COc1ccccc1C#CC=O</smiles>

$2 f$

Known compound<smiles>O=CC#Cc1cccs1</smiles>

2j

Known compound<smiles>O=CC#Cc1ccc(-c2ccccc2)cc1</smiles>

$2 n$

Known compound

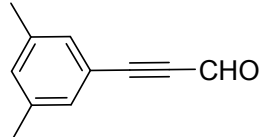

2c

Known compound<smiles>CC#Cc1ccc2c(c1)OCO2</smiles>

$2 \mathrm{~g}$

Known compound

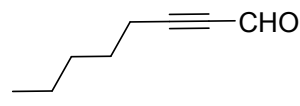

2k

Commercially available<smiles>O=CC#Cc1ccc(F)cc1</smiles>

20

Known compound<smiles>CC(C)(C)c1ccc(C#CC=O)cc1</smiles>

2d

Known compound<smiles>CC(=O)c1ccc(C#CC=O)cc1</smiles>

2h

Known compound

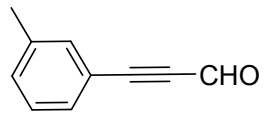

2I

Known compound<smiles>O=CC#Cc1ccc(Cl)cc1</smiles>

$2 p$
Known compound<smiles>COOCCC#Cc1ccc(Br)cc1</smiles><smiles>O=CC#Cc1ccc(I)cc1</smiles>

$2 r$

Known compound

Known compound

Scheme S2. The structure of ynals. 


\section{B. Copies of ${ }^{1} \mathrm{H}$ and ${ }^{13} \mathrm{C}$ NMR spectra}

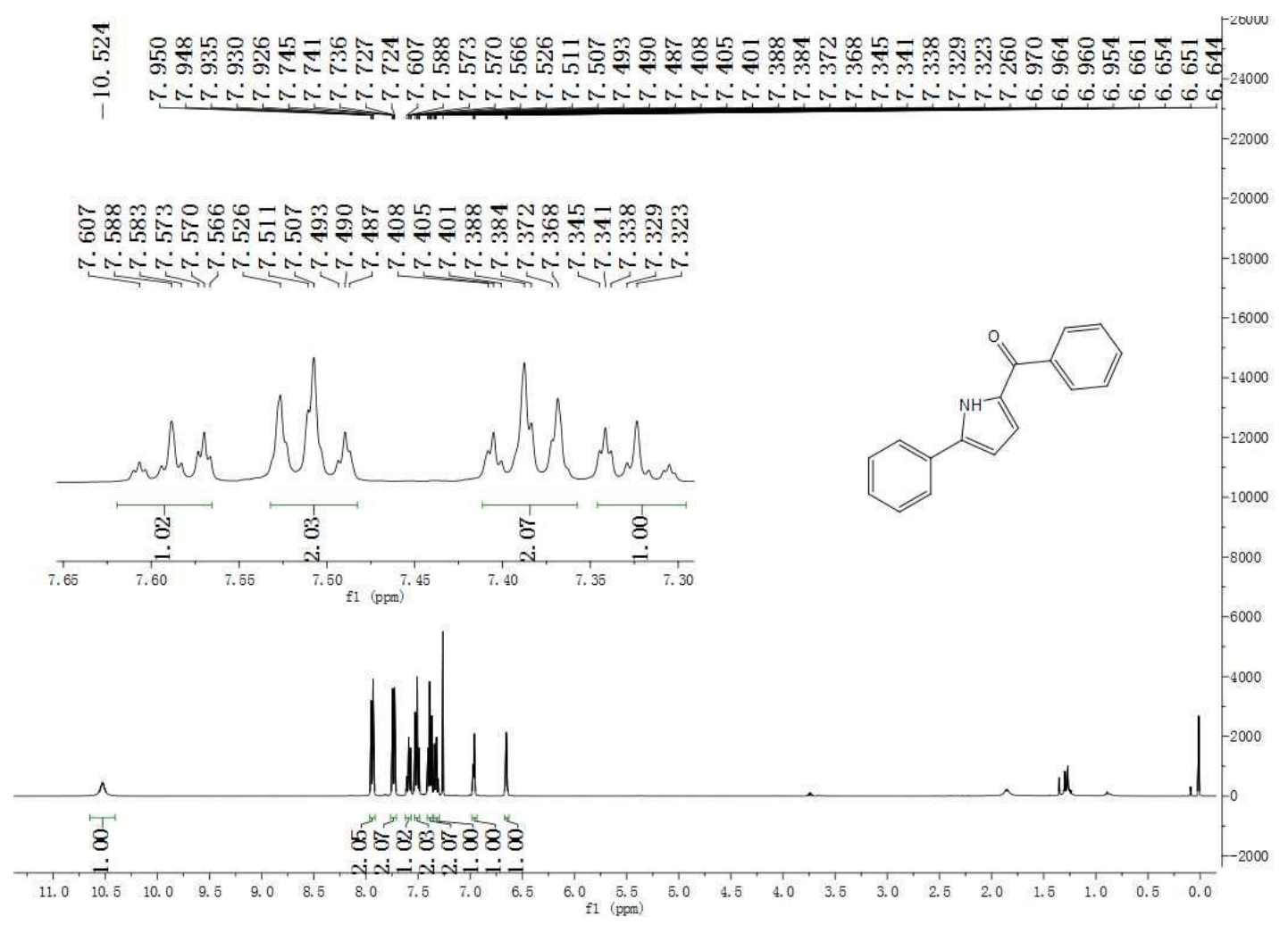

Figure S1. $400 \mathrm{MHz}{ }^{1} \mathrm{H}$ NMR spectrum of $\mathbf{3 a}$ in $\mathrm{CDCl}_{3}$

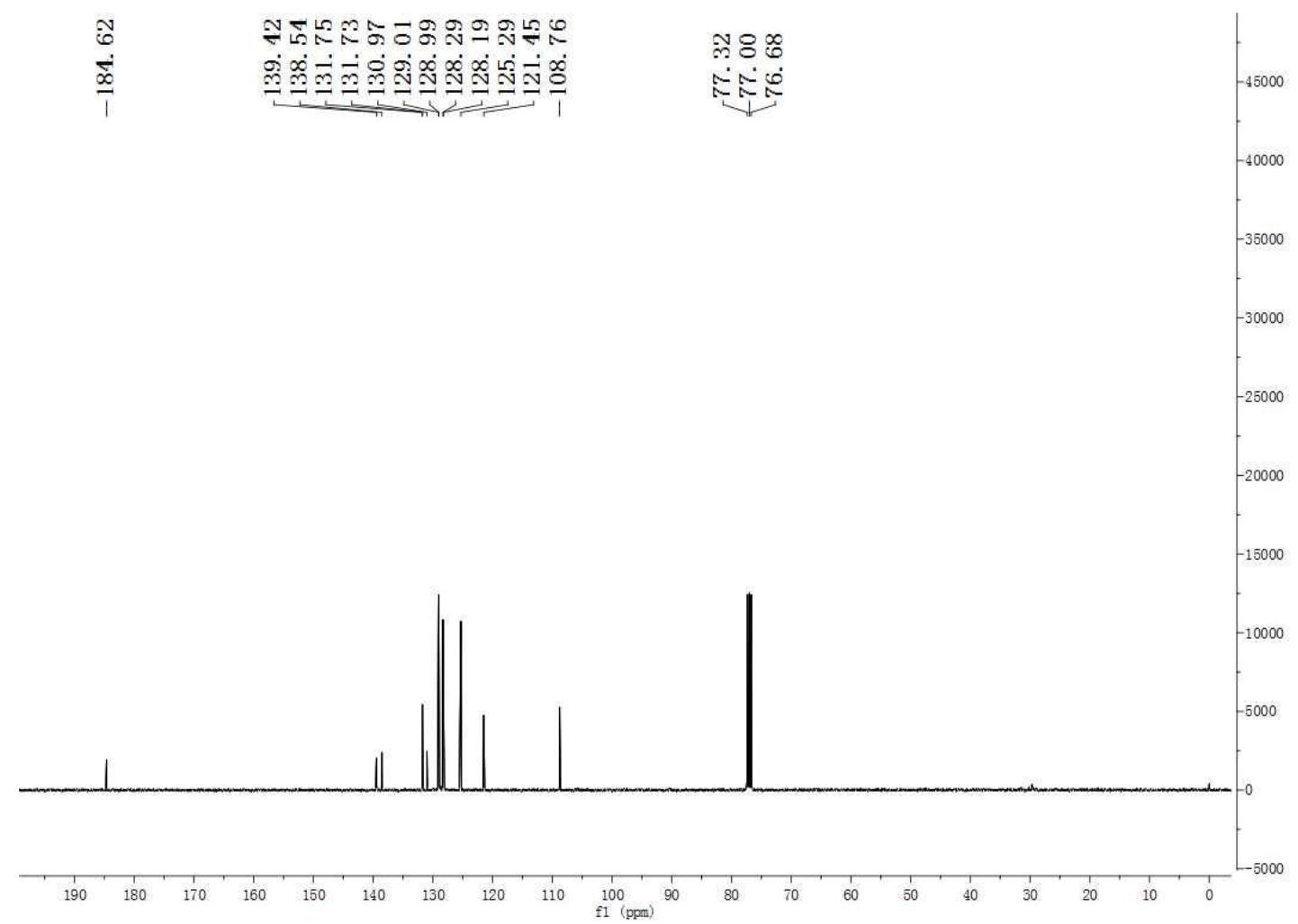

Figure S2. $100 \mathrm{MHz}{ }^{13} \mathrm{C}\left\{{ }^{1} \mathrm{H}\right\}$ NMR spectrum of $\mathbf{3 a}$ in $\mathrm{CDCl}_{3}$. 


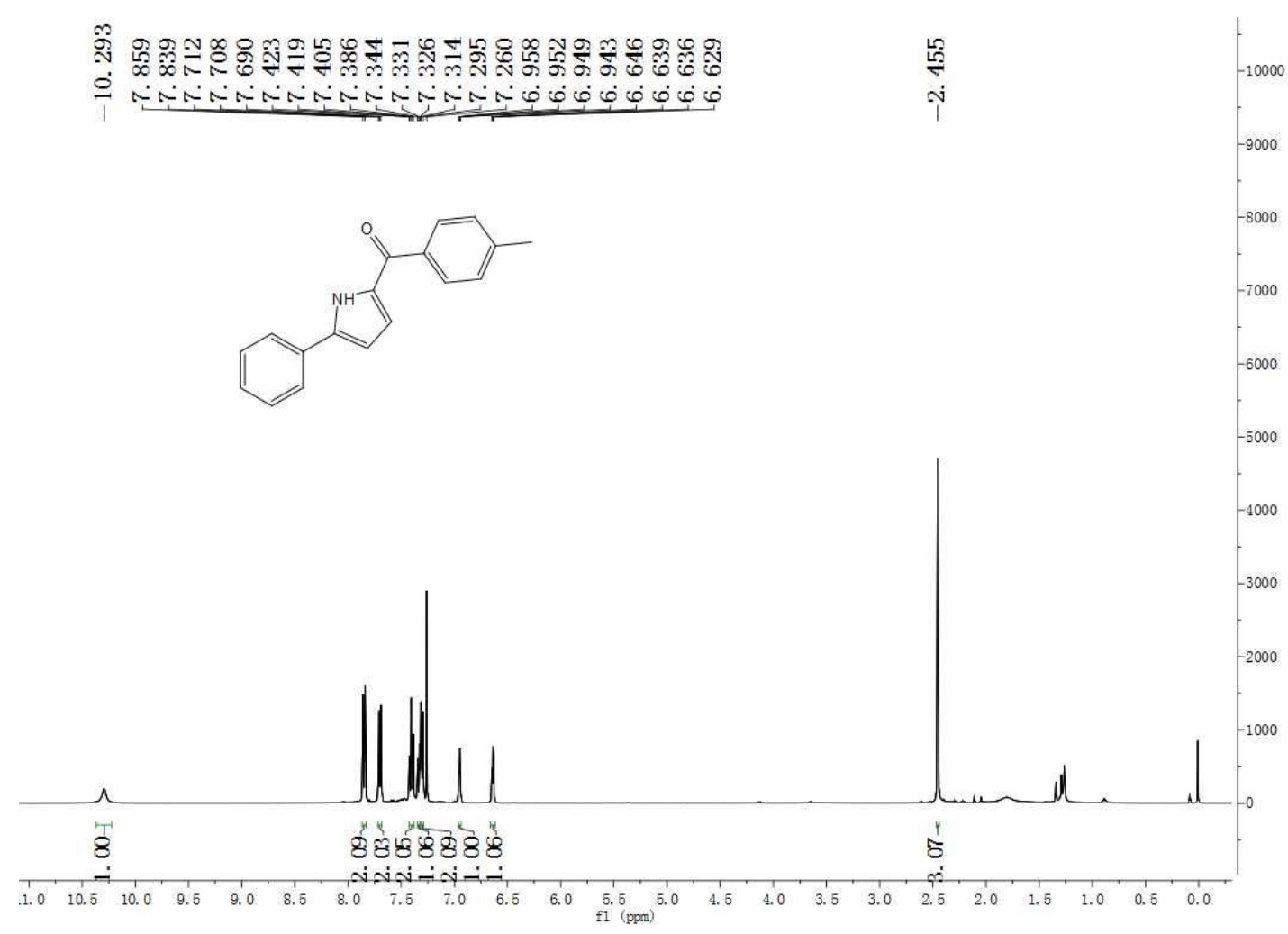

Figure S3. $400 \mathrm{MHz}{ }^{1} \mathrm{H}$ NMR spectrum of $\mathbf{3 b}$ in $\mathrm{CDCl}_{3}$

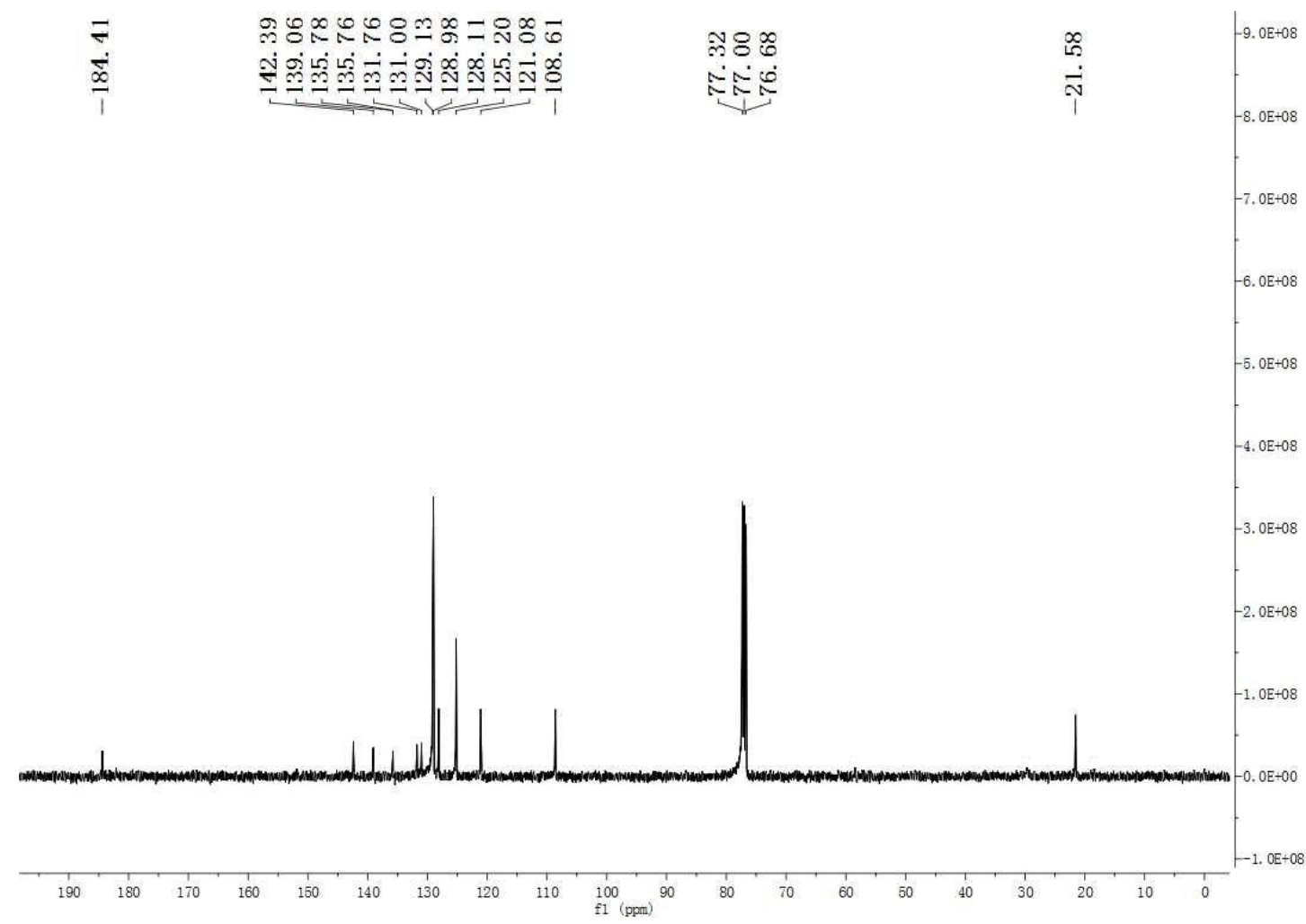

Figure S4. $100 \mathrm{MHz}{ }^{13} \mathrm{C}\left\{{ }^{1} \mathrm{H}\right\}$ NMR spectrum of $\mathbf{3 b}$ in $\mathrm{CDCl}_{3}$. 


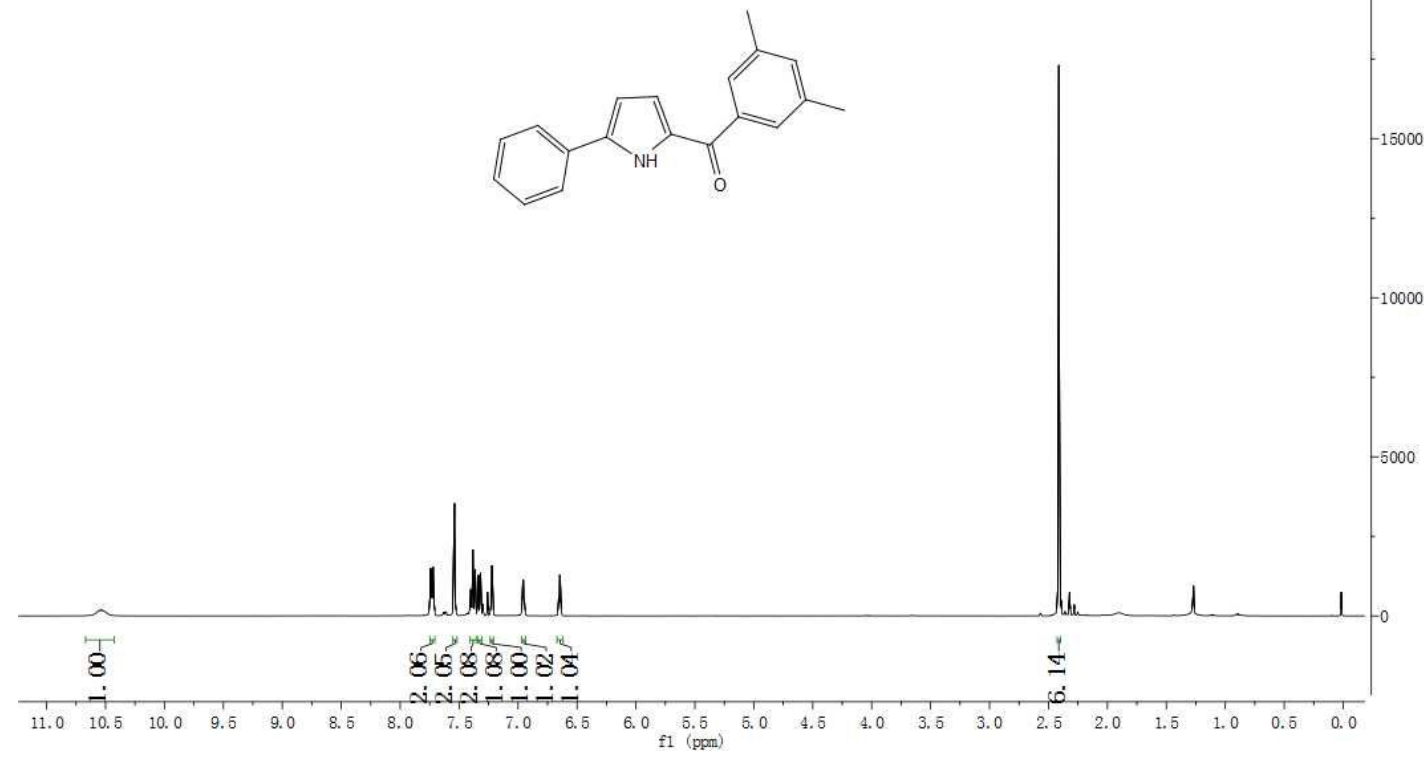

Figure S5. $400 \mathrm{MHz}{ }^{1} \mathrm{H}$ NMR spectrum of $\mathbf{3 c}$ in $\mathrm{CDCl}_{3}$

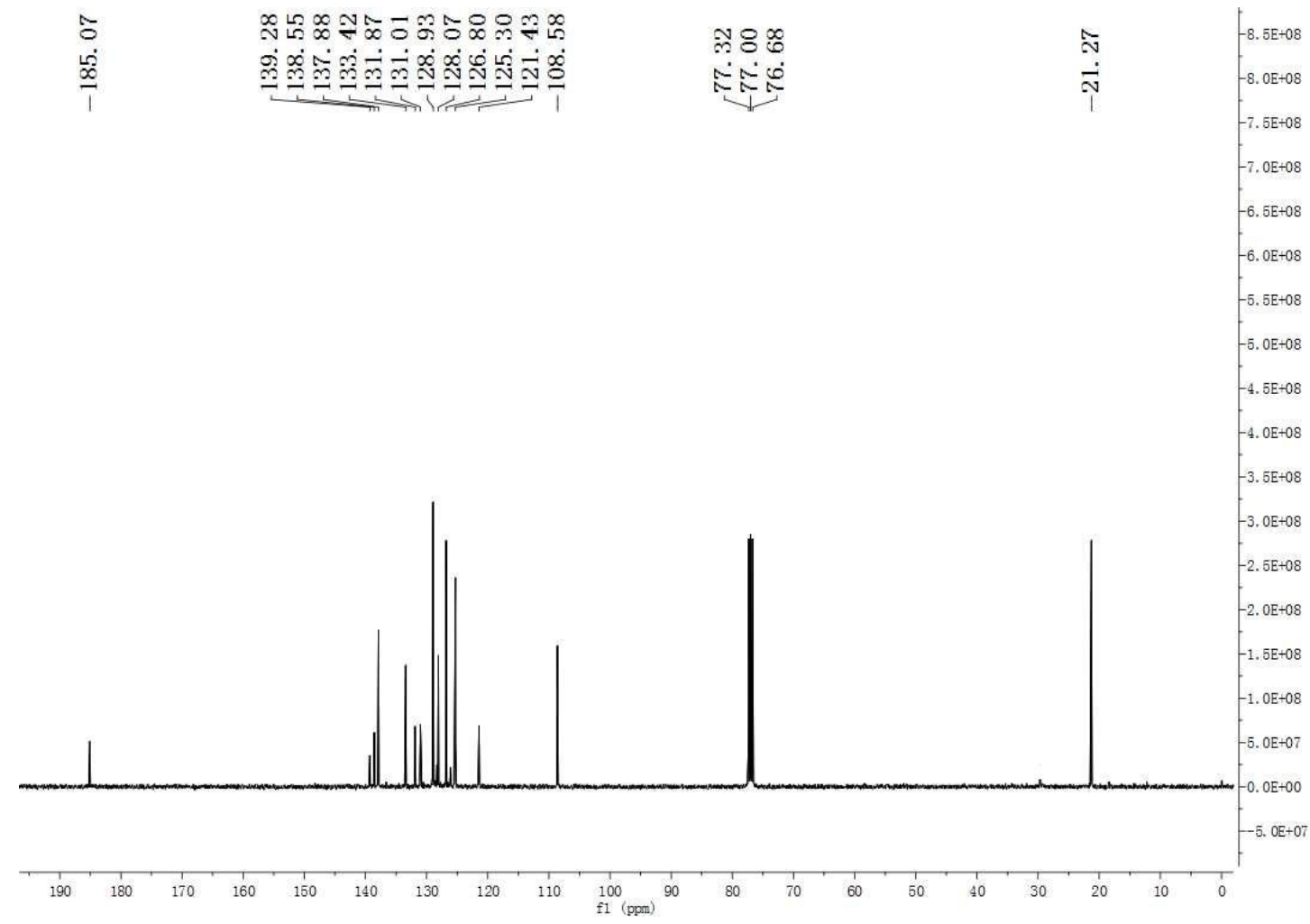

Figure S6. $100 \mathrm{MHz}{ }^{13} \mathrm{C}\left\{{ }^{1} \mathrm{H}\right\}$ NMR spectrum of $\mathbf{3 c}$ in $\mathrm{CDCl}_{3}$. 


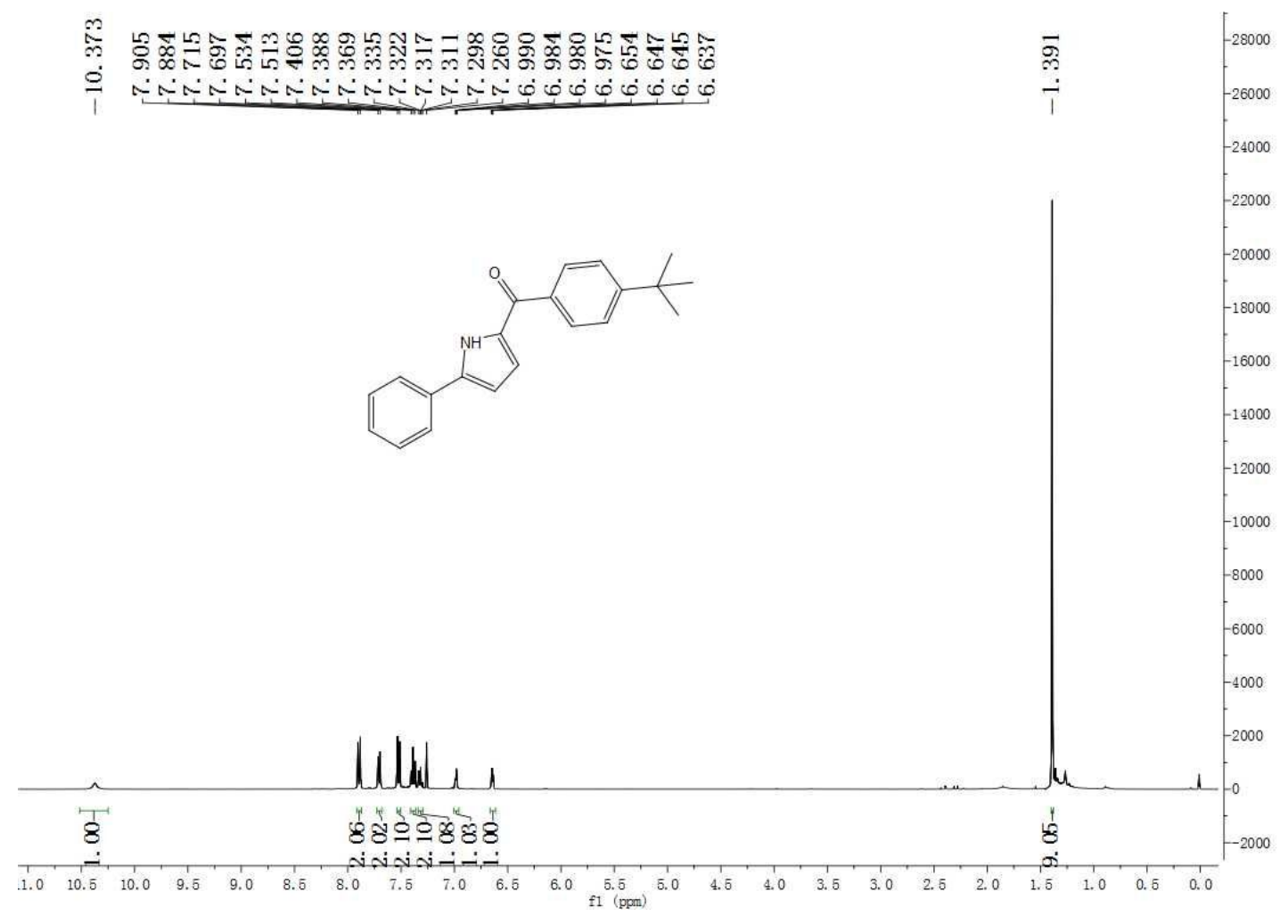

Figure S7. $400 \mathrm{MHz}{ }^{1} \mathrm{H}$ NMR spectrum of $\mathbf{3 d}$ in $\mathrm{CDCl}_{3}$

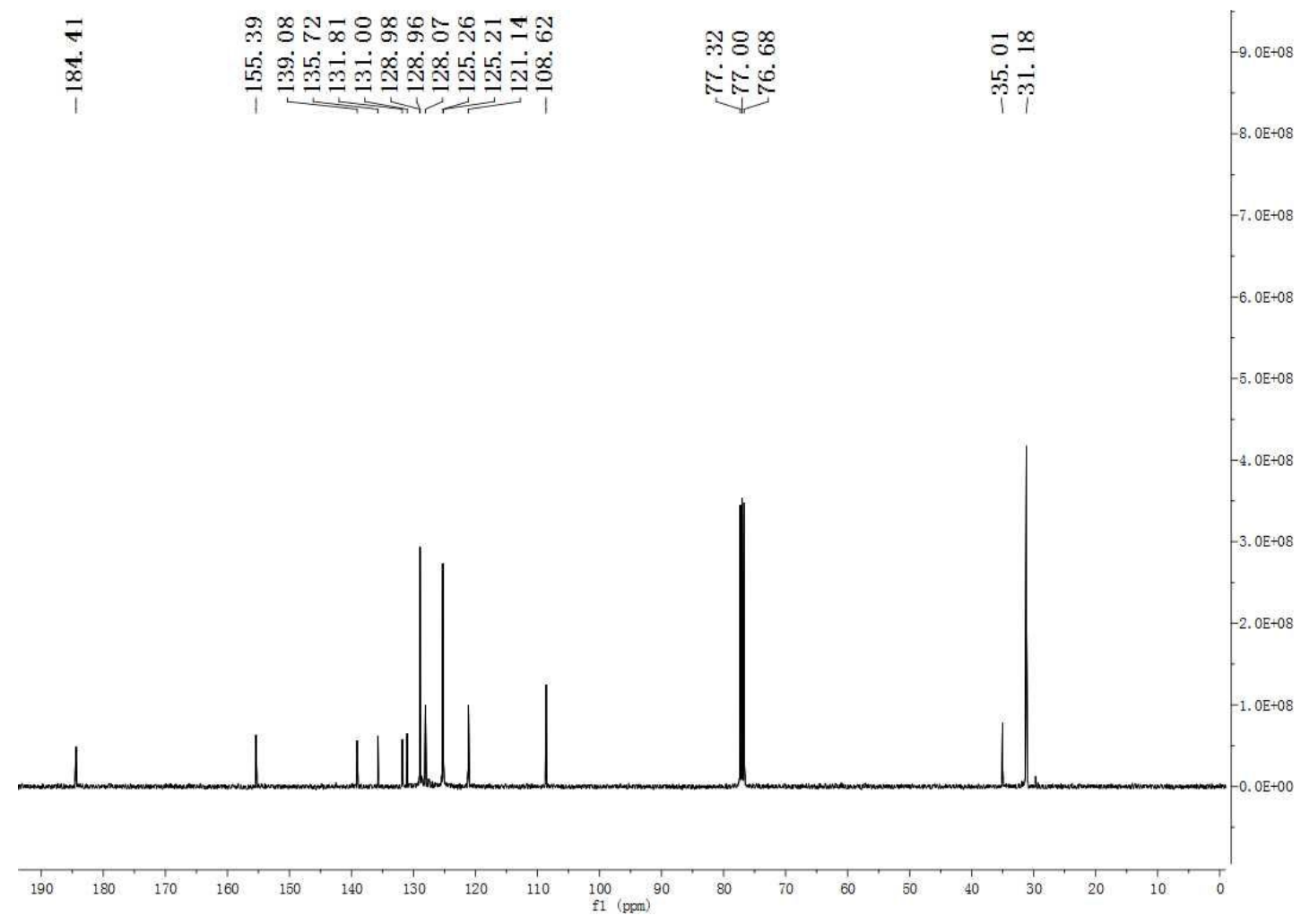

Figure S8. $100 \mathrm{MHz}{ }^{13} \mathrm{C}\left\{{ }^{1} \mathrm{H}\right\} \mathrm{NMR}$ spectrum of $\mathbf{3 d}$ in $\mathrm{CDCl}_{3}$. 


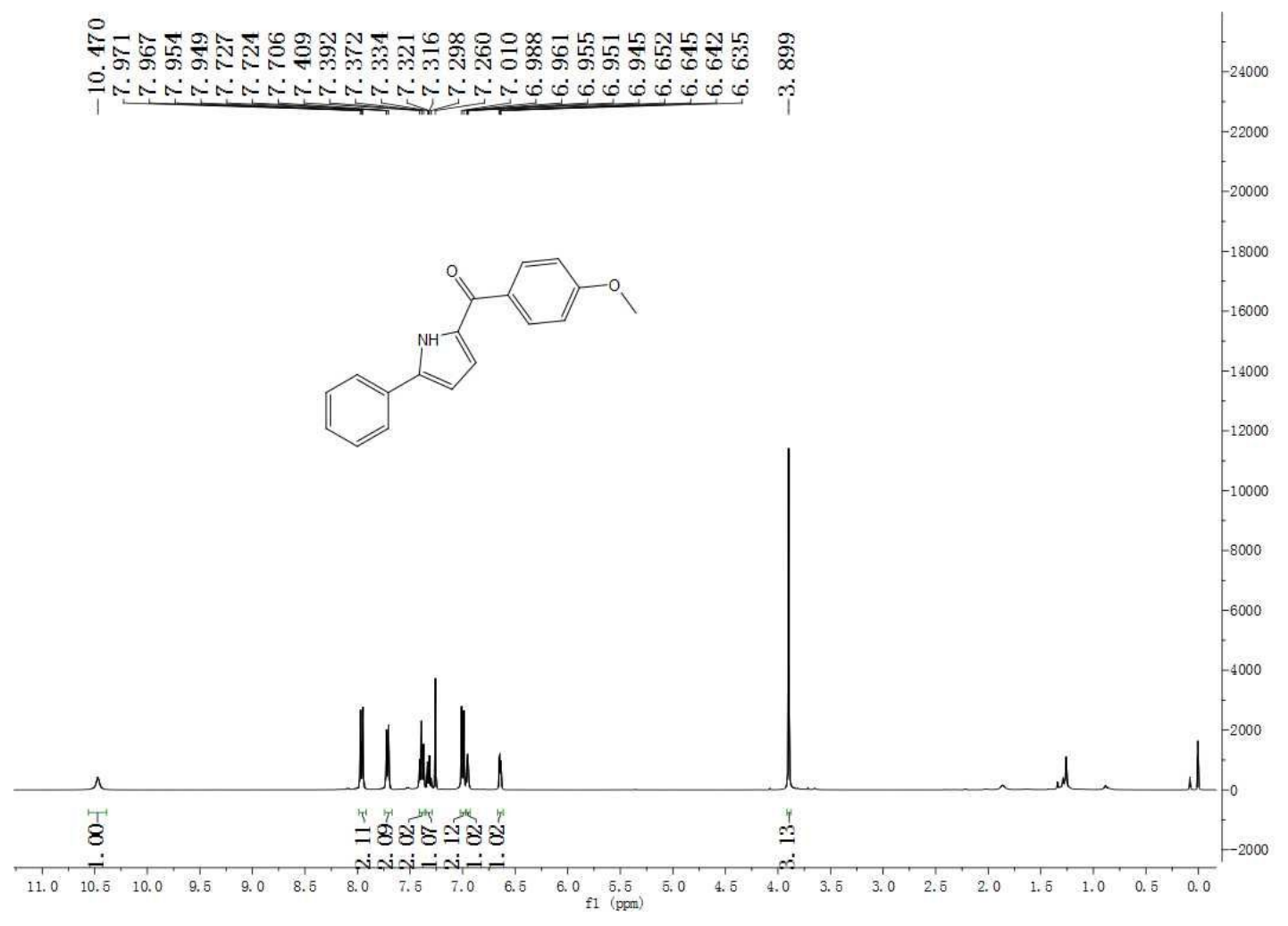

Figure S9. $400 \mathrm{MHz}{ }^{1} \mathrm{H} \mathrm{NMR}$ spectrum of $\mathbf{3 e}$ in $\mathrm{CDCl}_{3}$

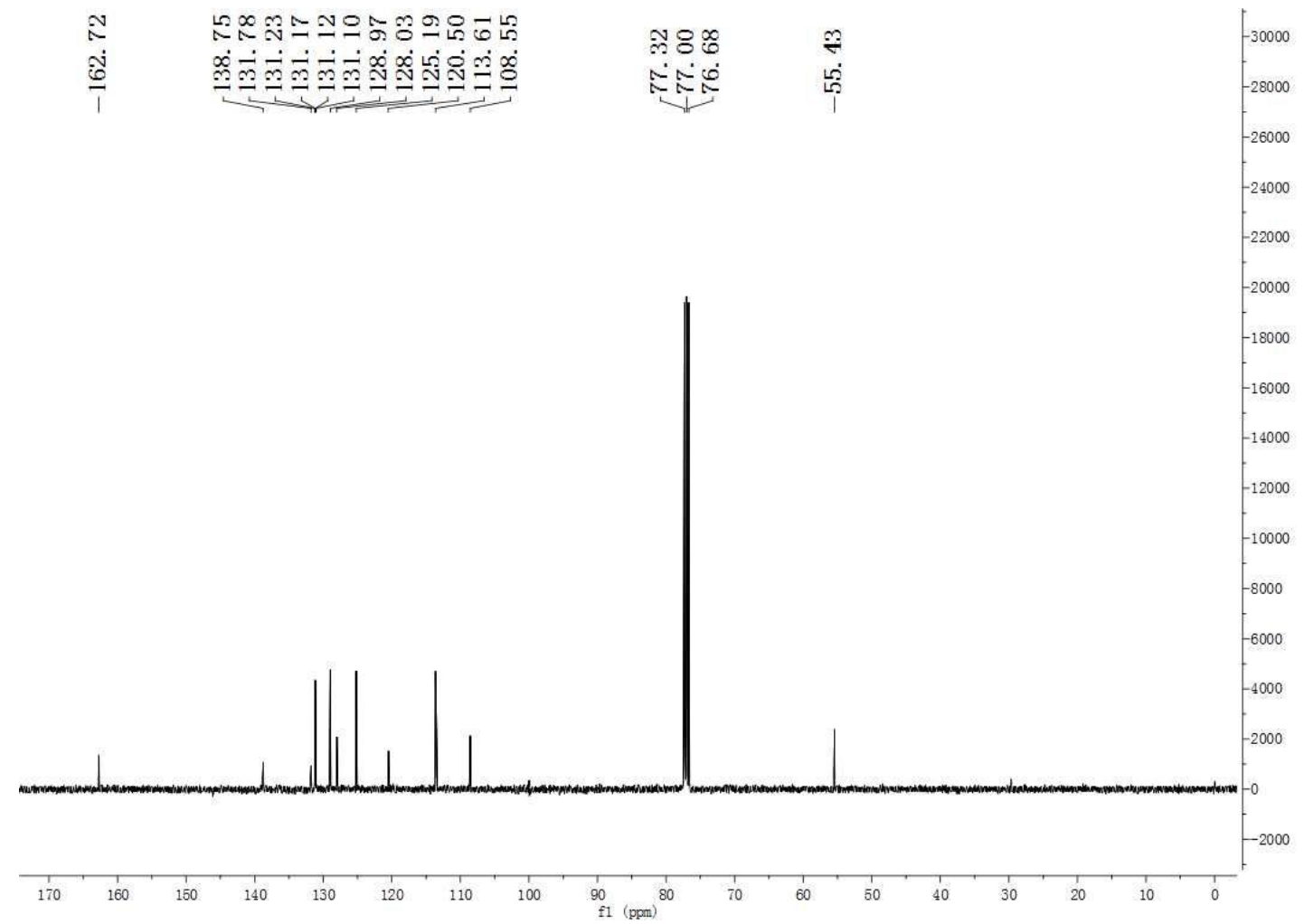

Figure S10. $100 \mathrm{MHz}{ }^{13} \mathrm{C}\left\{{ }^{1} \mathrm{H}\right\}$ NMR spectrum of $\mathbf{3 e}$ in $\mathrm{CDCl}_{3}$. 


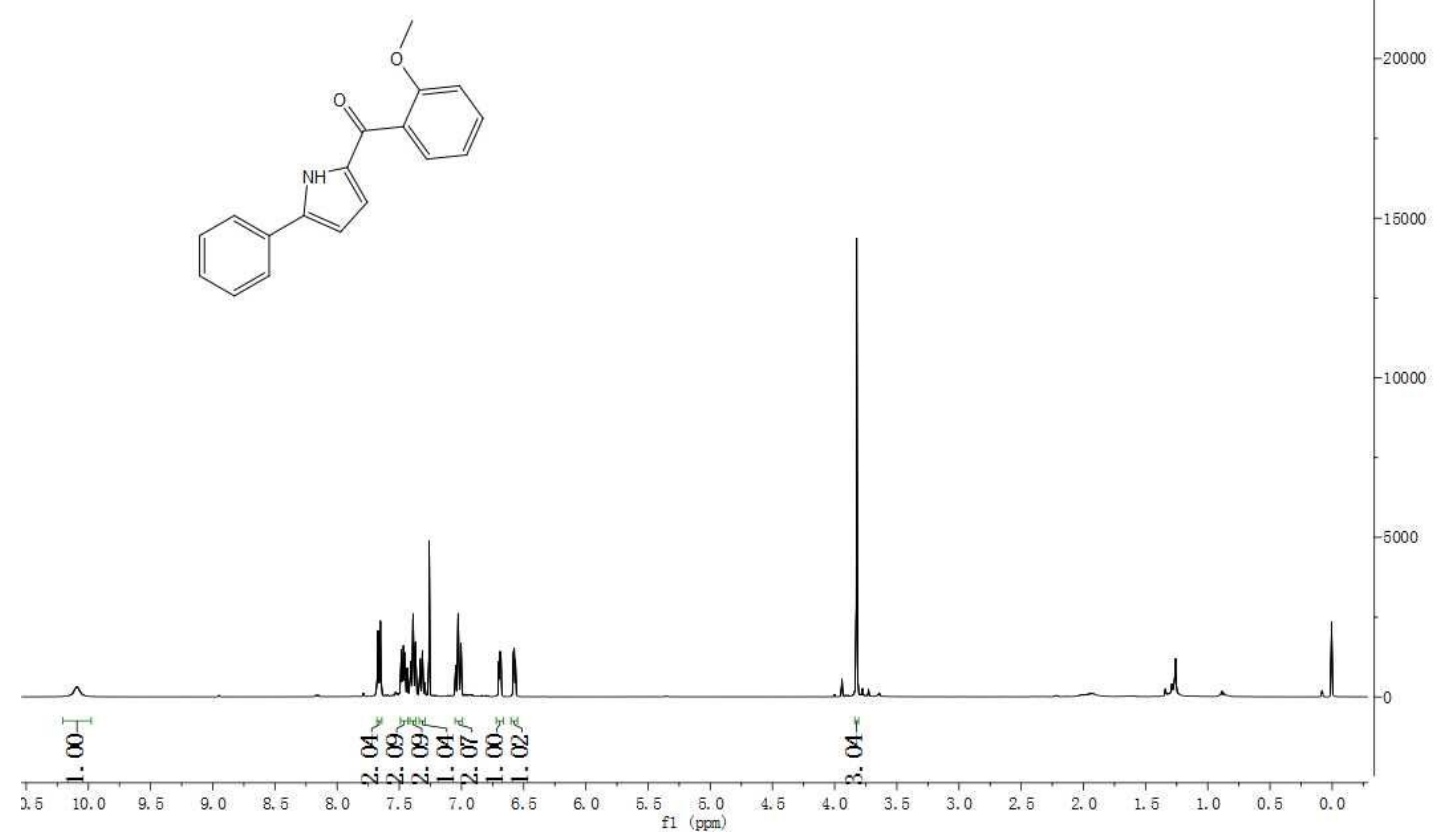

Figure S11. $400 \mathrm{MHz}{ }^{1} \mathrm{H}$ NMR spectrum of $\mathbf{3 f}$ in $\mathrm{CDCl}_{3}$

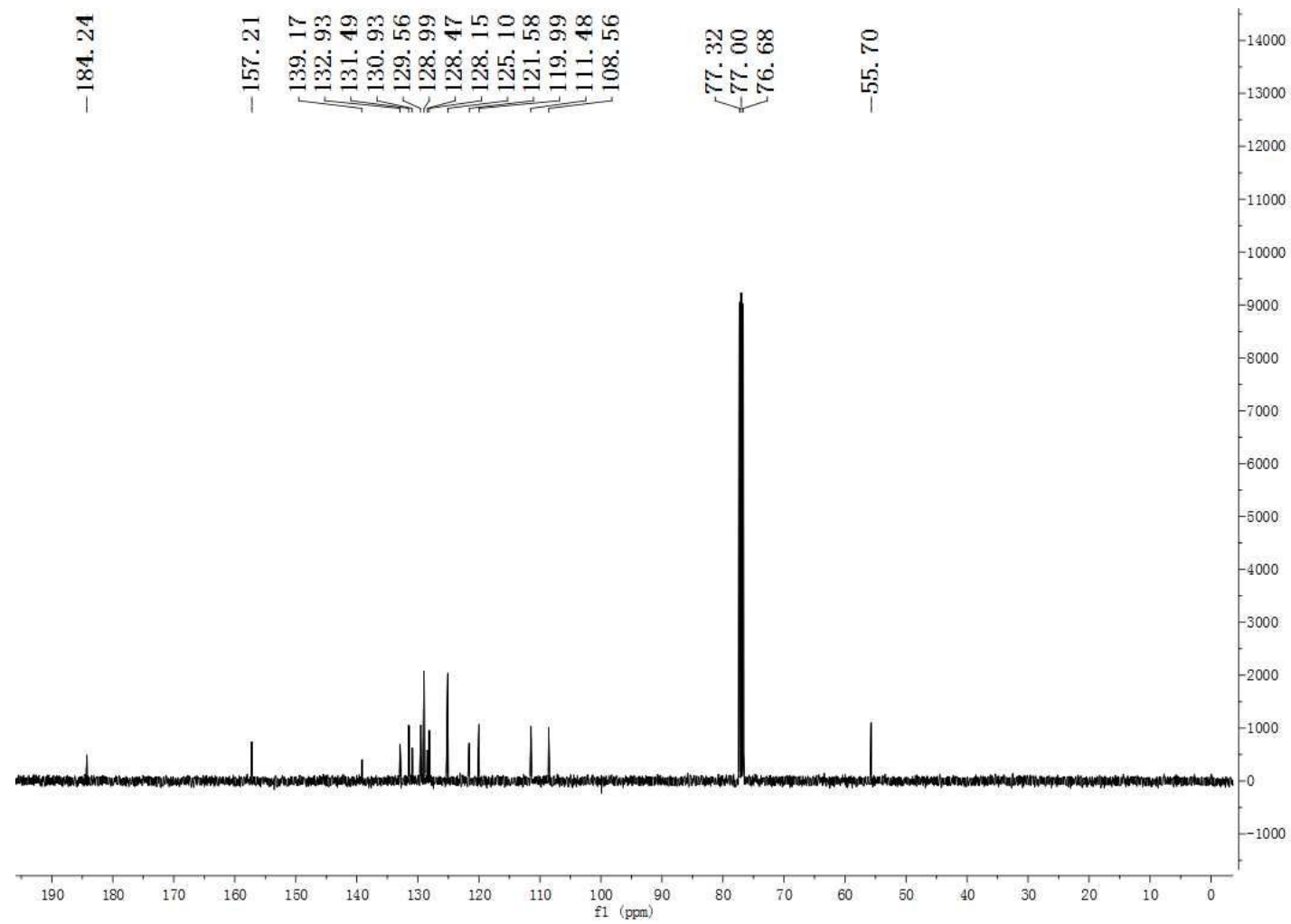

Figure S12. $100 \mathrm{MHz}{ }^{13} \mathrm{C}\left\{{ }^{1} \mathrm{H}\right\}$ NMR spectrum of $\mathbf{3 f}$ in $\mathrm{CDCl}_{3}$. 


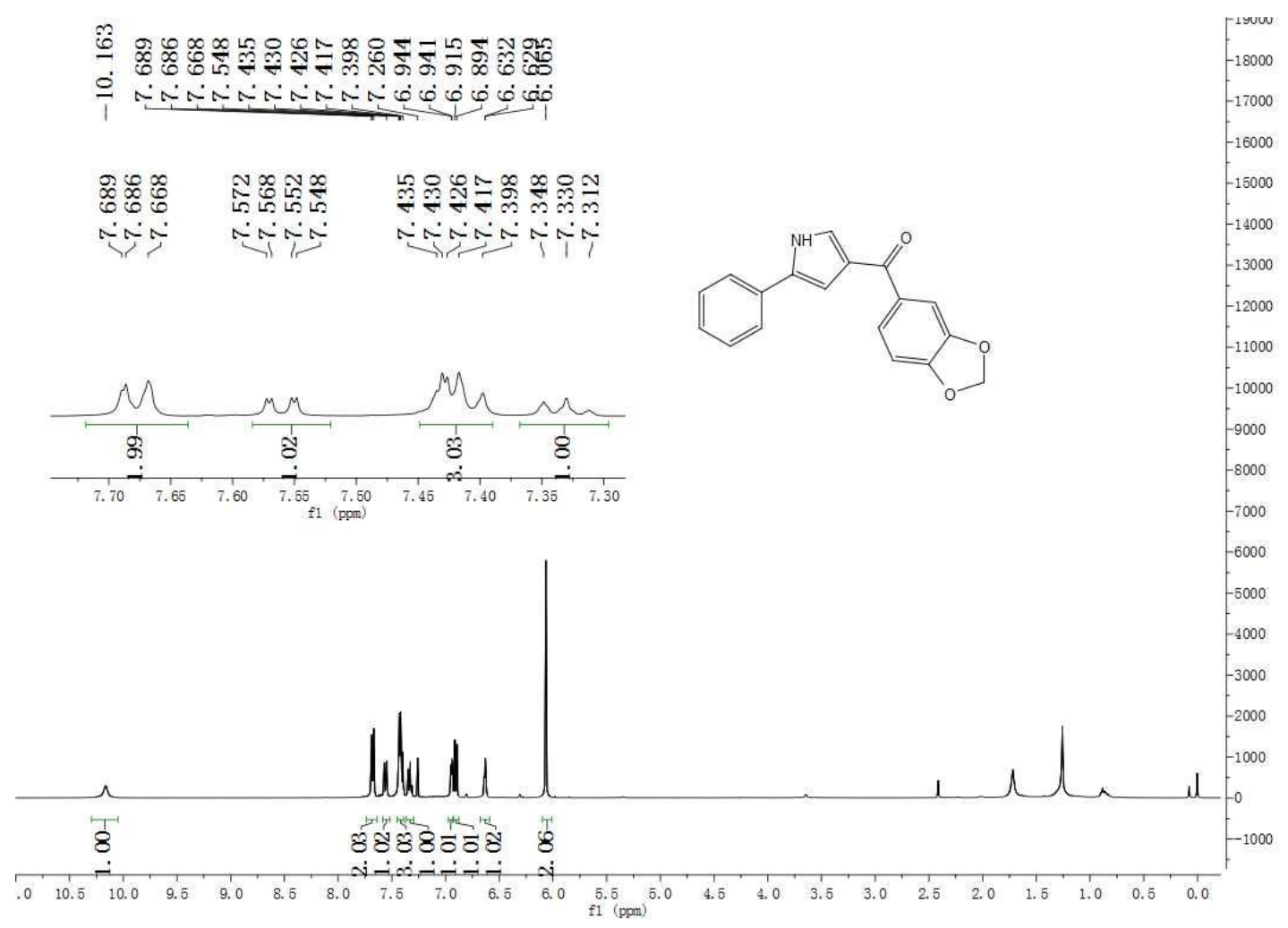

Figure S13. $400 \mathrm{MHz}{ }^{1} \mathrm{H}$ NMR spectrum of $\mathbf{3 g}$ in $\mathrm{CDCl}_{3}$

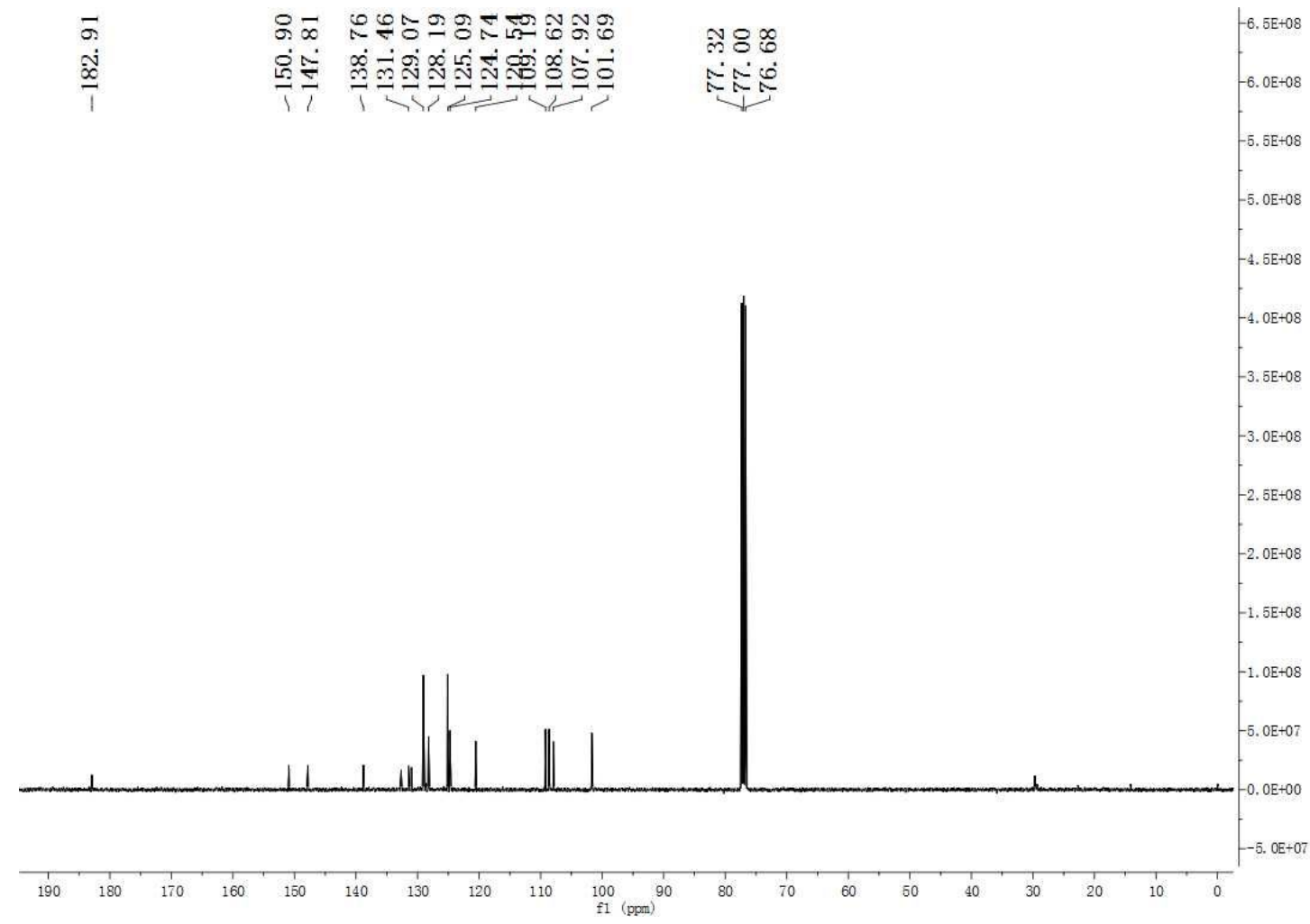

Figure S14. $100 \mathrm{MHz}{ }^{13} \mathrm{C}\left\{{ }^{1} \mathrm{H}\right\} \mathrm{NMR}$ spectrum of $\mathbf{3 g}$ in $\mathrm{CDCl}_{3}$. 
ฟ

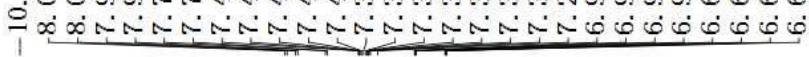

ลิ

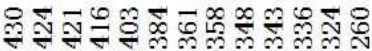

í

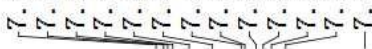
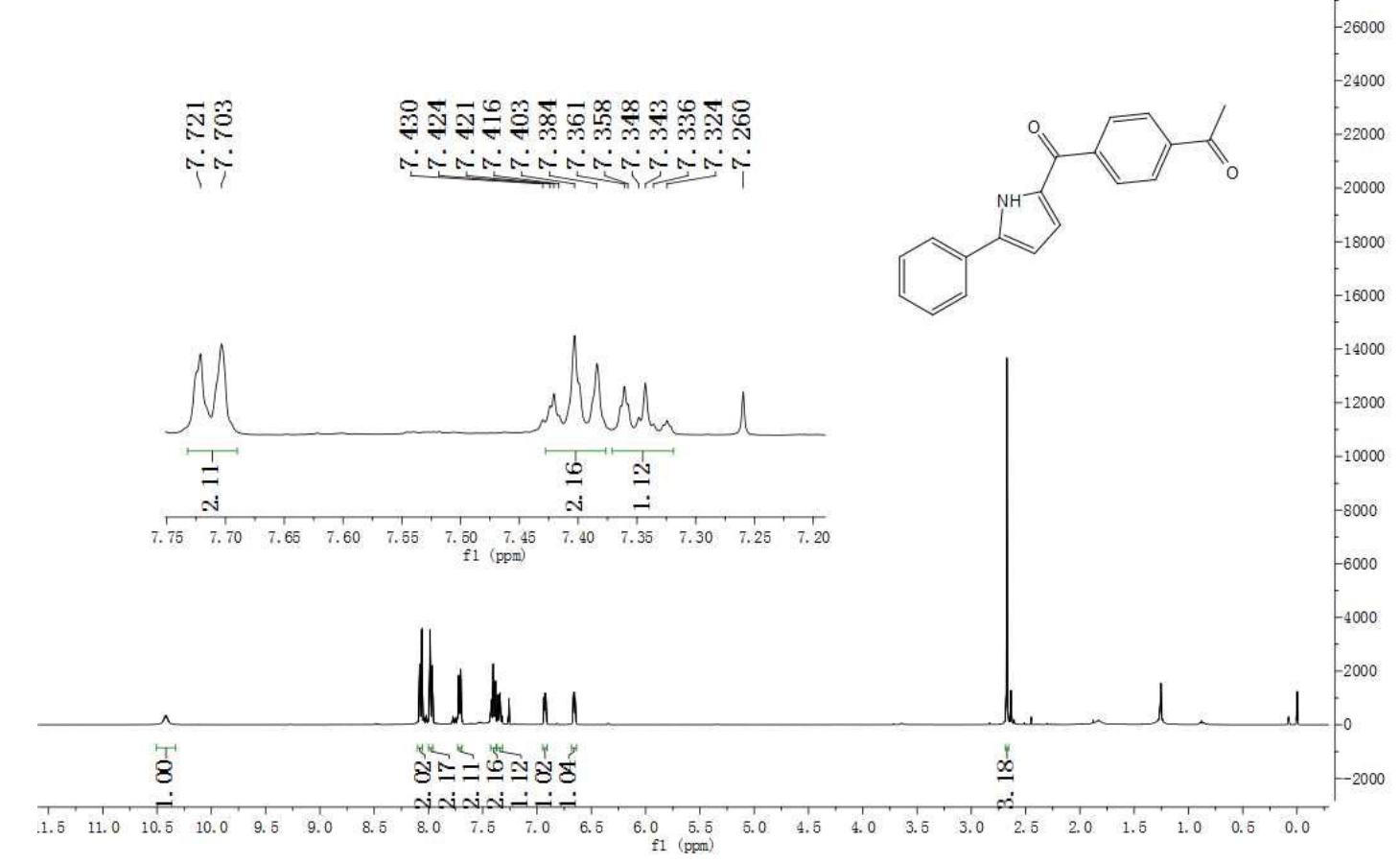

Figure S15. $400 \mathrm{MHz}{ }^{1} \mathrm{H} \mathrm{NMR}$ spectrum of $\mathbf{3 h}$ in $\mathrm{CDCl}_{3}$

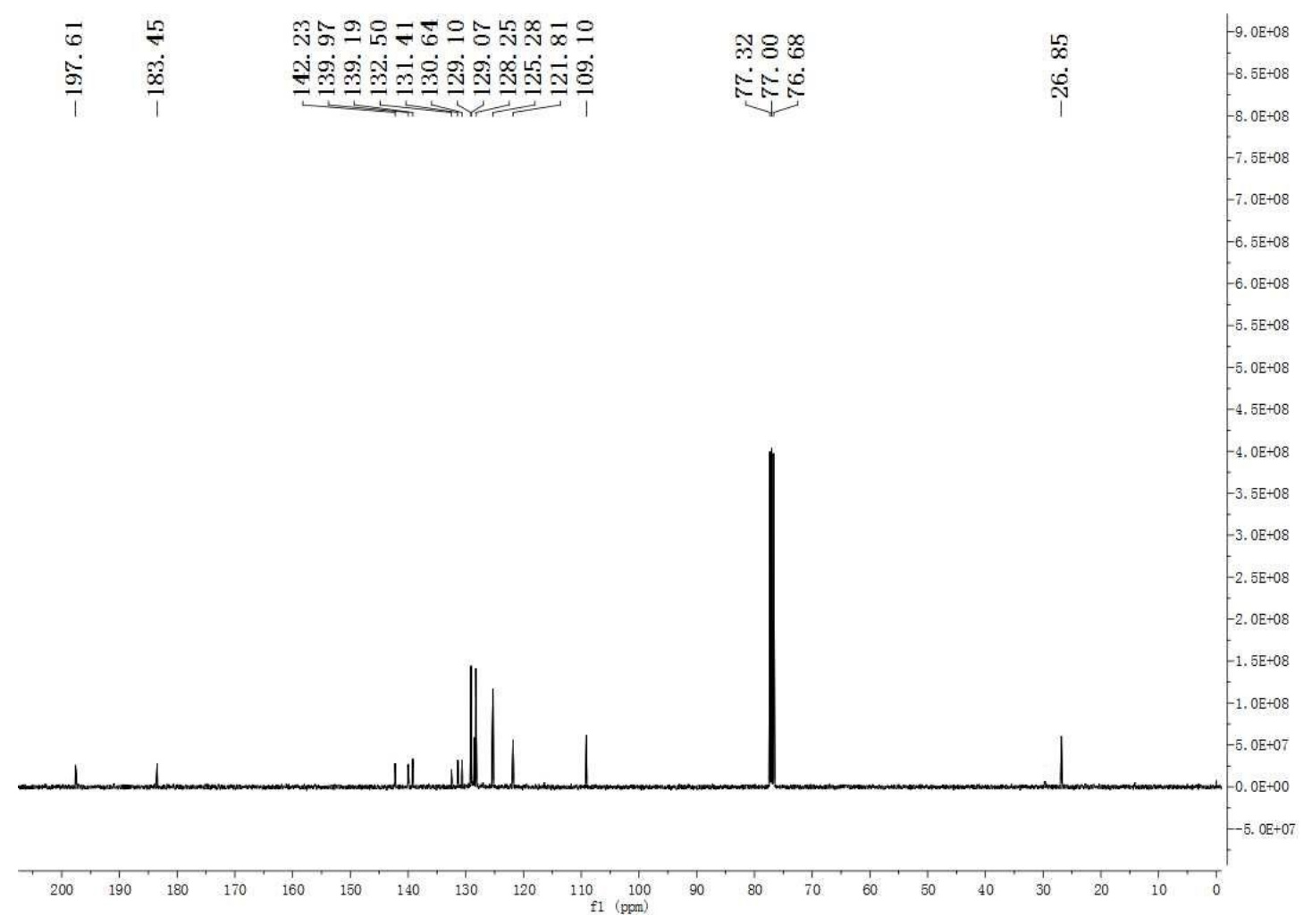

Figure S16. $100 \mathrm{MHz}{ }^{13} \mathrm{C}\left\{{ }^{1} \mathrm{H}\right\}$ NMR spectrum of $\mathbf{3 h}$ in $\mathrm{CDCl}_{3}$. 


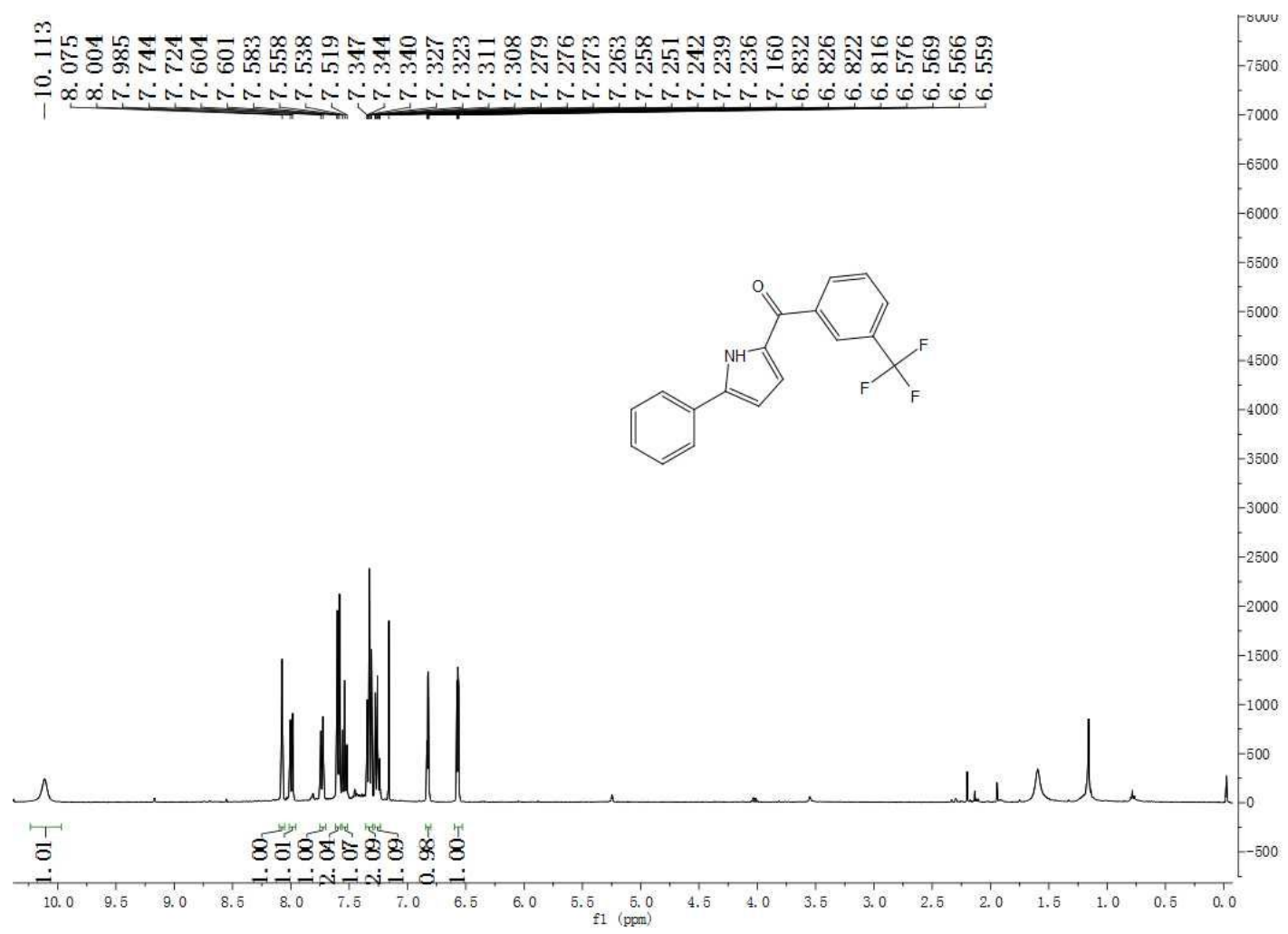

Figure S17. $400 \mathrm{MHz}{ }^{1} \mathrm{H}$ NMR spectrum of $3 \mathbf{i}$ in $\mathrm{CDCl}_{3}$

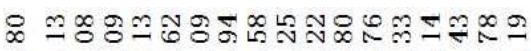

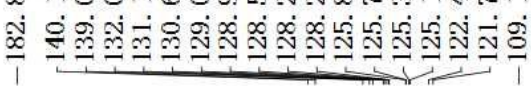

ले8:

쇼

6. $0 \mathrm{E}+08$

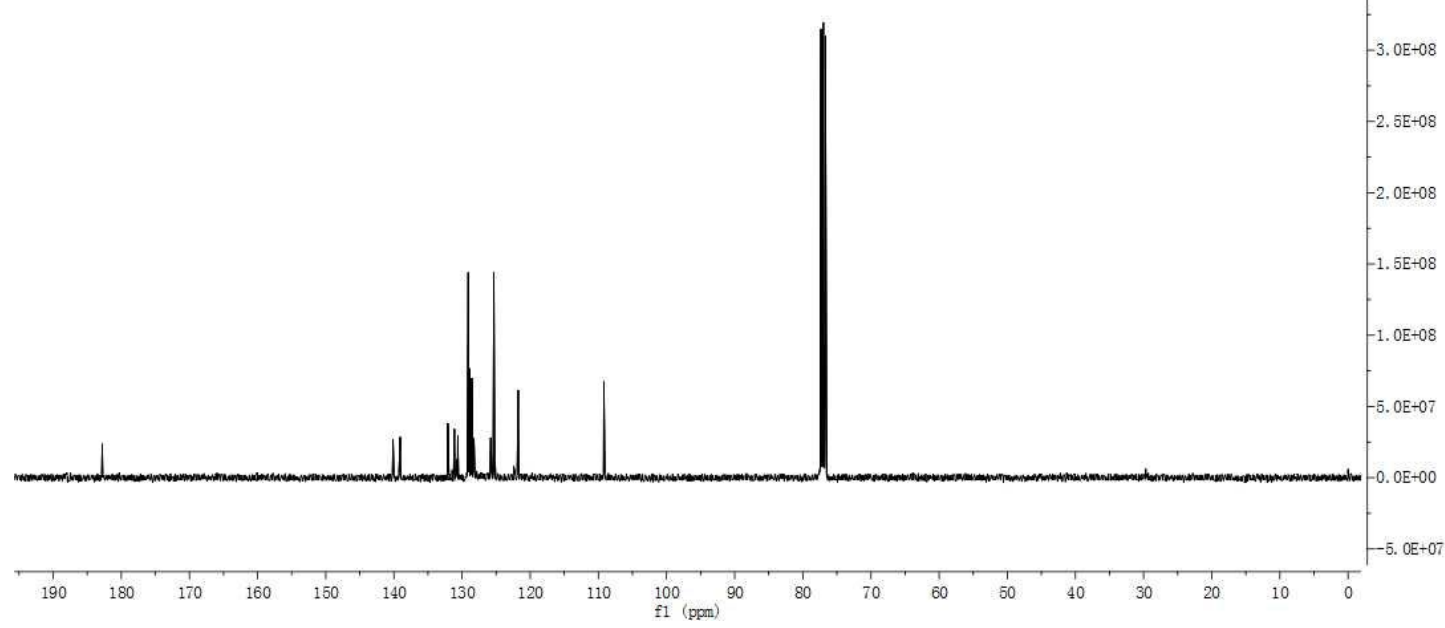

Figure S18. $100 \mathrm{MHz}{ }^{13} \mathrm{C}\left\{{ }^{1} \mathrm{H}\right\} \mathrm{NMR}$ spectrum of $\mathbf{3 i}$ in $\mathrm{CDCl}_{3}$. 


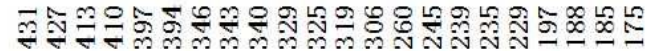

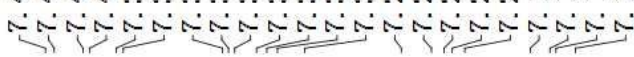
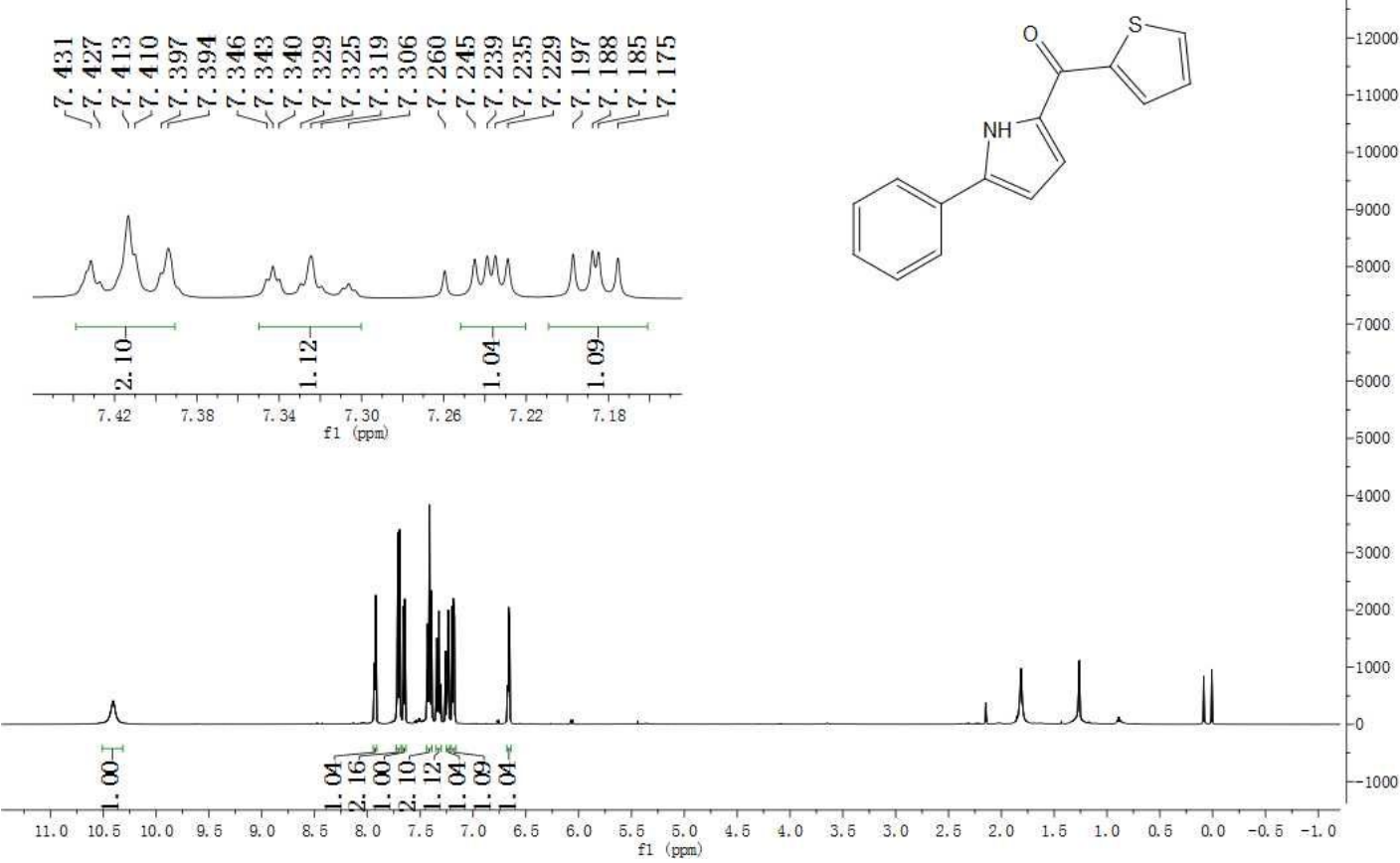

Figure S19. $400 \mathrm{MHz}{ }^{1} \mathrm{H}$ NMR spectrum of $\mathbf{3 j}$ in $\mathrm{CDCl}_{3}$

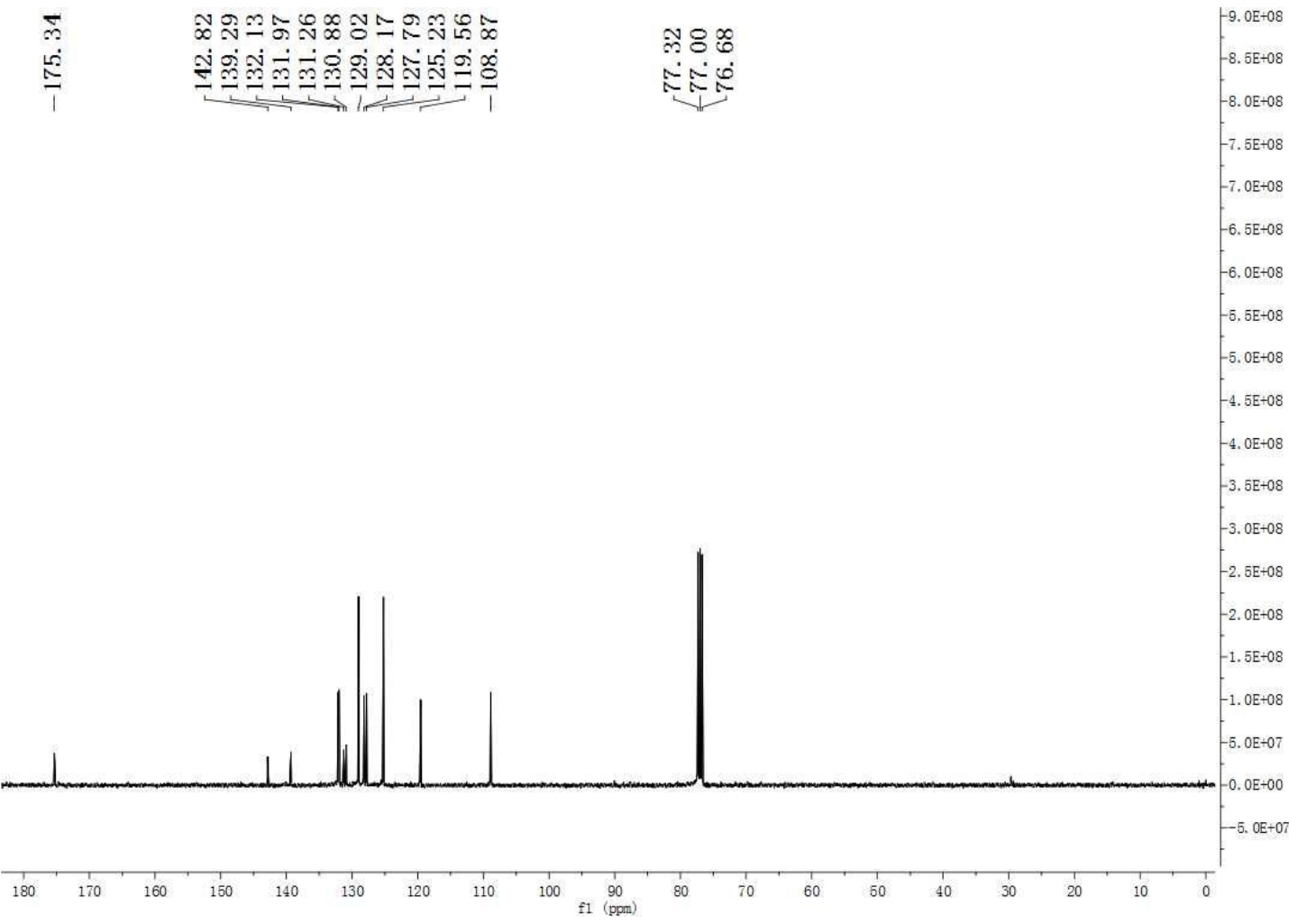

Figure S20. $100 \mathrm{MHz}{ }^{13} \mathrm{C}\left\{{ }^{1} \mathrm{H}\right\}$ NMR spectrum of $\mathbf{3 j}$ in $\mathrm{CDCl}_{3}$. 


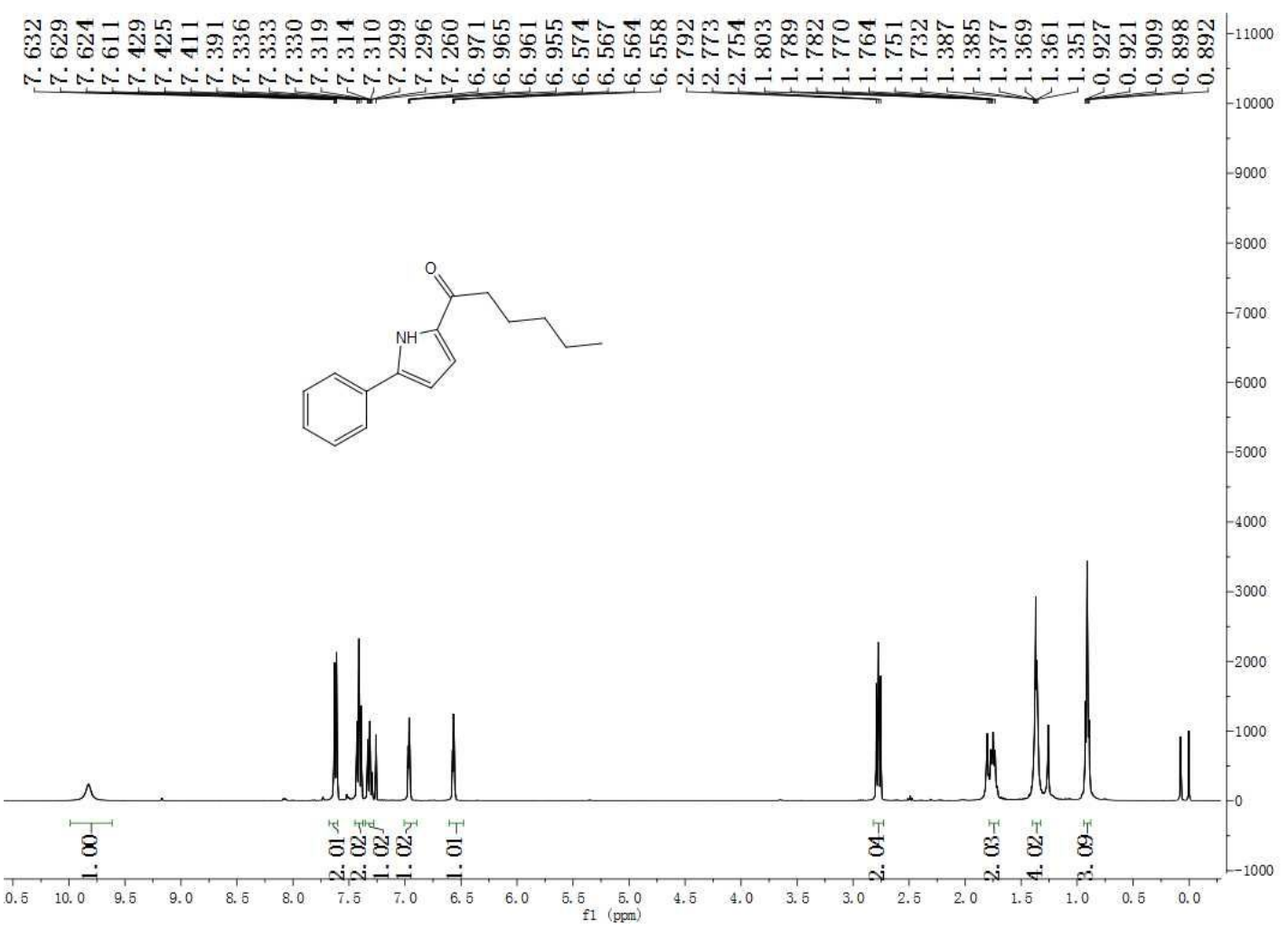

Figure S21. $400 \mathrm{MHz}{ }^{1} \mathrm{H} \mathrm{NMR}$ spectrum of 3k in $\mathrm{CDCl}_{3}$

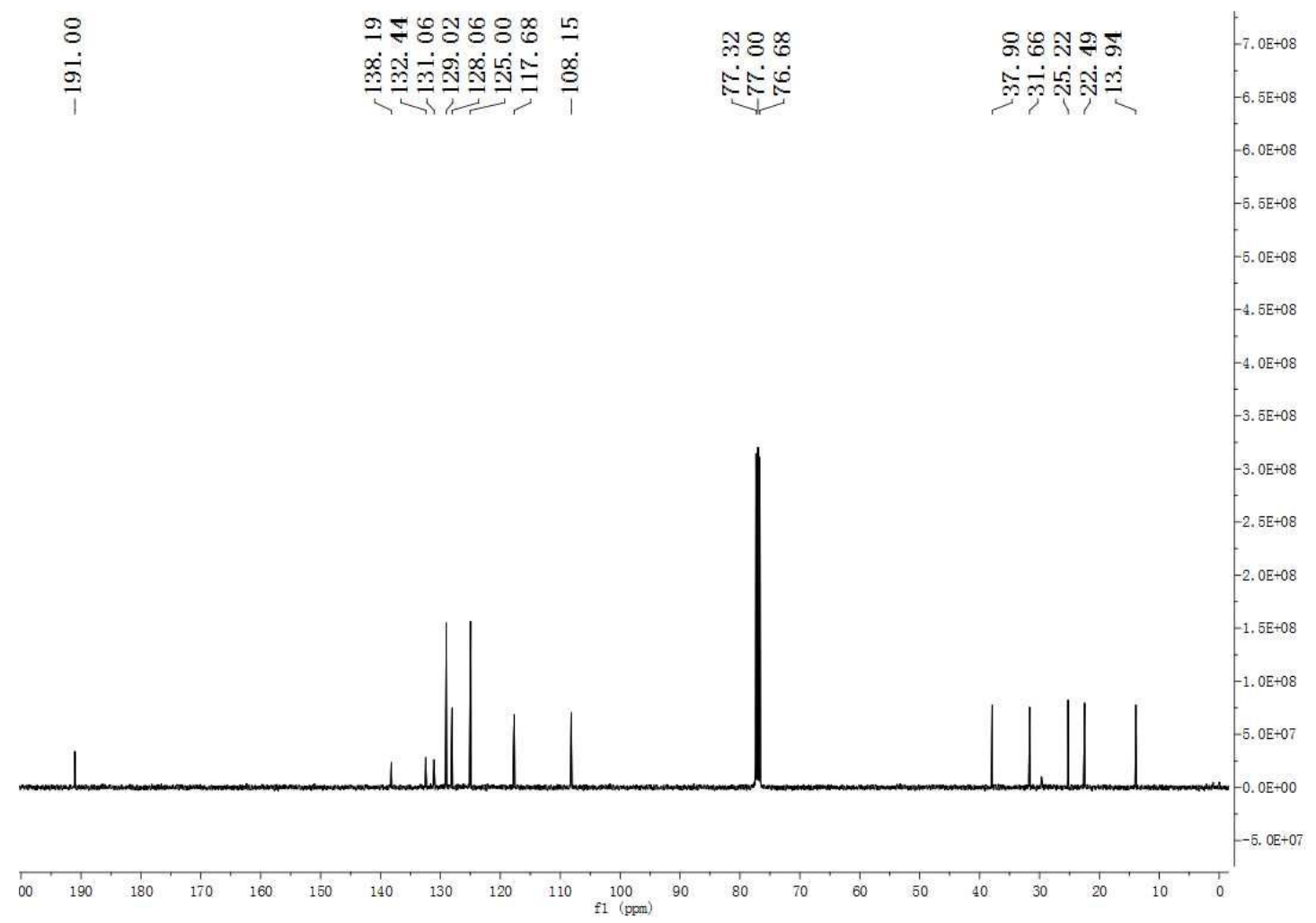

Figure S22. $100 \mathrm{MHz}{ }^{13} \mathrm{C}\left\{{ }^{1} \mathrm{H}\right\}$ NMR spectrum of $\mathbf{3 k}$ in $\mathrm{CDCl}_{3}$. 


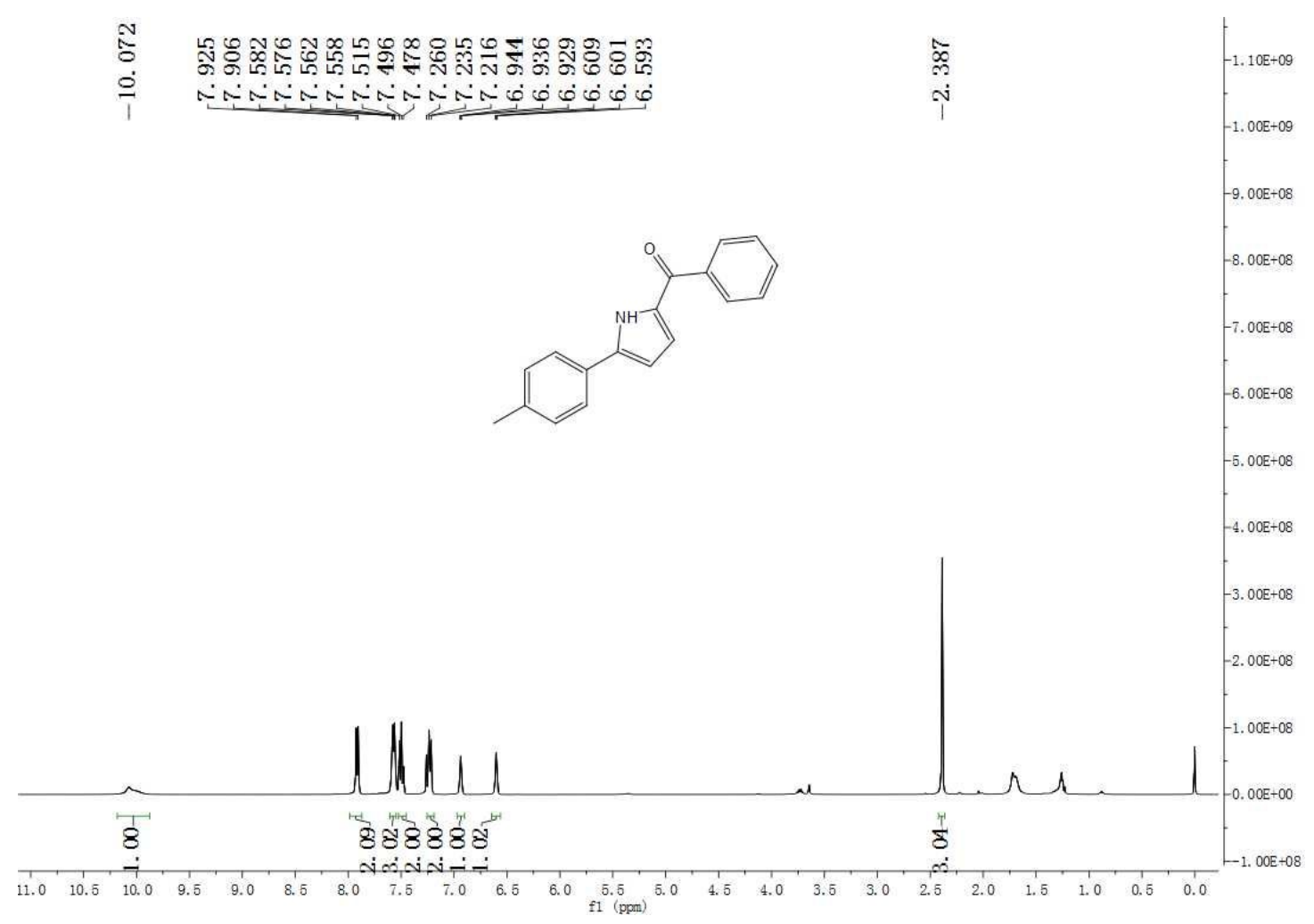

Figure S23. $400 \mathrm{MHz}^{1} \mathrm{H}$ NMR spectrum of 31 in $\mathrm{CDCl}_{3}$

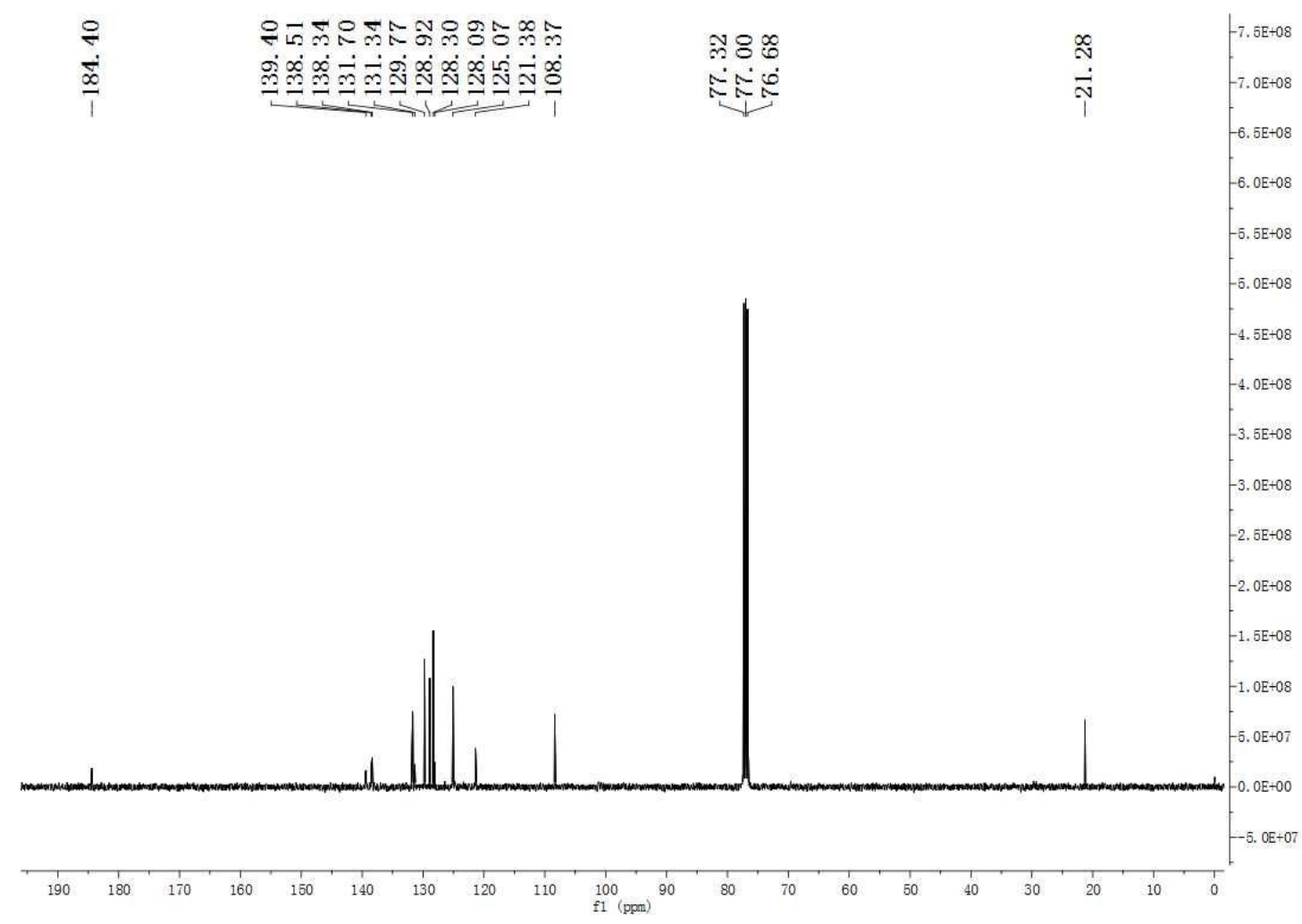

Figure S24. $100 \mathrm{MHz}{ }^{13} \mathrm{C}\left\{{ }^{1} \mathrm{H}\right\} \mathrm{NMR}$ spectrum of $\mathbf{3 l}$ in $\mathrm{CDCl}_{3}$. 


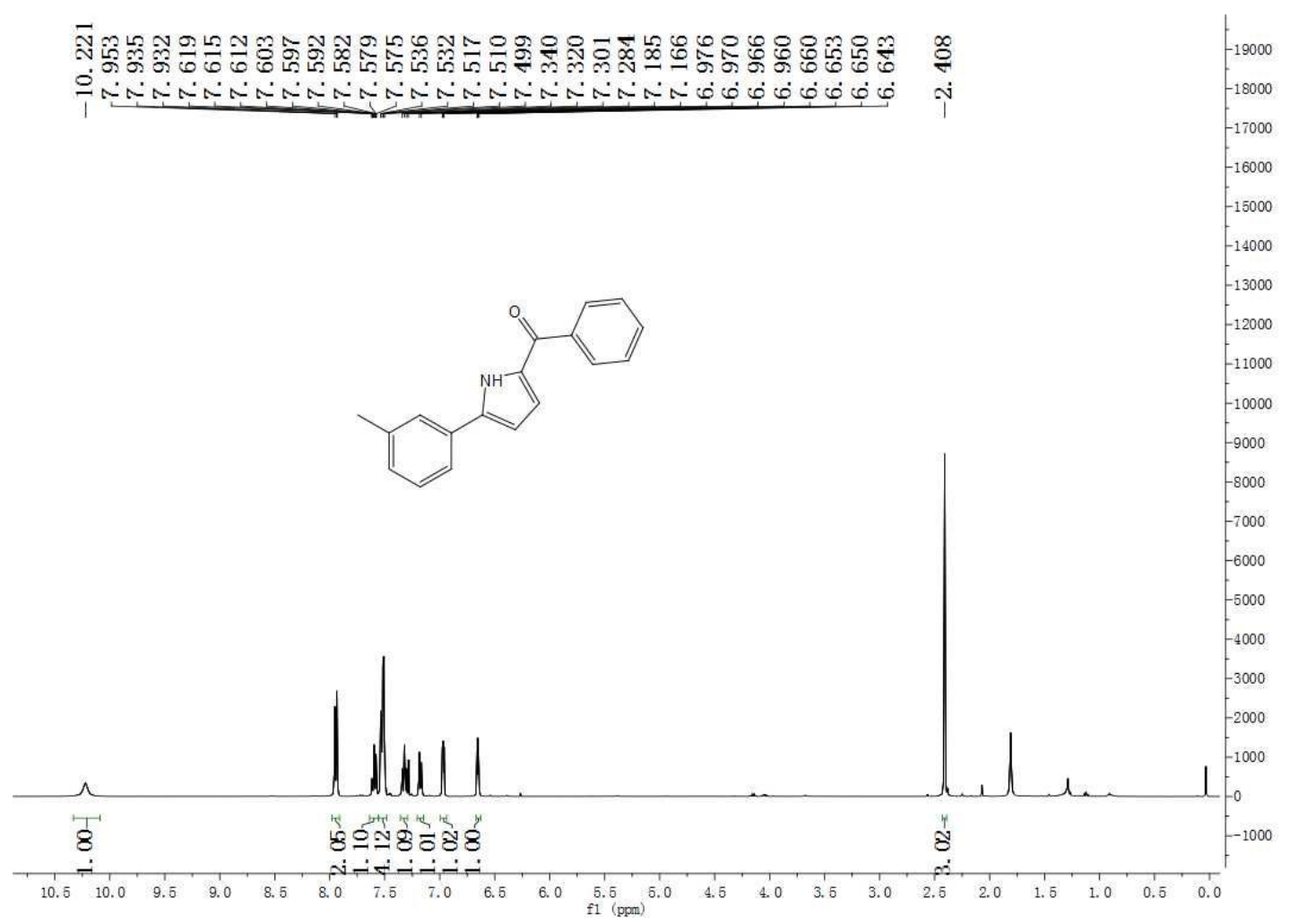

Figure S25. $400 \mathrm{MHz}{ }^{1} \mathrm{H}$ NMR spectrum of $\mathbf{3 m}$ in $\mathrm{CDCl}_{3}$

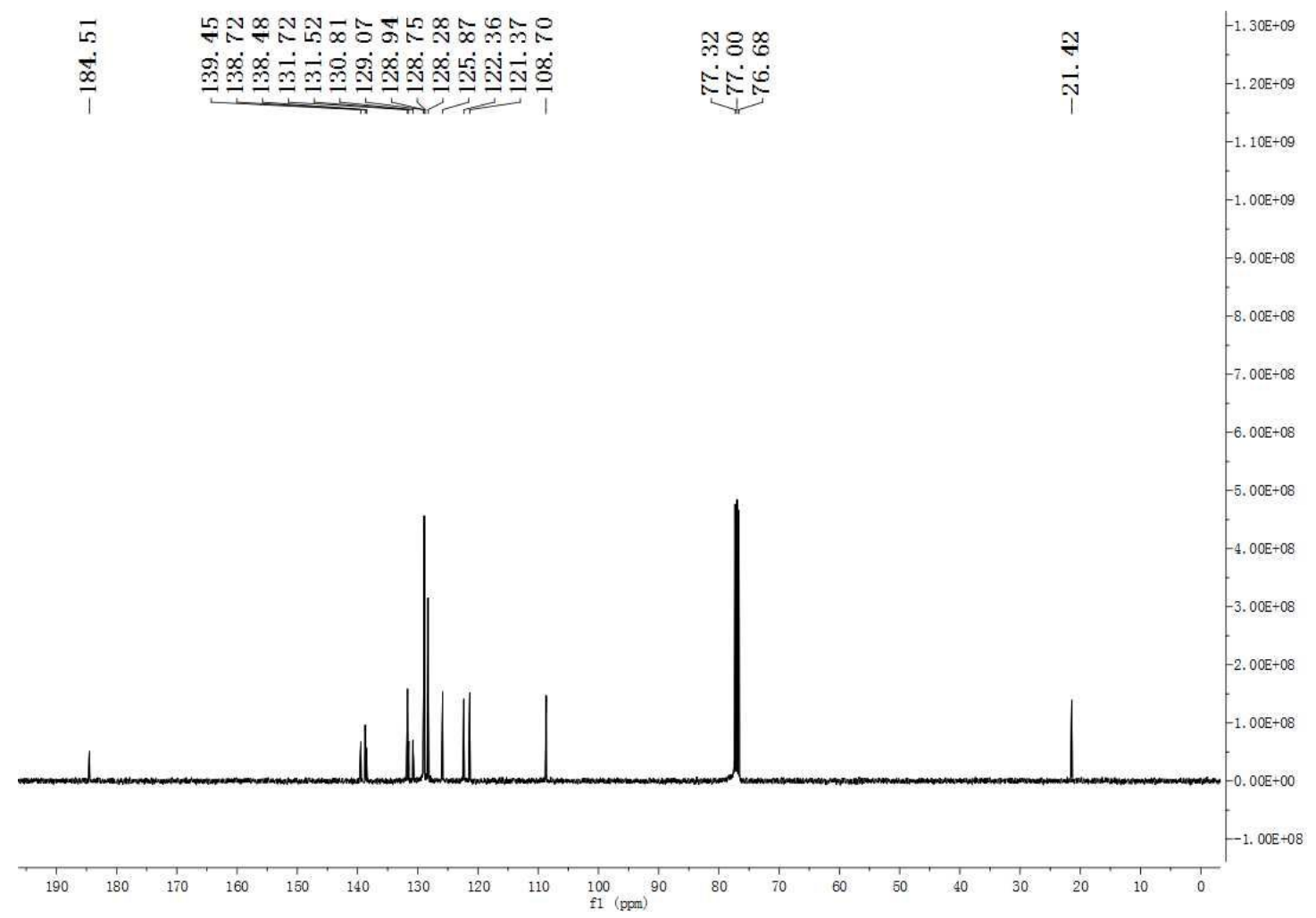

Figure S26. $100 \mathrm{MHz}{ }^{13} \mathrm{C}\left\{{ }^{1} \mathrm{H}\right\} \mathrm{NMR}$ spectrum of $\mathbf{3 m}$ in $\mathrm{CDCl}_{3}$. 


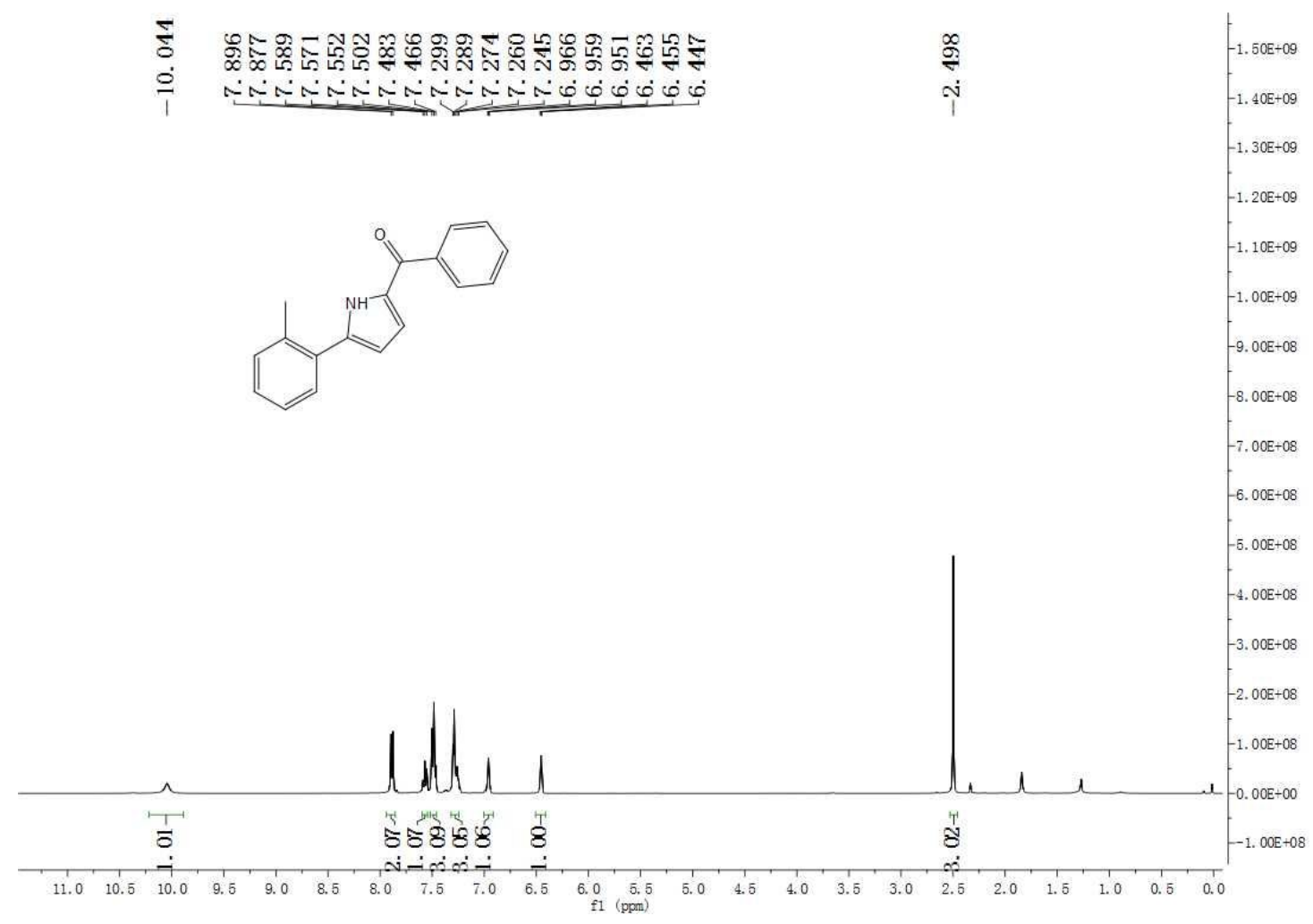

Figure S27. $400 \mathrm{MHz}{ }^{1} \mathrm{H}$ NMR spectrum of $\mathbf{3 n}$ in $\mathrm{CDCl}_{3}$

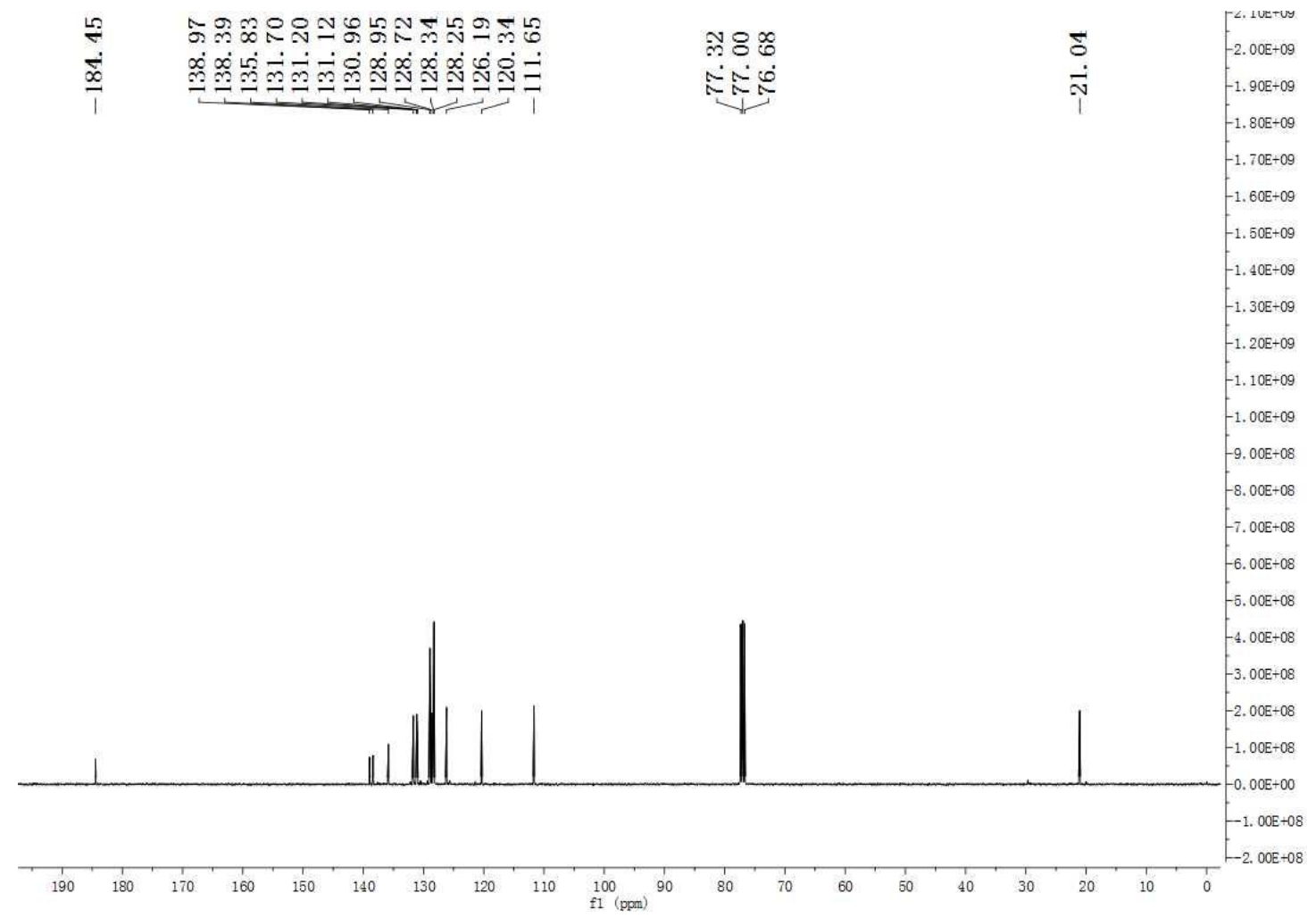

Figure S28. $100 \mathrm{MHz}{ }^{13} \mathrm{C}\left\{{ }^{1} \mathrm{H}\right\}$ NMR spectrum of $\mathbf{3 n}$ in $\mathrm{CDCl}_{3}$. 


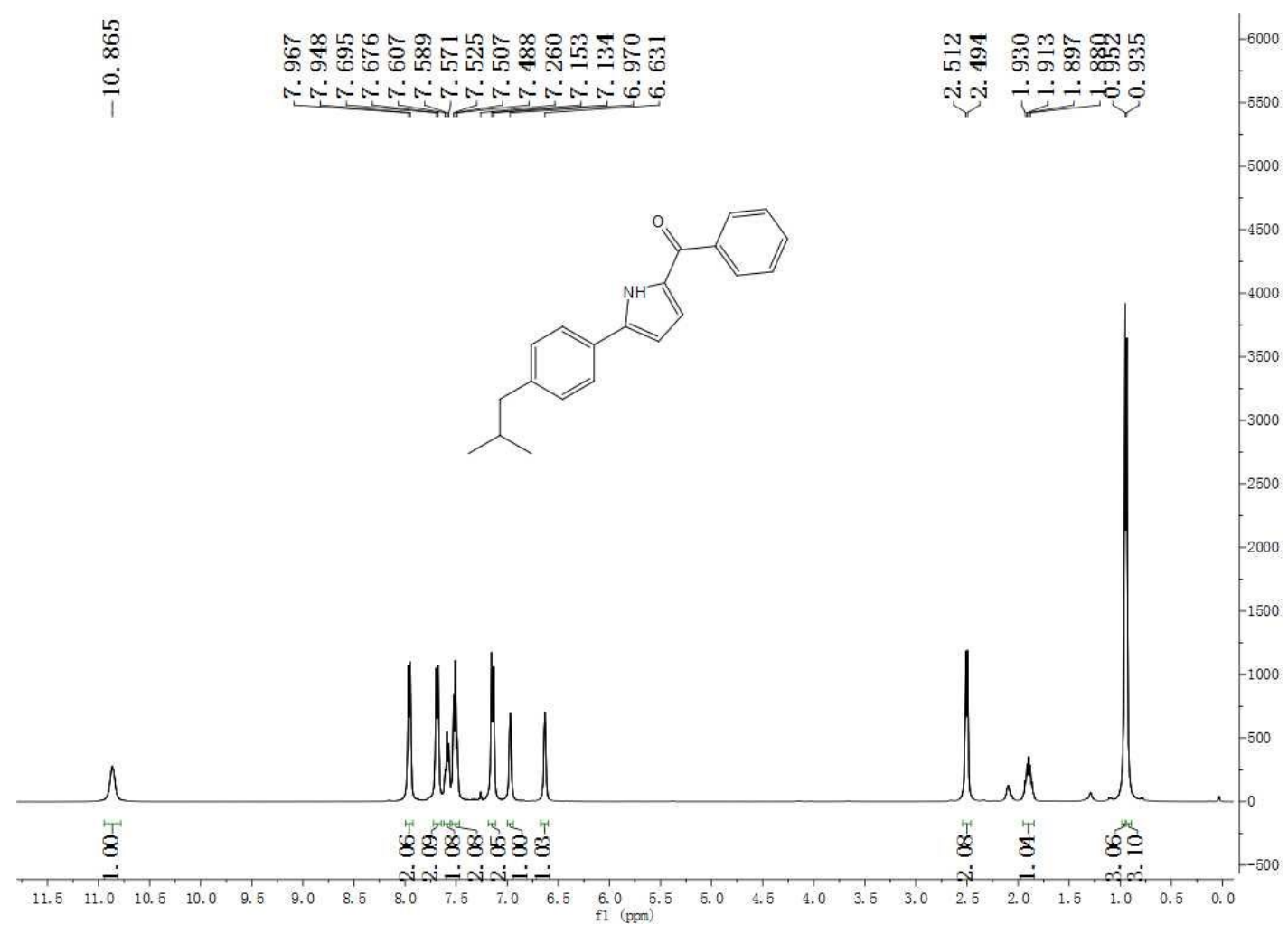

Figure S29. $400 \mathrm{MHz}{ }^{1} \mathrm{H}$ NMR spectrum of 30 in $\mathrm{CDCl}_{3}$

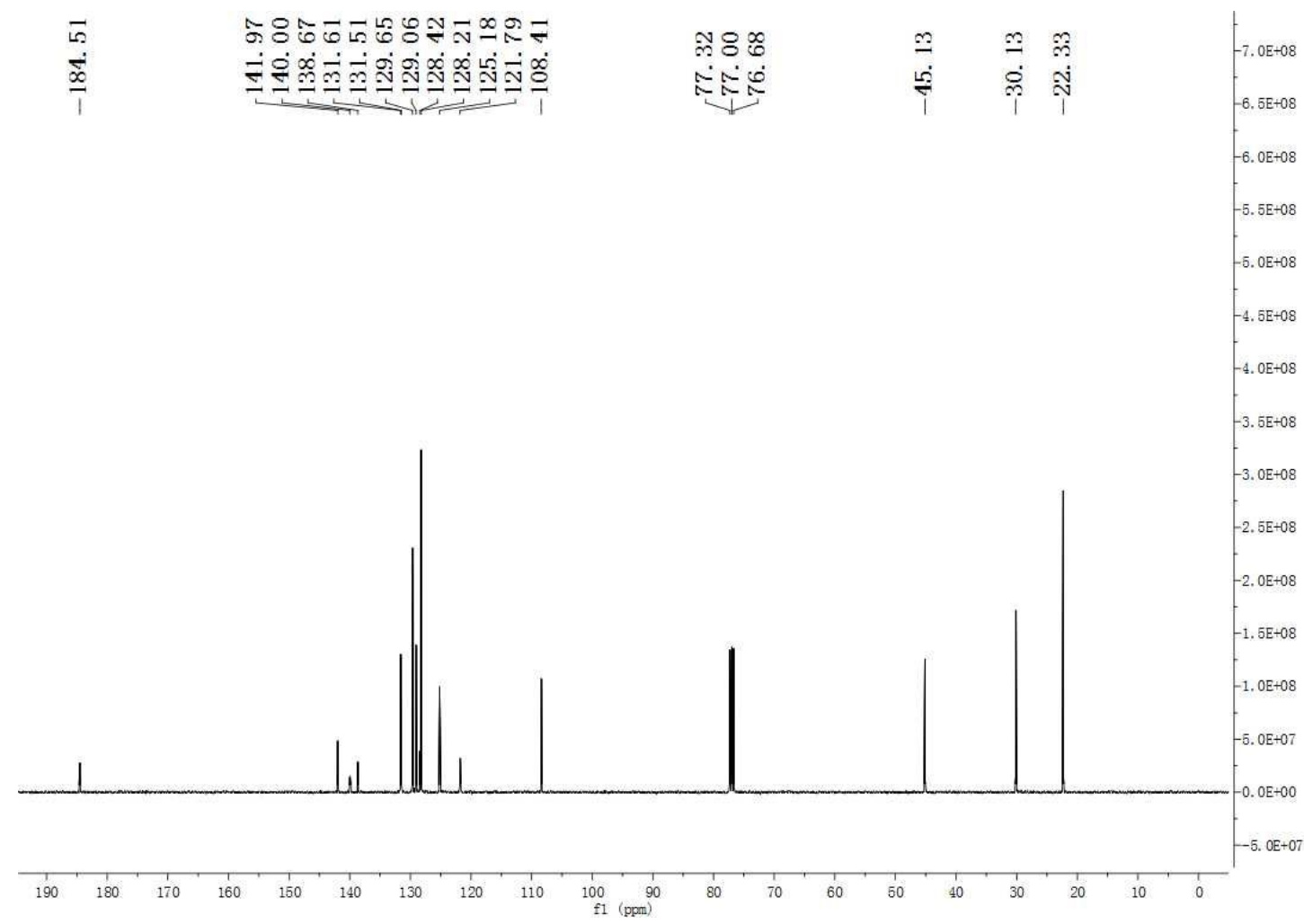

Figure S30. $100 \mathrm{MHz}{ }^{13} \mathrm{C}\left\{{ }^{1} \mathrm{H}\right\}$ NMR spectrum of 3o in $\mathrm{CDCl}_{3}$. 


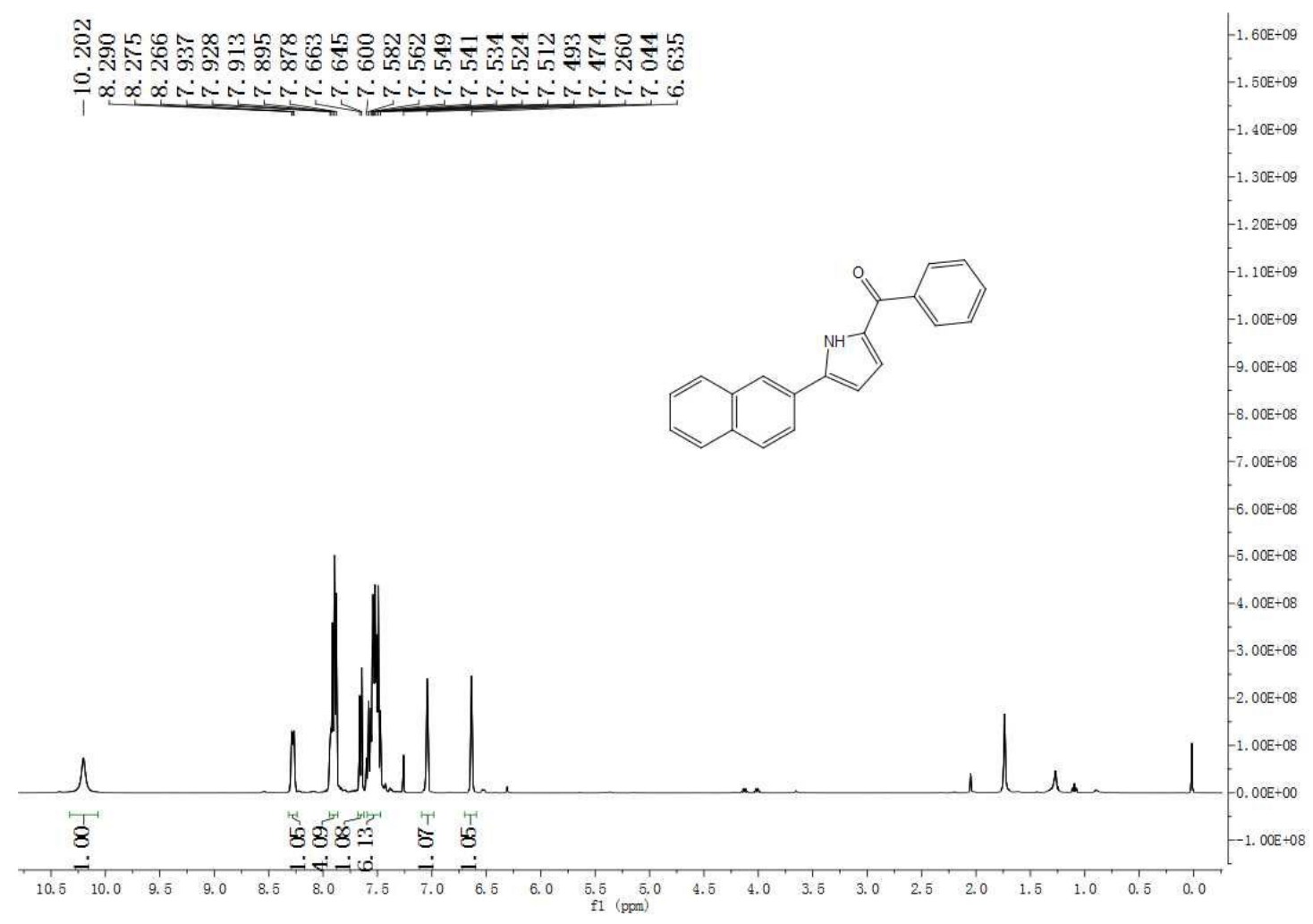

Figure S31. $400 \mathrm{MHz}{ }^{1} \mathrm{H}$ NMR spectrum of 3p in $\mathrm{CDCl}_{3}$

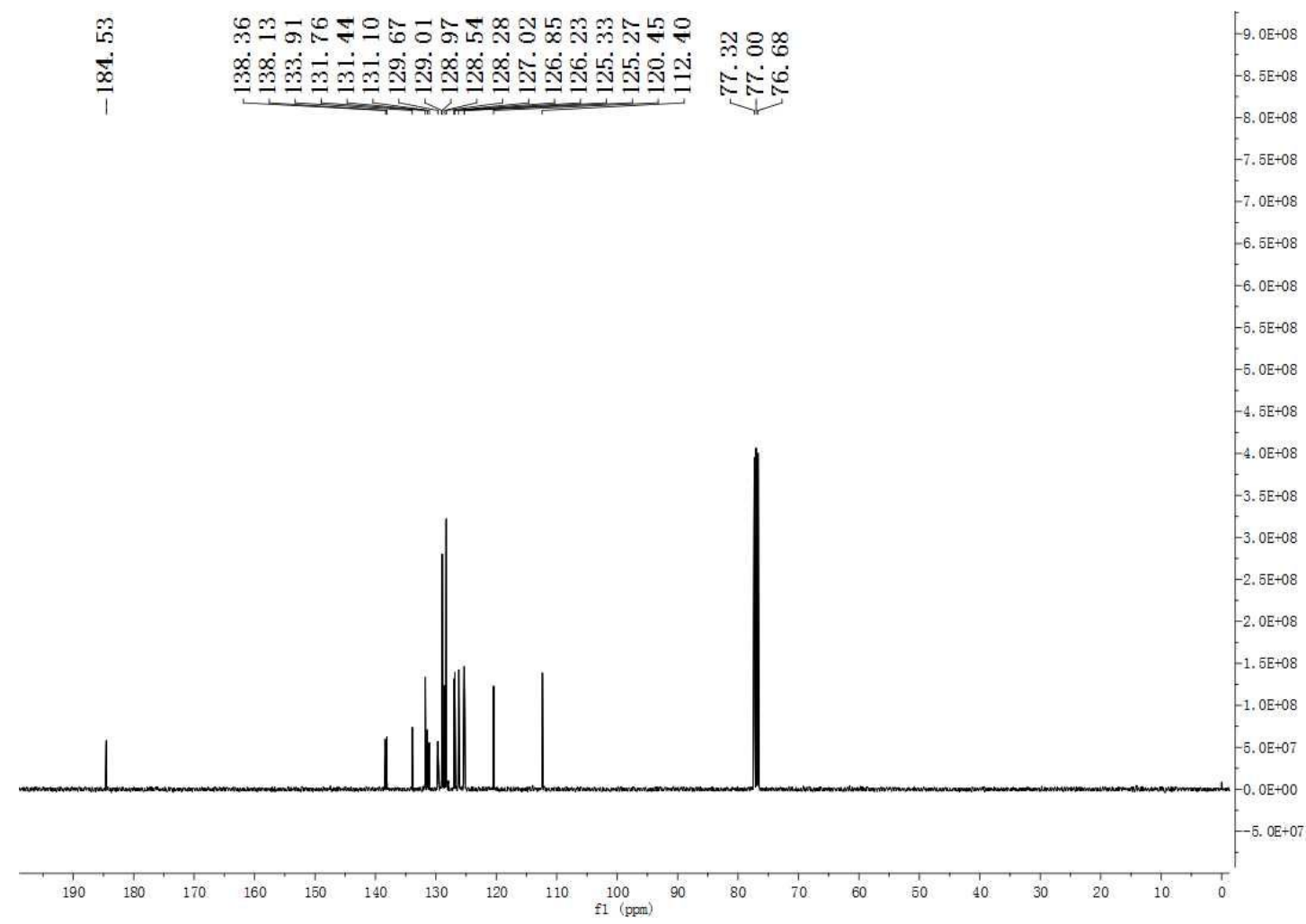

Figure S32. $100 \mathrm{MHz}{ }^{13} \mathrm{C}\left\{{ }^{1} \mathrm{H}\right\}$ NMR spectrum of $\mathbf{3 p}$ in $\mathrm{CDCl}_{3}$. 


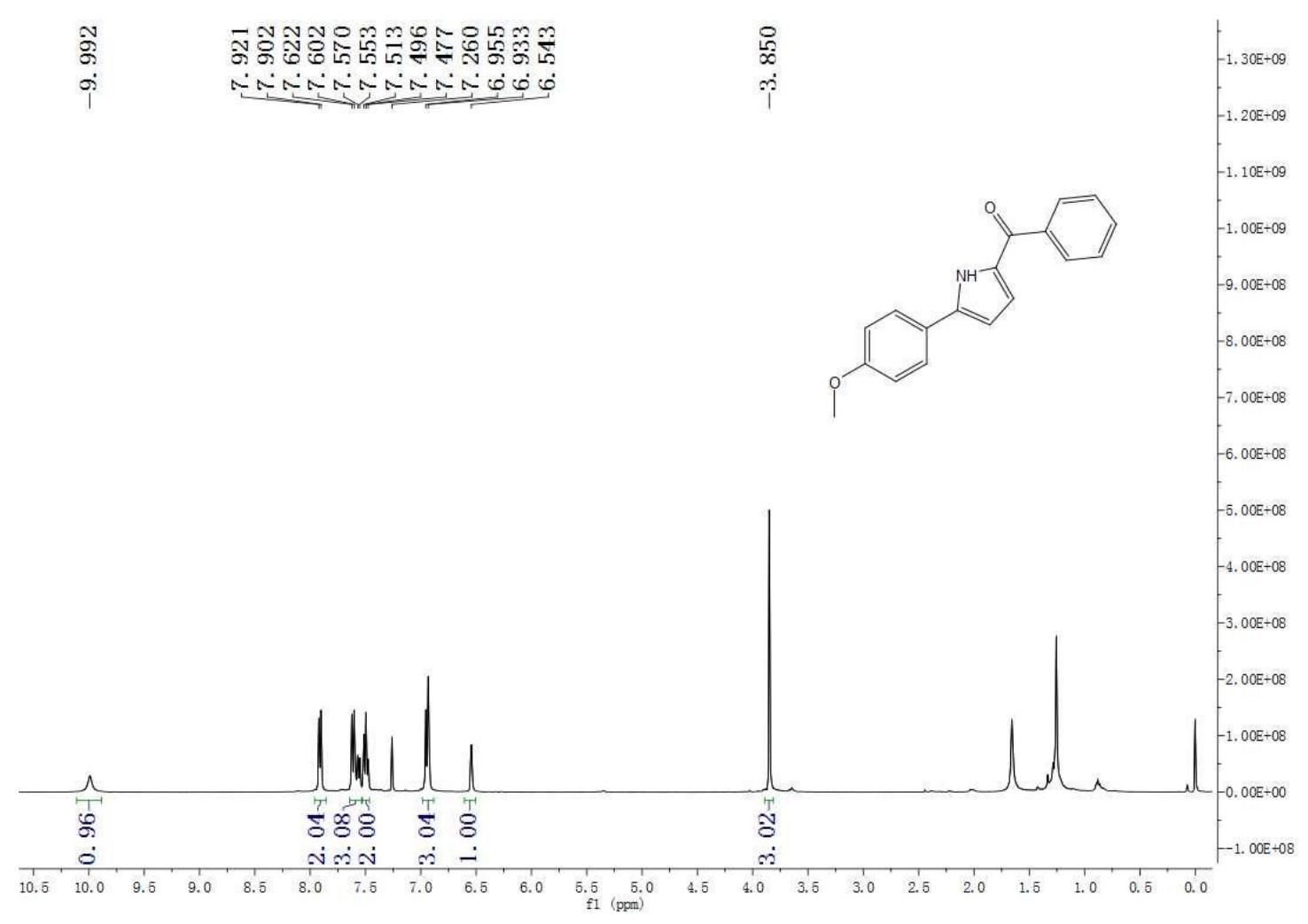

Figure S33. $400 \mathrm{MHz}{ }^{1} \mathrm{H}$ NMR spectrum of $\mathbf{3 q}$ in $\mathrm{CDCl}_{3}$

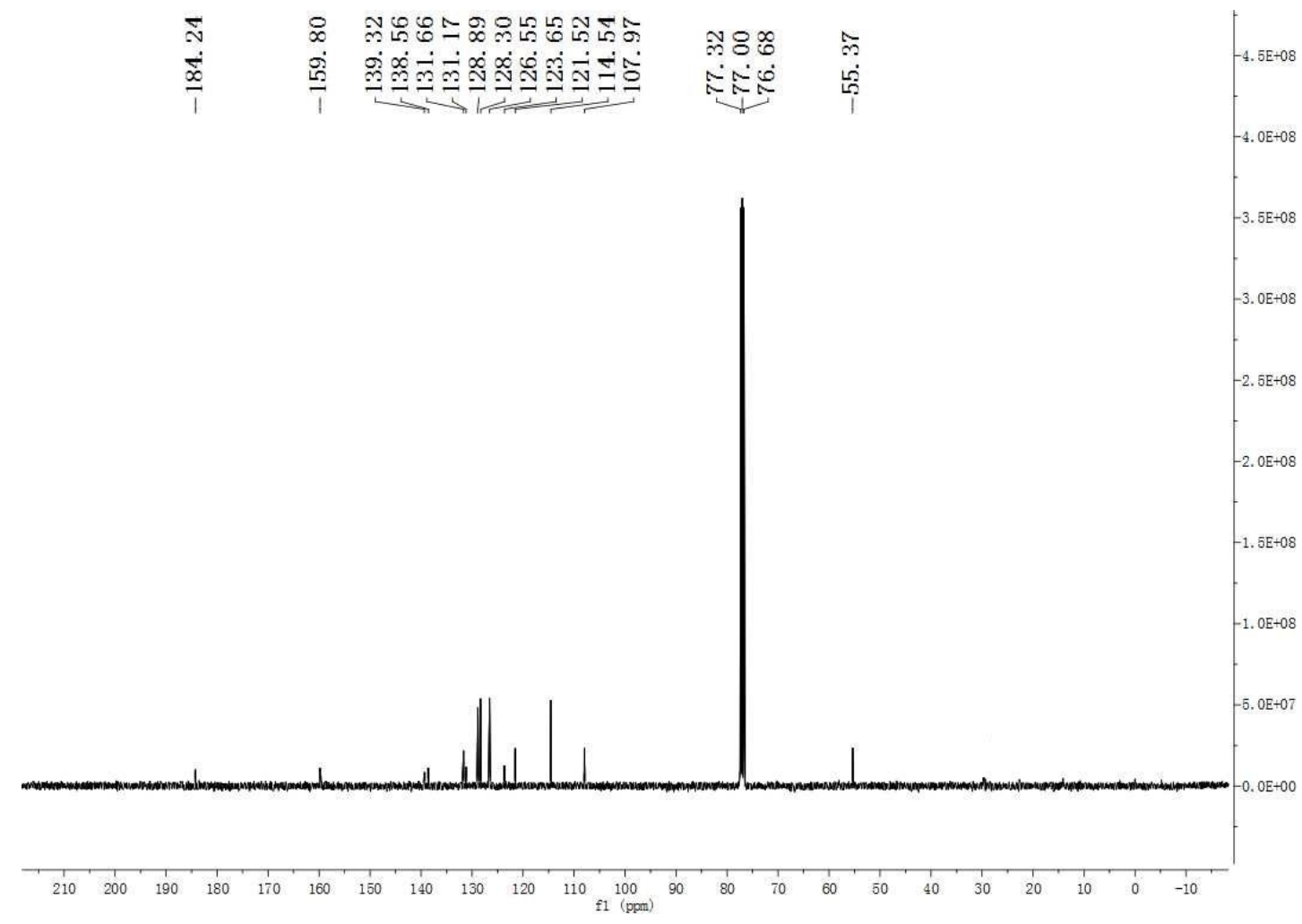

Figure S34. $100 \mathrm{MHz}{ }^{13} \mathrm{C}\left\{{ }^{1} \mathrm{H}\right\}$ NMR spectrum of $\mathbf{3 q}$ in $\mathrm{CDCl}_{3}$. 


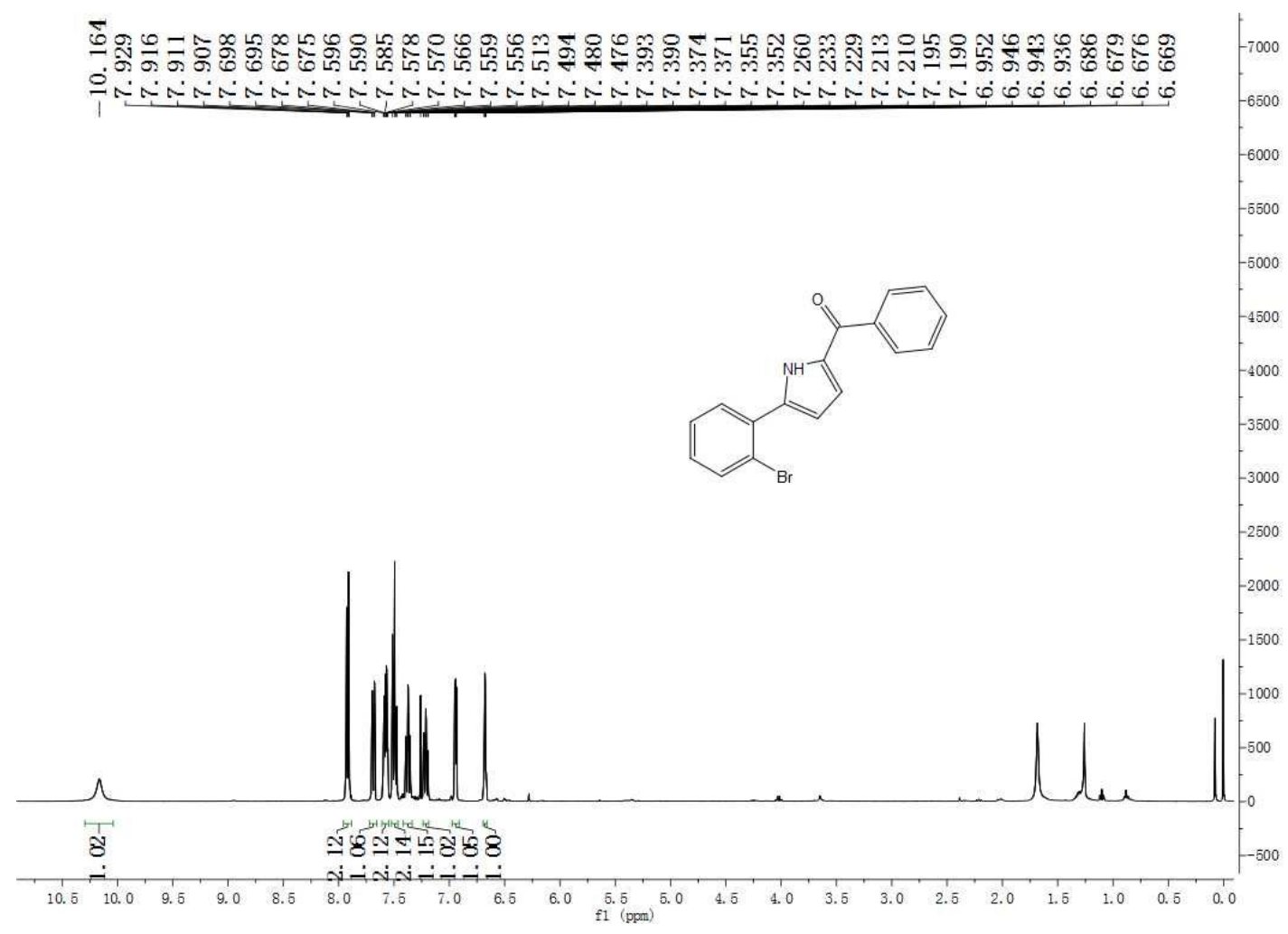

Figure S35. $400 \mathrm{MHz}{ }^{1} \mathrm{H}$ NMR spectrum of $\mathbf{3 r}$ in $\mathrm{CDCl}_{3}$

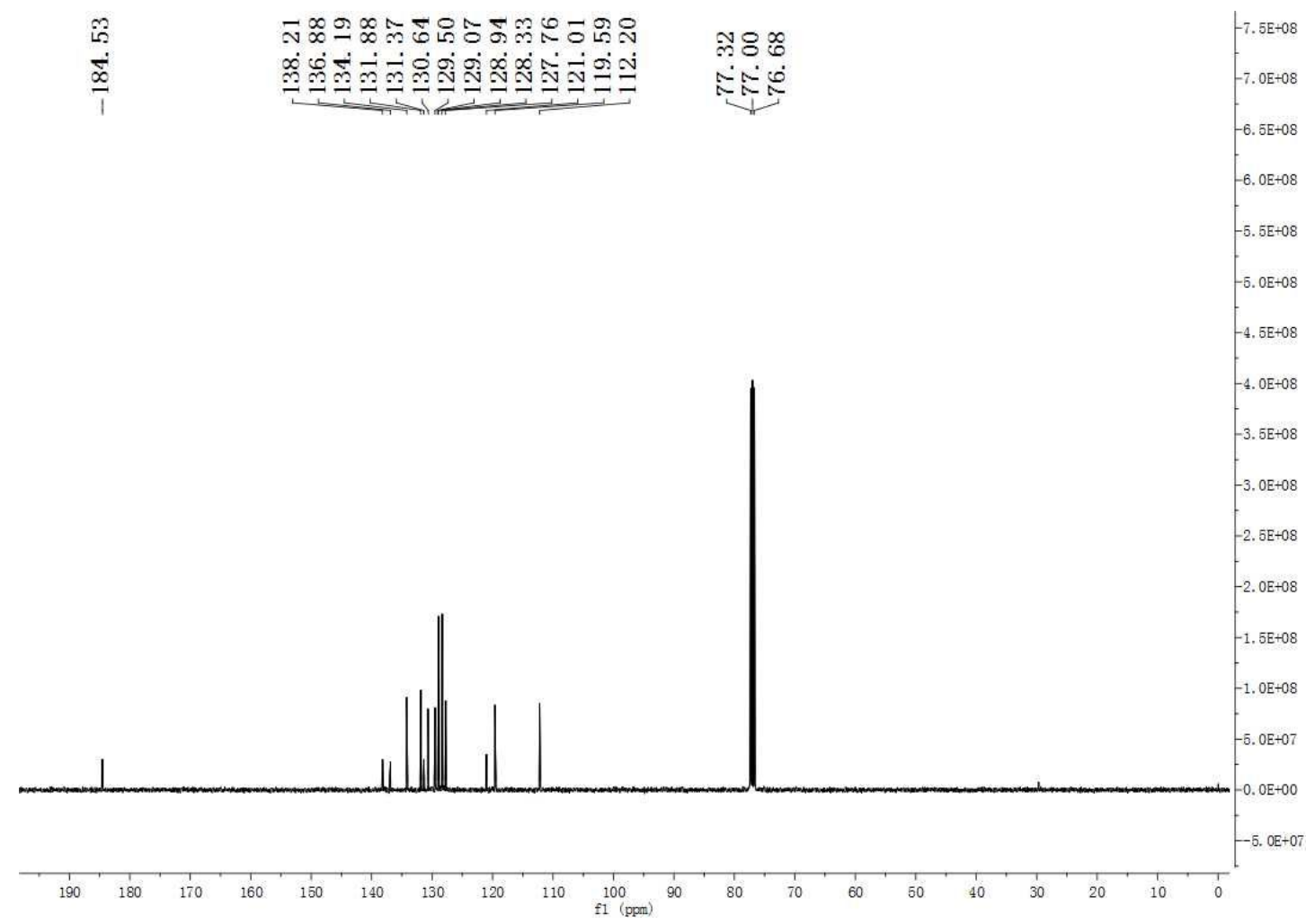

Figure S36. $100 \mathrm{MHz}{ }^{13} \mathrm{C}\left\{{ }^{1} \mathrm{H}\right\}$ NMR spectrum of $3 \mathbf{r}$ in $\mathrm{CDCl}_{3}$. 


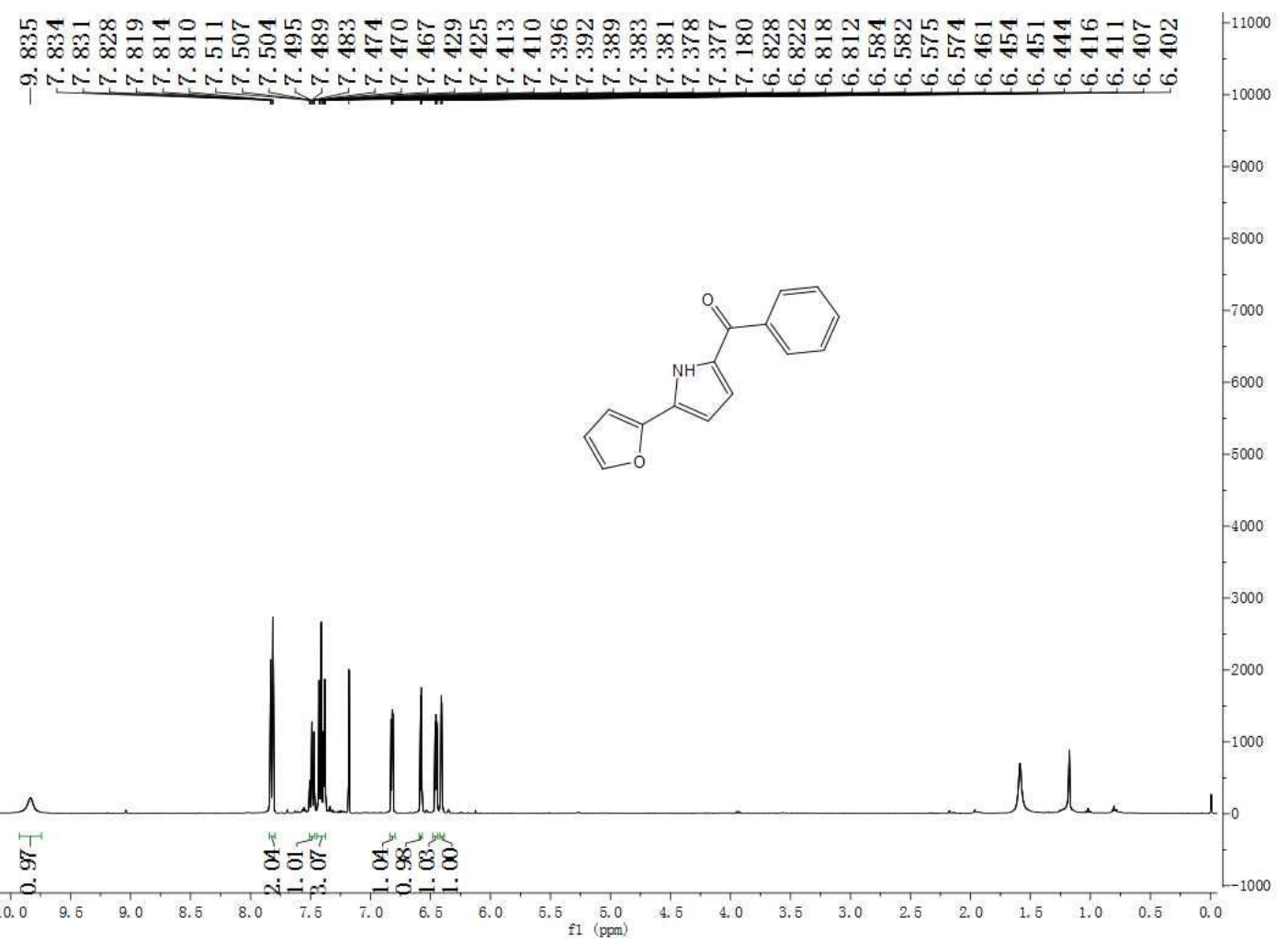

Figure S37. $400 \mathrm{MHz}{ }^{1} \mathrm{H}$ NMR spectrum of $3 \mathrm{~s}$ in $\mathrm{CDCl}_{3}$

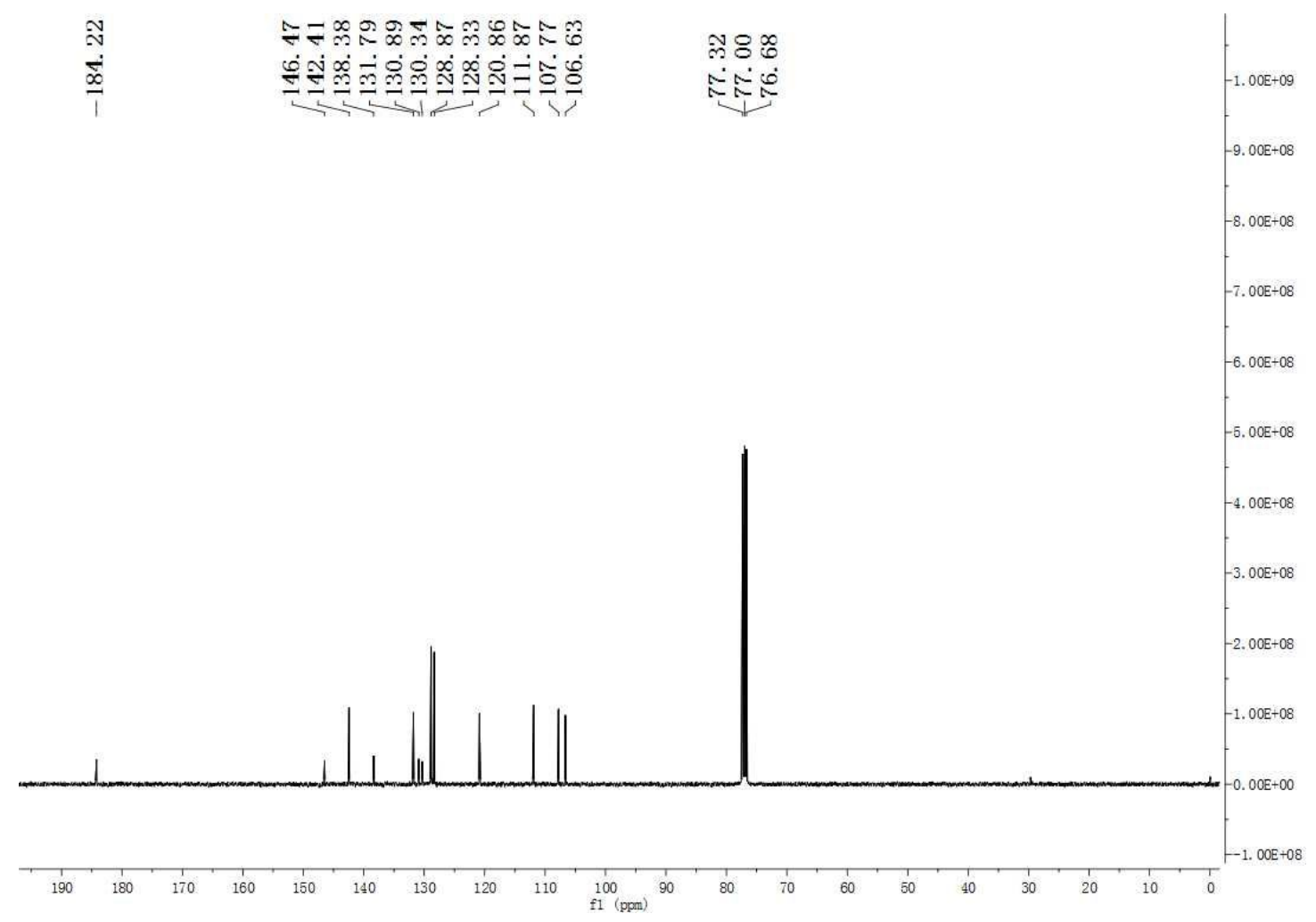

Figure S38. $100 \mathrm{MHz}{ }^{13} \mathrm{C}\left\{{ }^{1} \mathrm{H}\right\}$ NMR spectrum of $\mathbf{3 s}$ in $\mathrm{CDCl}_{3}$. 


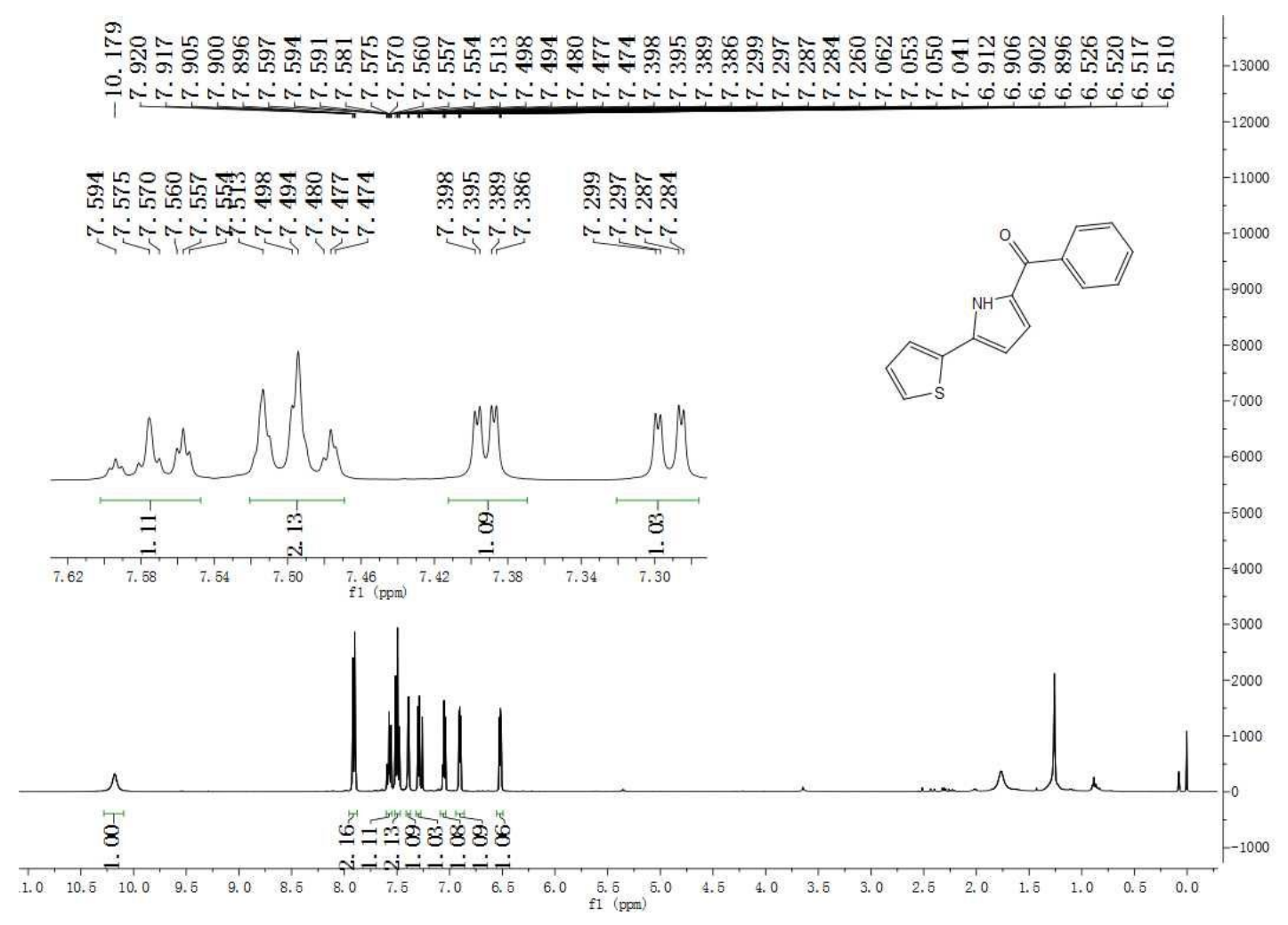

Figure S39. $400 \mathrm{MHz}{ }^{1} \mathrm{H}$ NMR spectrum of 3t in $\mathrm{CDCl}_{3}$

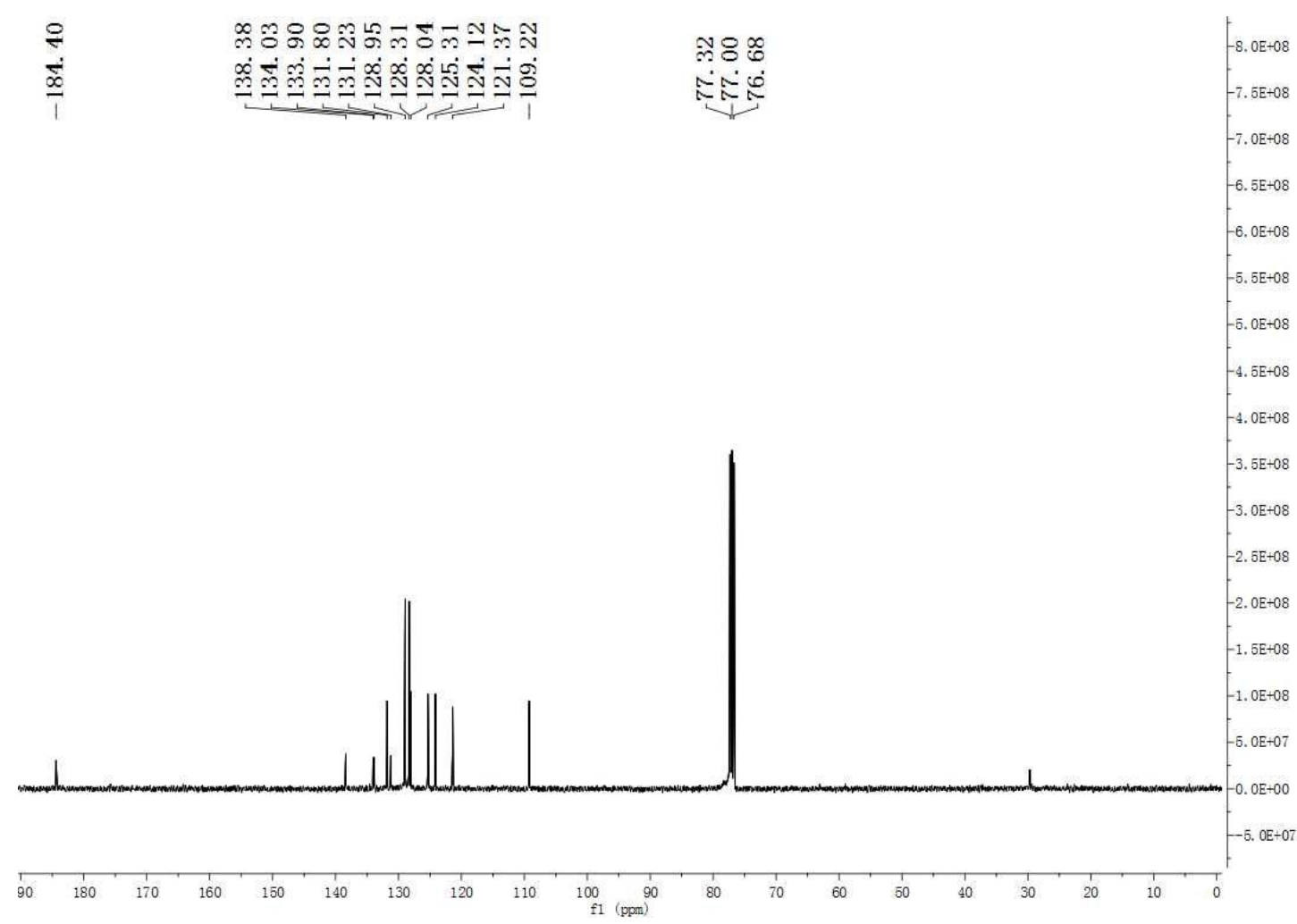

Figure S40. $100 \mathrm{MHz}{ }^{13} \mathrm{C}\left\{{ }^{1} \mathrm{H}\right\}$ NMR spectrum of $\mathbf{3 t}$ in $\mathrm{CDCl}_{3}$. 


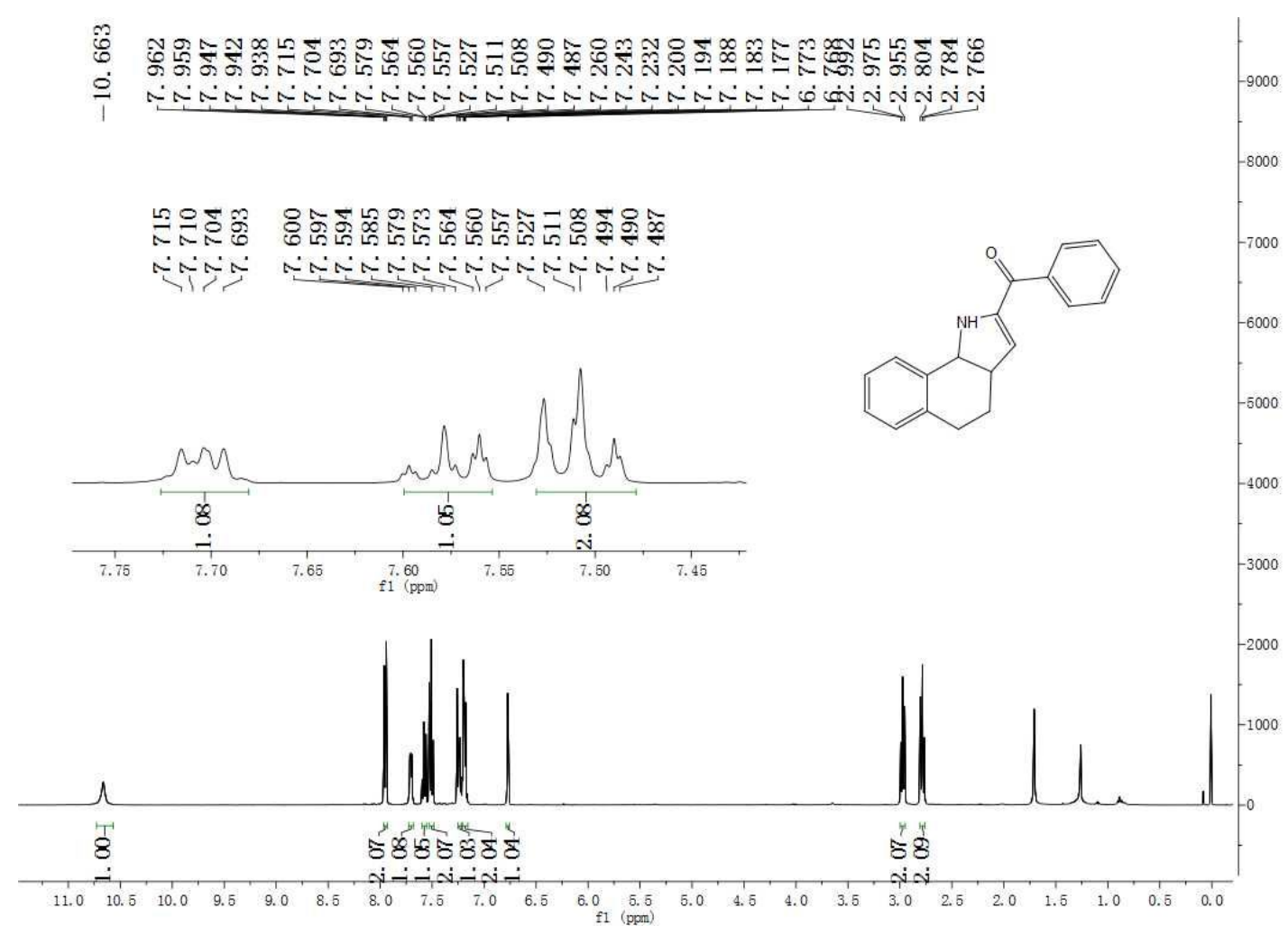

Figure S41. $400 \mathrm{MHz}{ }^{1} \mathrm{H}$ NMR spectrum of $\mathbf{3 u}$ in $\mathrm{CDCl}_{3}$

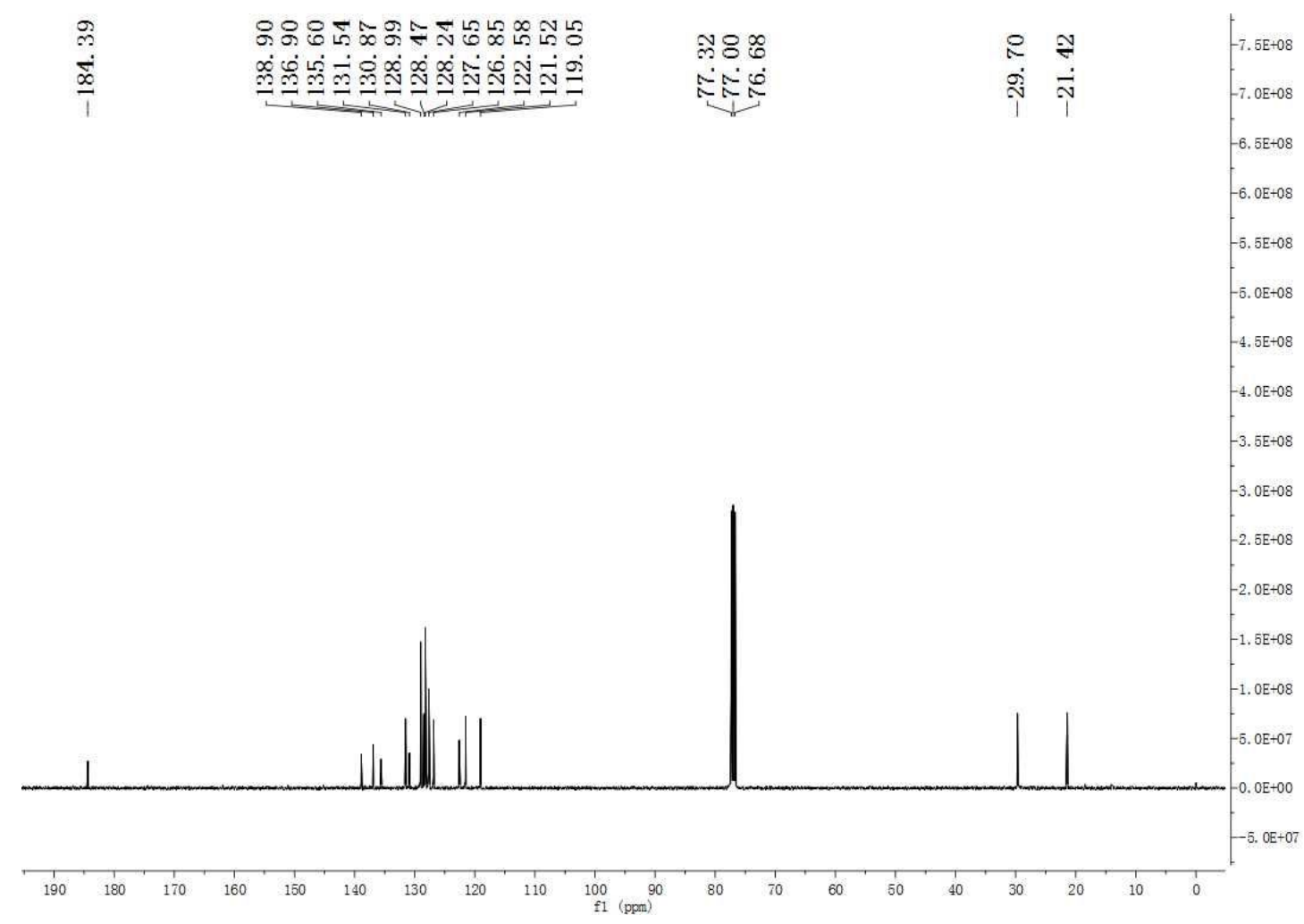

Figure $\mathbf{S 4 2} .100 \mathrm{MHz}{ }^{13} \mathrm{C}\left\{{ }^{1} \mathrm{H}\right\}$ NMR spectrum of $\mathbf{3 u}$ in $\mathrm{CDCl}_{3}$. 


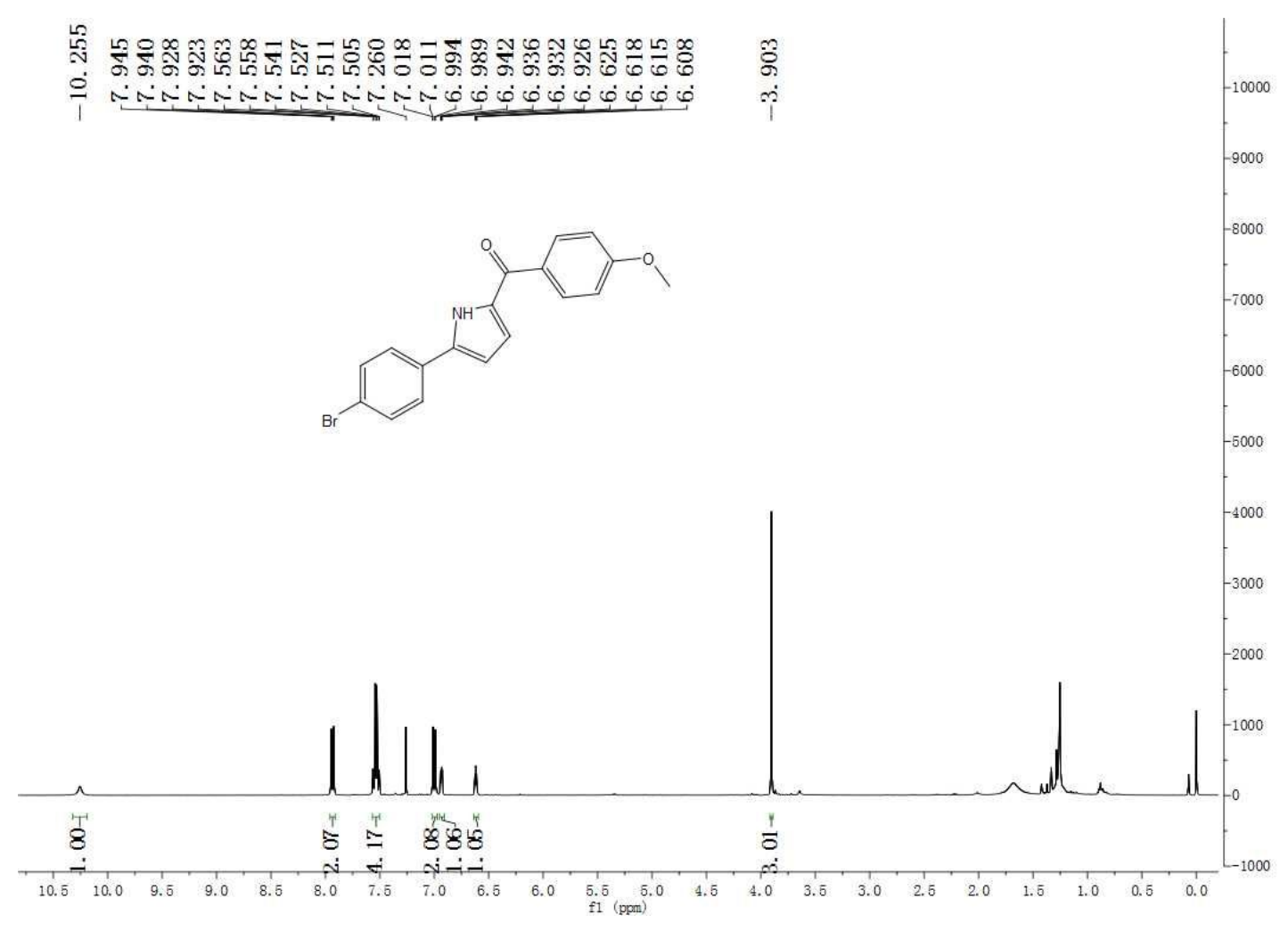

Figure S43. $400 \mathrm{MHz}{ }^{1} \mathrm{H}$ NMR spectrum of $\mathbf{3 v}$ in $\mathrm{CDCl}_{3}$

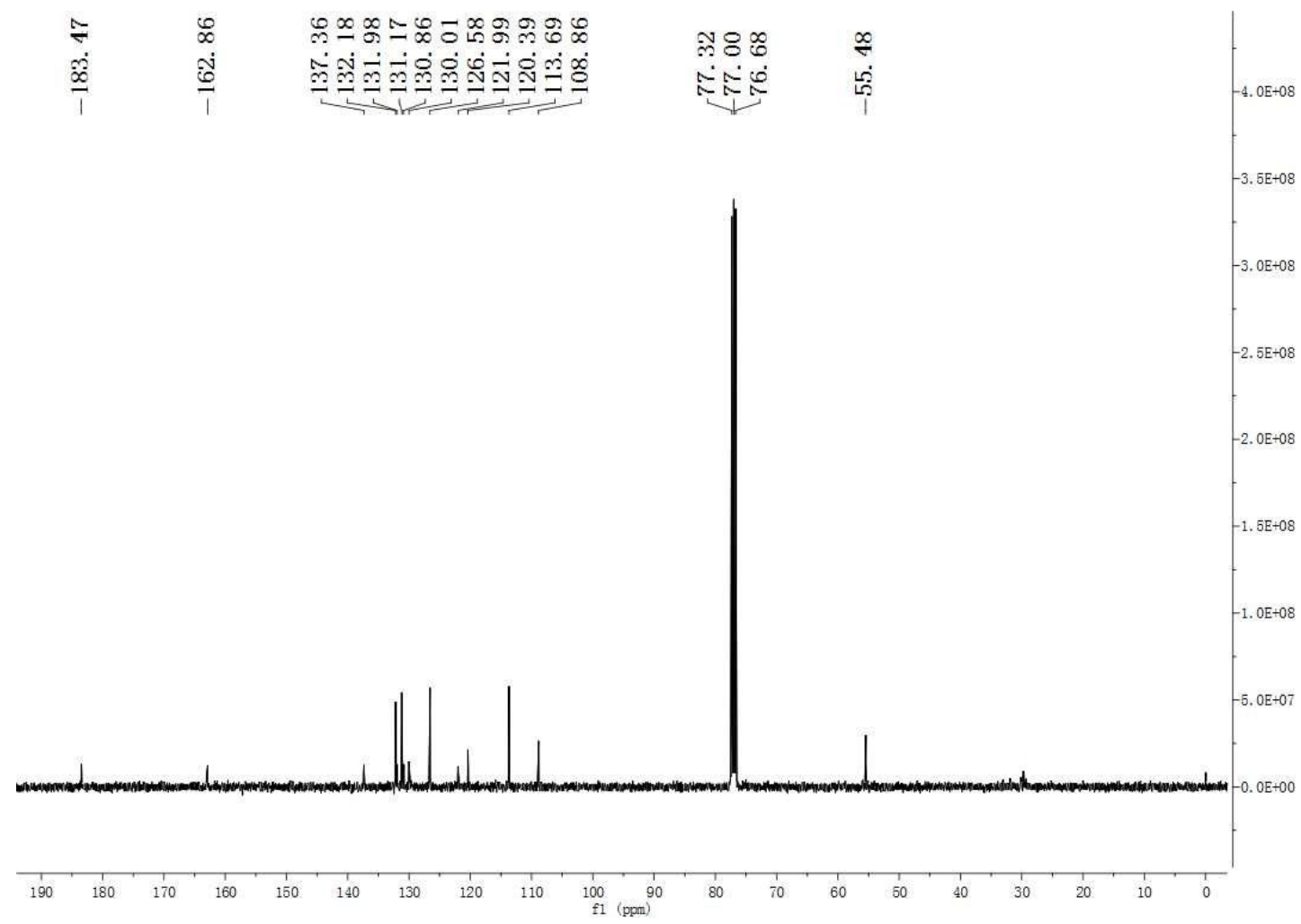

Figure S44. $100 \mathrm{MHz}{ }^{13} \mathrm{C}\left\{{ }^{1} \mathrm{H}\right\}$ NMR spectrum of 3v in $\mathrm{CDCl}_{3}$. 


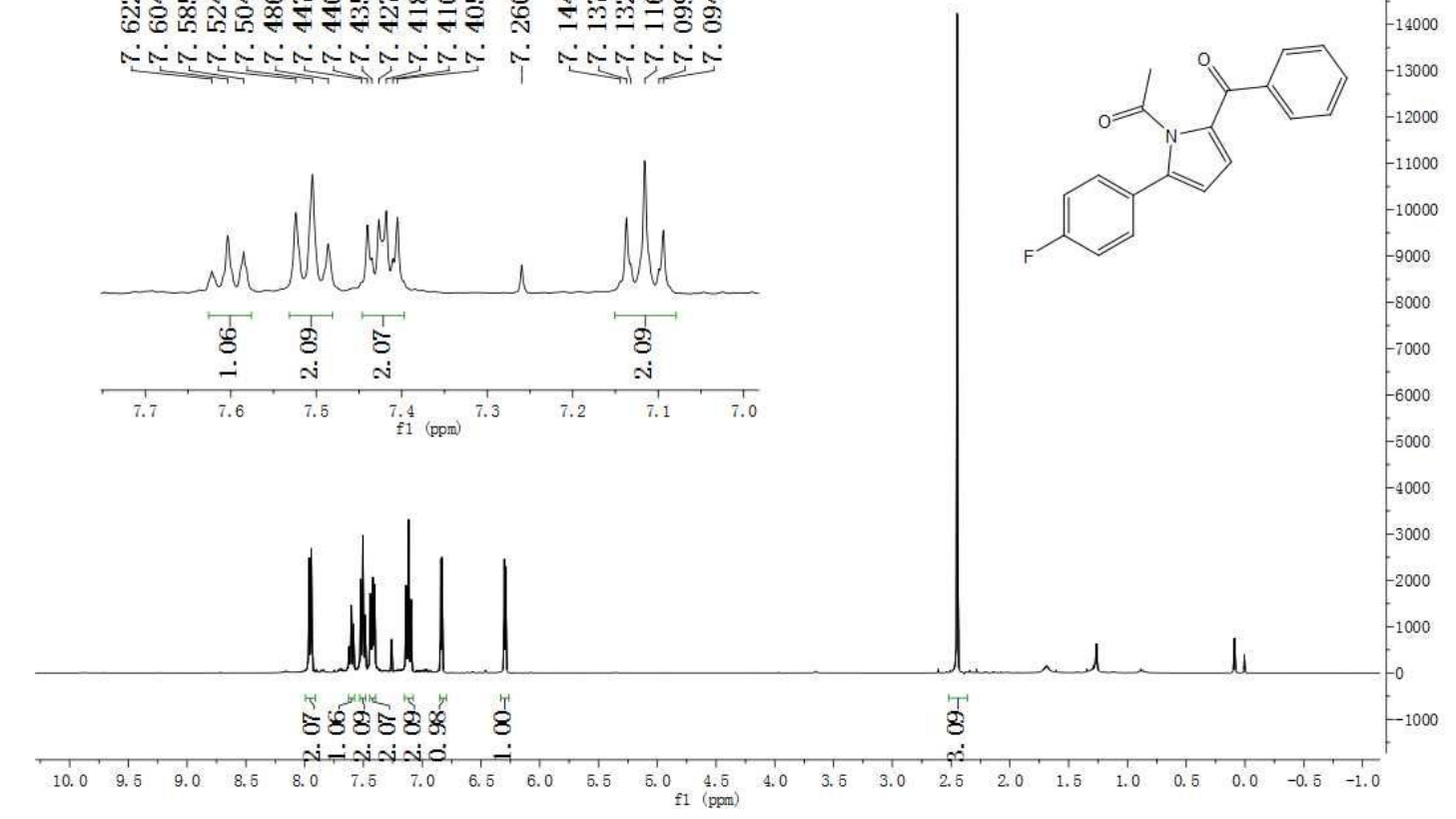

Figure $\mathbf{S 4 5 .} 400 \mathrm{MHz}{ }^{1} \mathrm{H}$ NMR spectrum of $\mathbf{3 w}$ in $\mathrm{CDCl}_{3}$

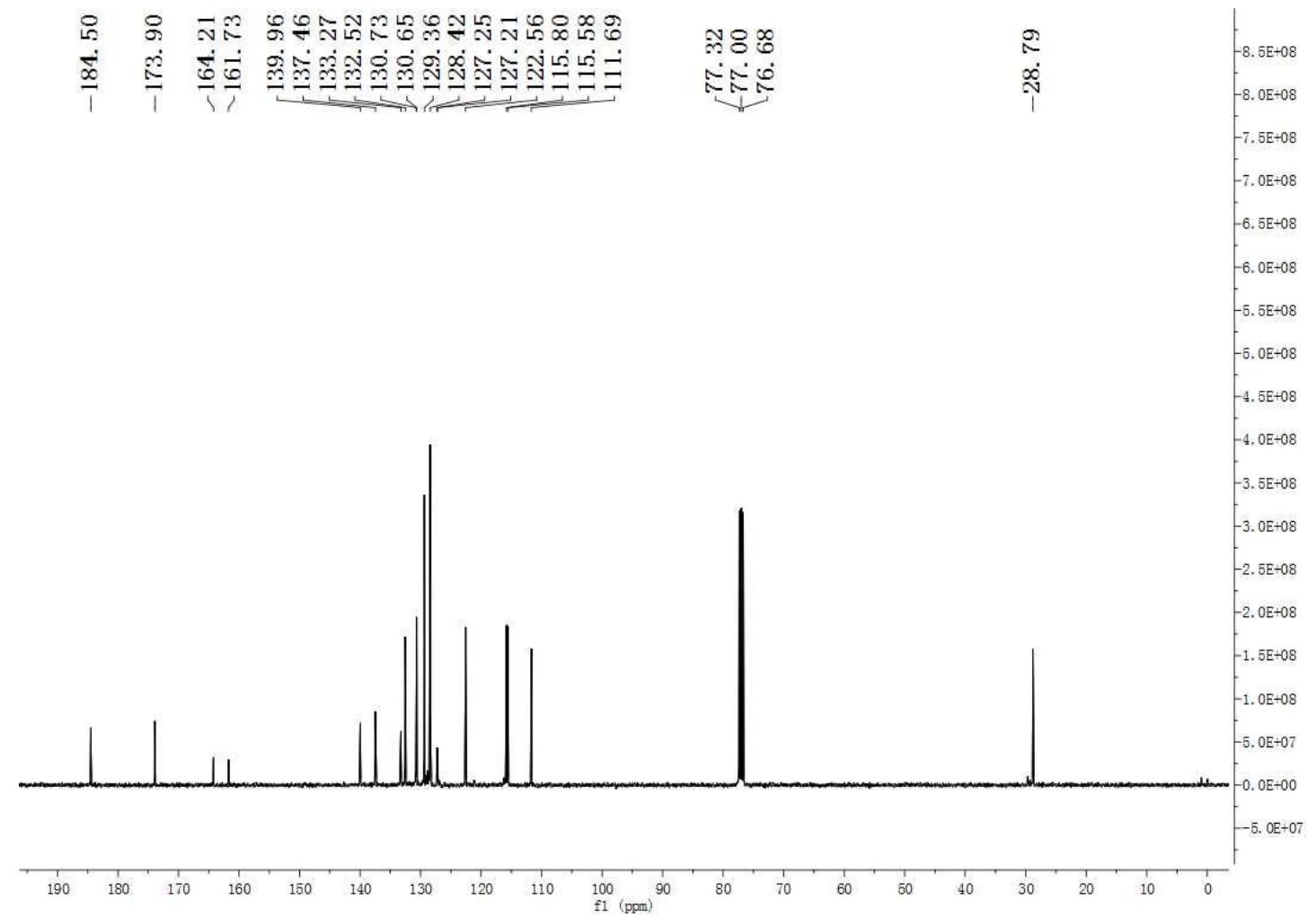

Figure S46. $100 \mathrm{MHz}{ }^{13} \mathrm{C}\left\{{ }^{1} \mathrm{H}\right\}$ NMR spectrum of 3w in $\mathrm{CDCl}_{3}$. 


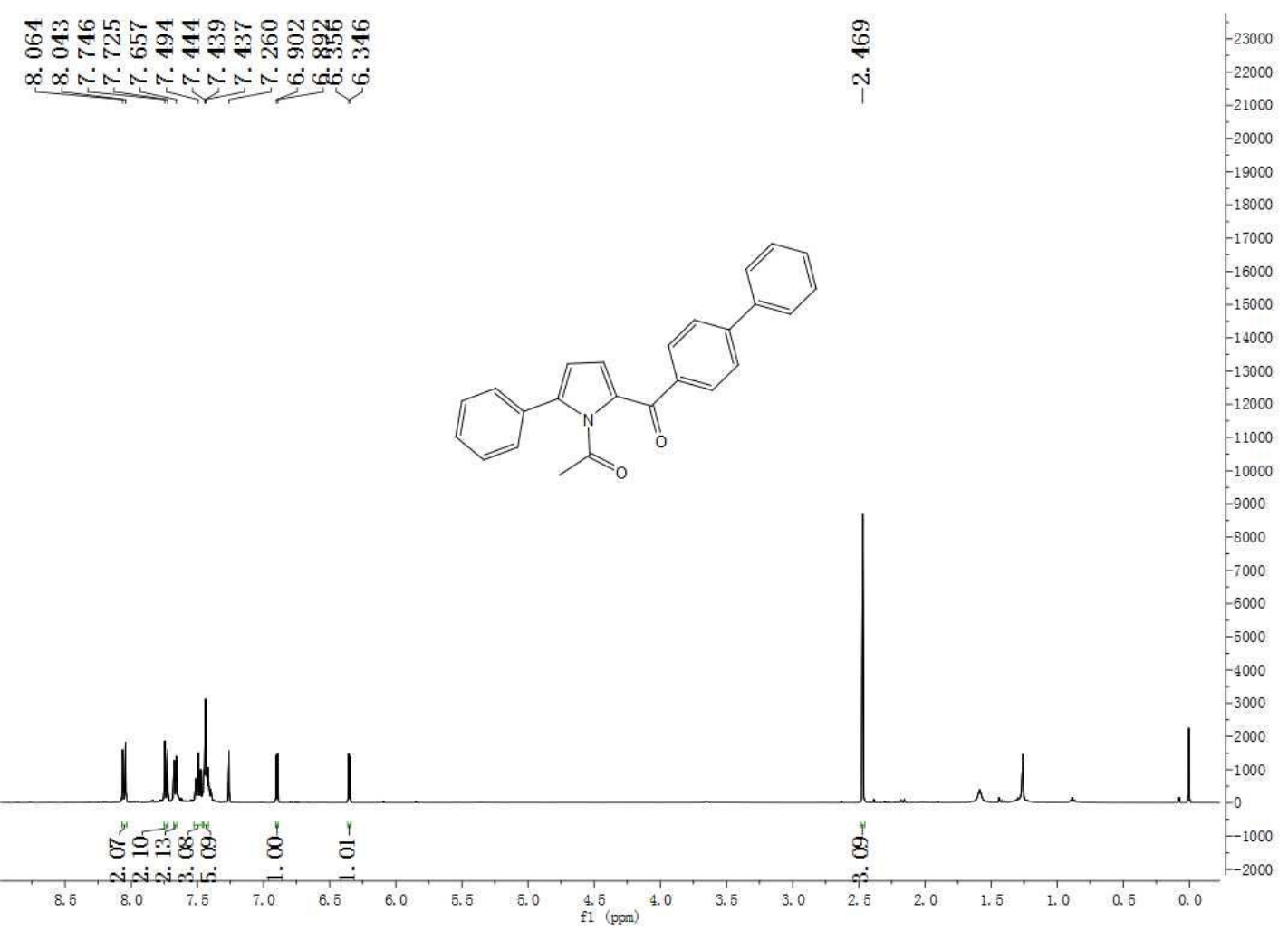

Figure S47. $400 \mathrm{MHz}{ }^{1} \mathrm{H}$ NMR spectrum of $\mathbf{3 x}$ in $\mathrm{CDCl}_{3}$

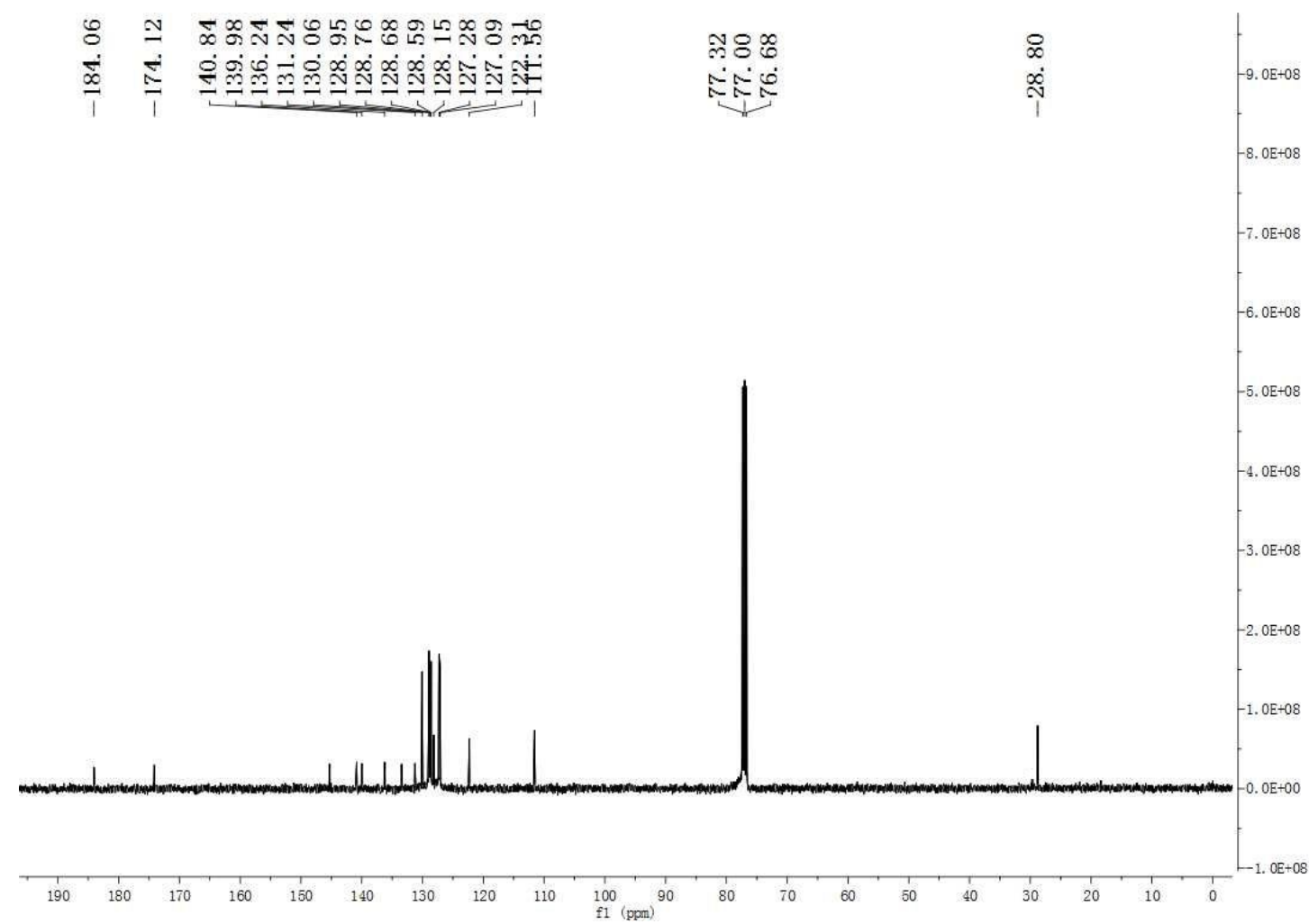

Figure S48. $100 \mathrm{MHz}{ }^{13} \mathrm{C}\left\{{ }^{1} \mathrm{H}\right\}$ NMR spectrum of $\mathbf{3 x}$ in $\mathrm{CDCl}_{3}$. 


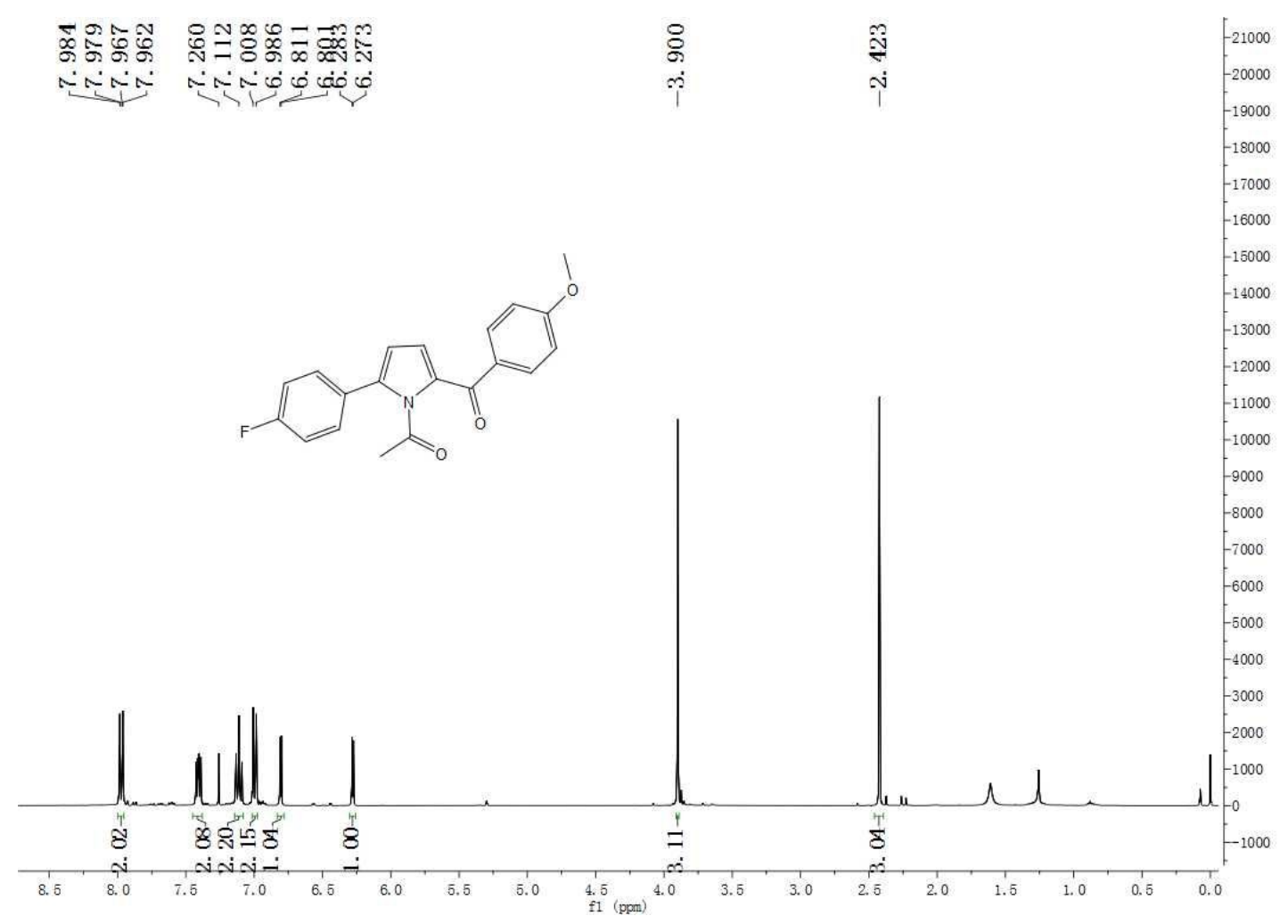

Figure S49. $400 \mathrm{MHz}{ }^{1} \mathrm{H}$ NMR spectrum of $\mathbf{3 y}$ in $\mathrm{CDCl}_{3}$

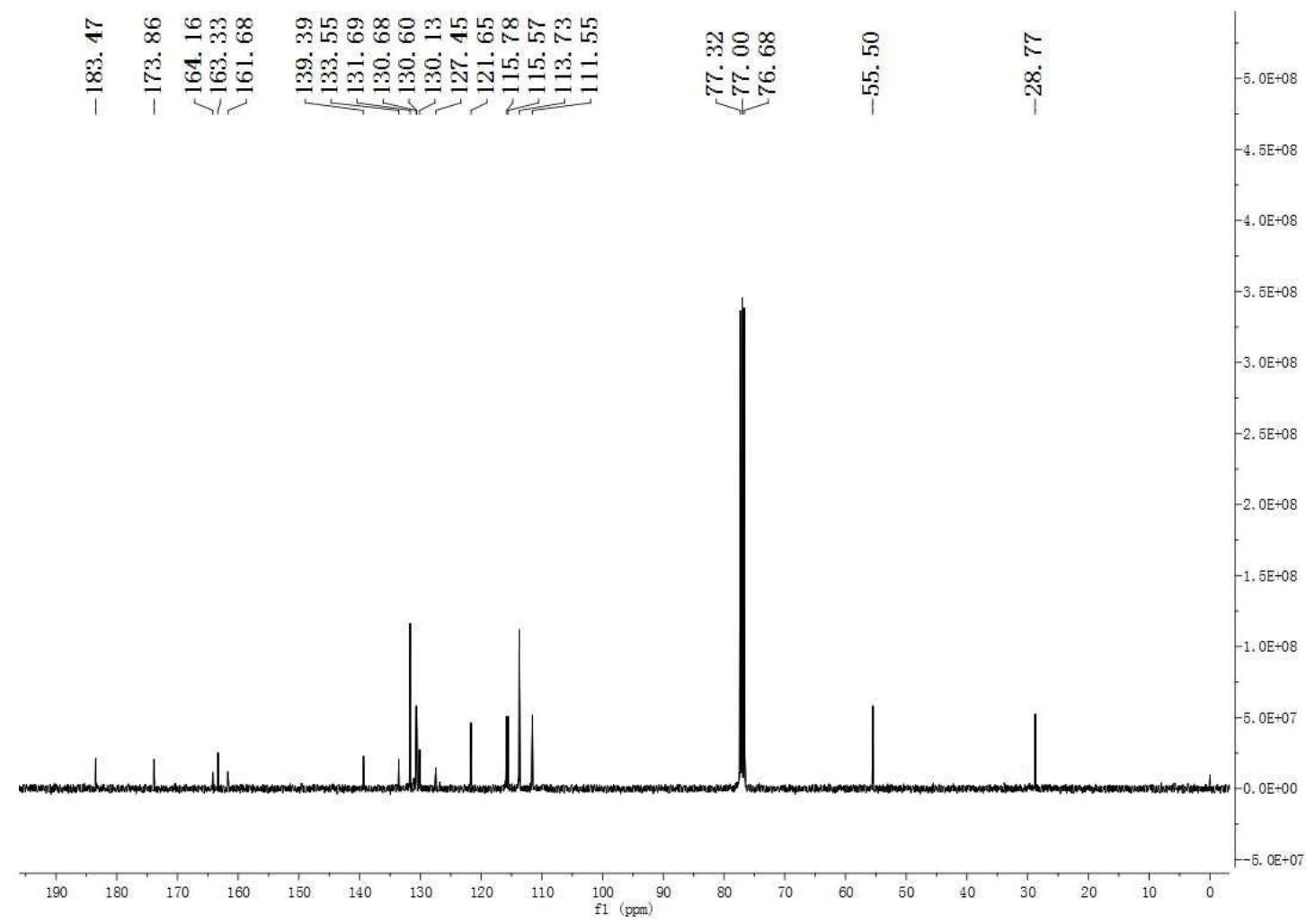

Figure S50. $100 \mathrm{MHz}{ }^{13} \mathrm{C}\left\{{ }^{1} \mathrm{H}\right\}$ NMR spectrum of $\mathbf{3 y}$ in $\mathrm{CDCl}_{3}$. 


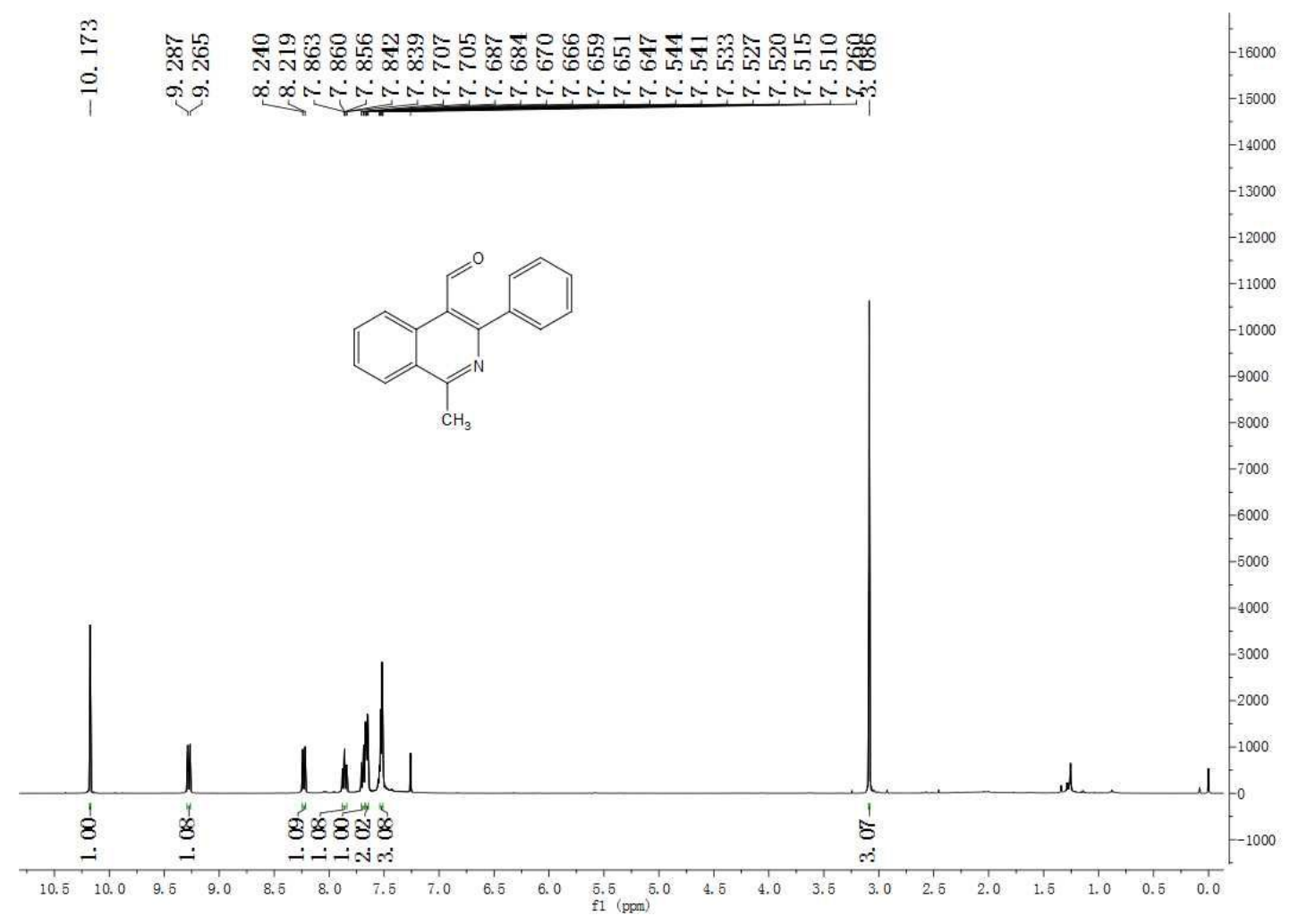

Figure S51. $400 \mathrm{MHz}{ }^{1} \mathrm{H}$ NMR spectrum of $4 \mathbf{a}$ in $\mathrm{CDCl}_{3}$

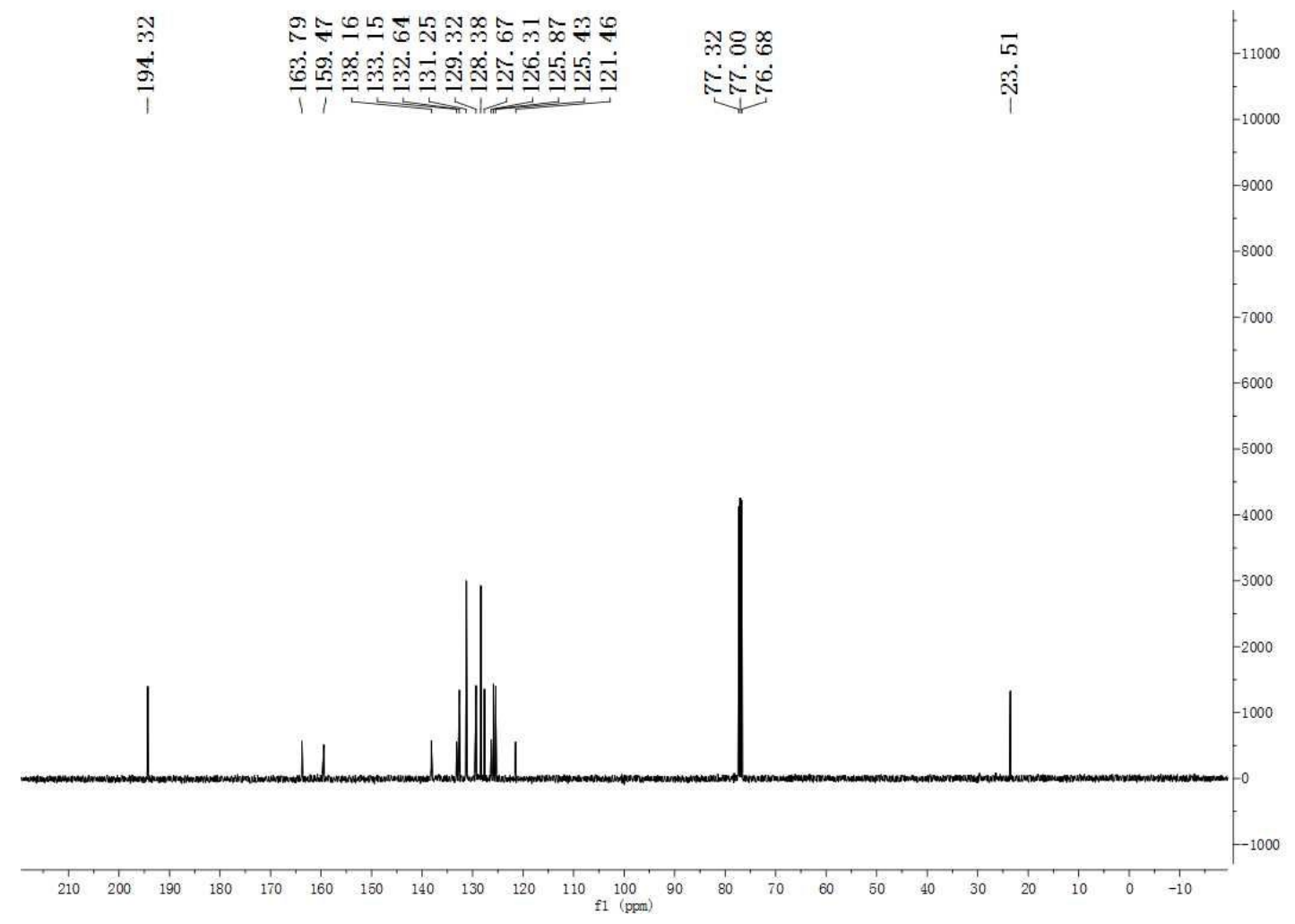

Figure S52. $100 \mathrm{MHz}{ }^{13} \mathrm{C}\left\{{ }^{1} \mathrm{H}\right\} \mathrm{NMR}$ spectrum of $4 \mathbf{a}$ in $\mathrm{CDCl}_{3}$. 

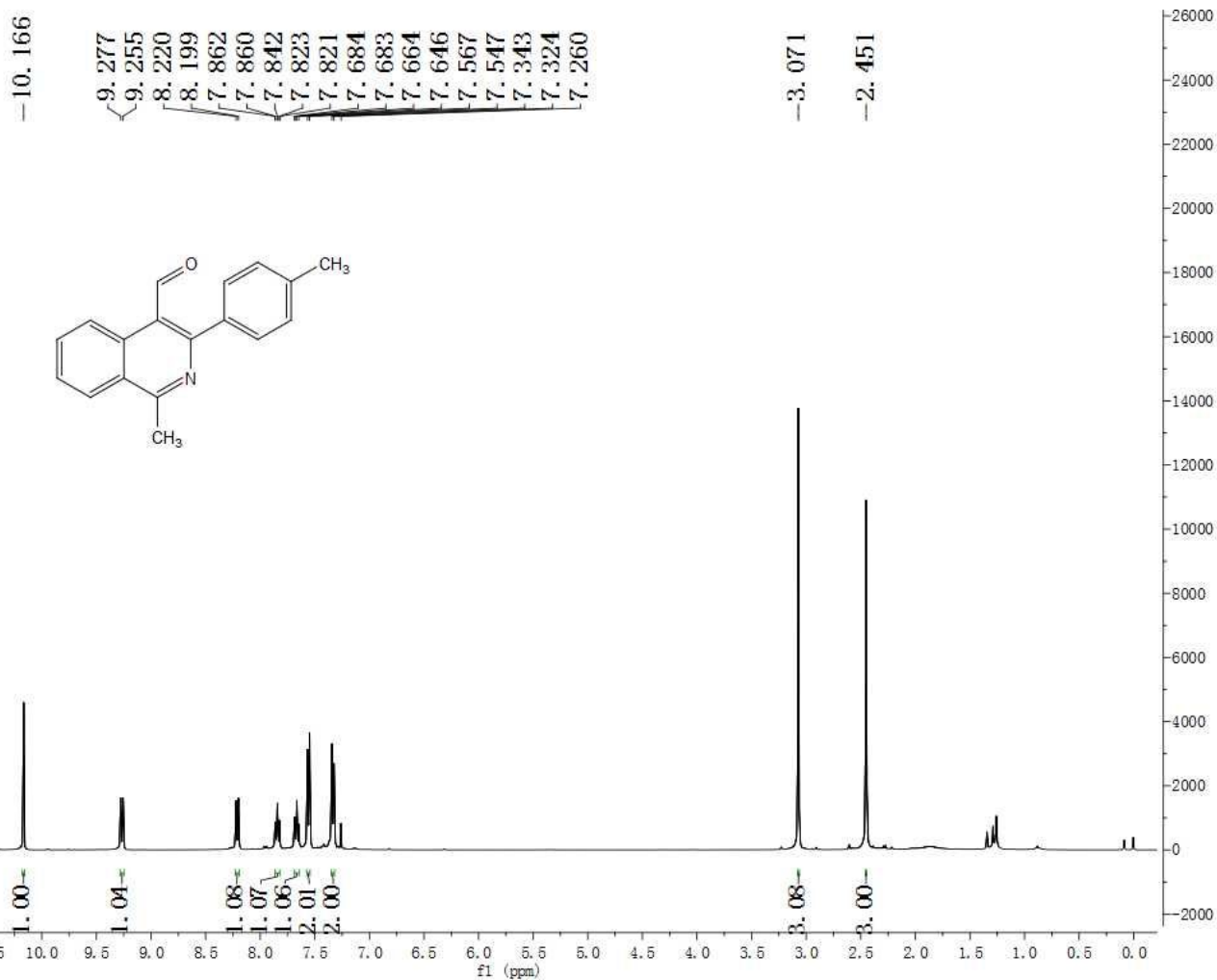

Figure S53. $400 \mathrm{MHz}{ }^{1} \mathrm{H}$ NMR spectrum of $\mathbf{4 b}$ in $\mathrm{CDCl}_{3}$

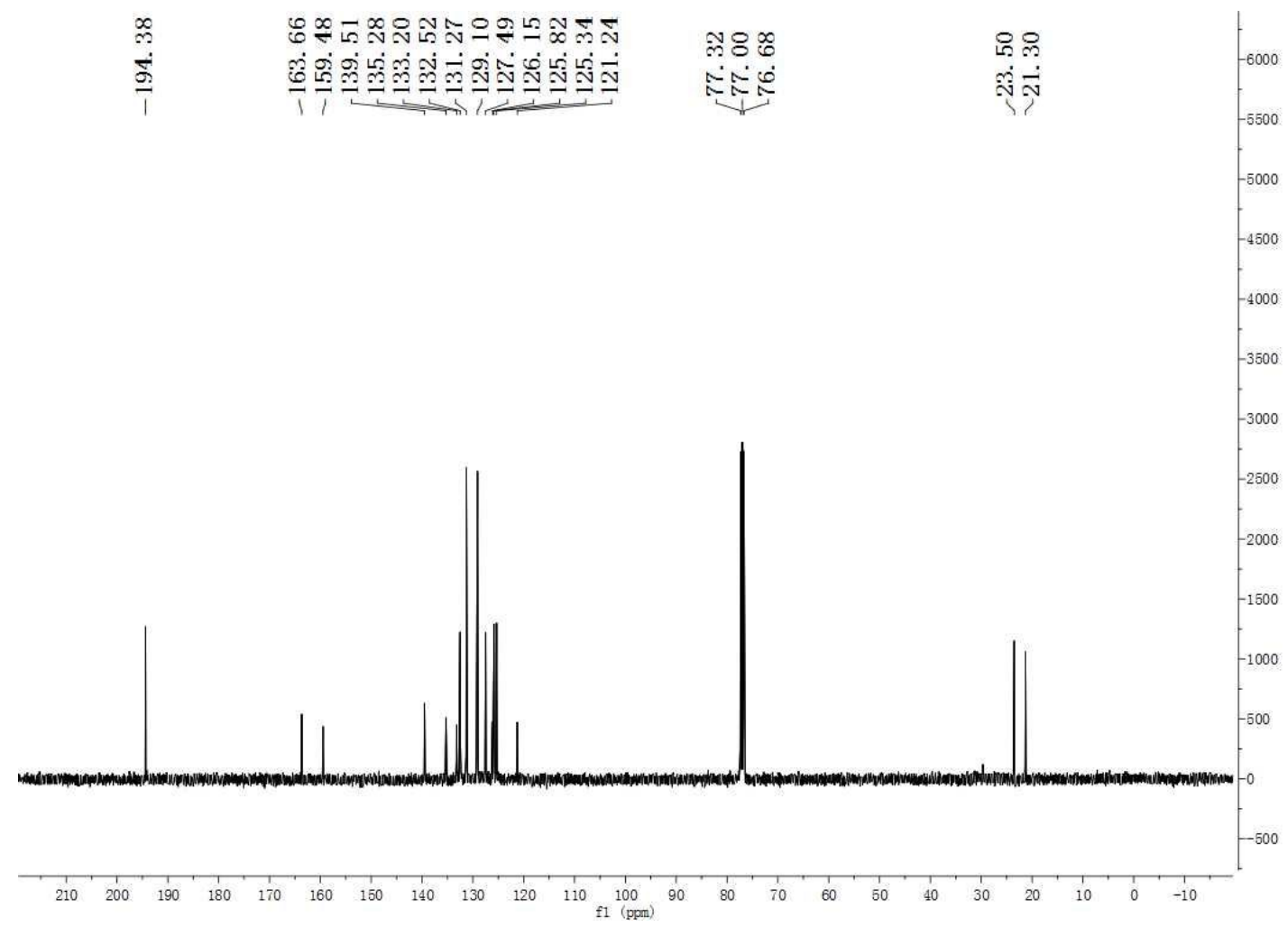

Figure S54. $100 \mathrm{MHz}{ }^{13} \mathrm{C}\left\{{ }^{1} \mathrm{H}\right\}$ NMR spectrum of $\mathbf{4 b}$ in $\mathrm{CDCl}_{3}$. 


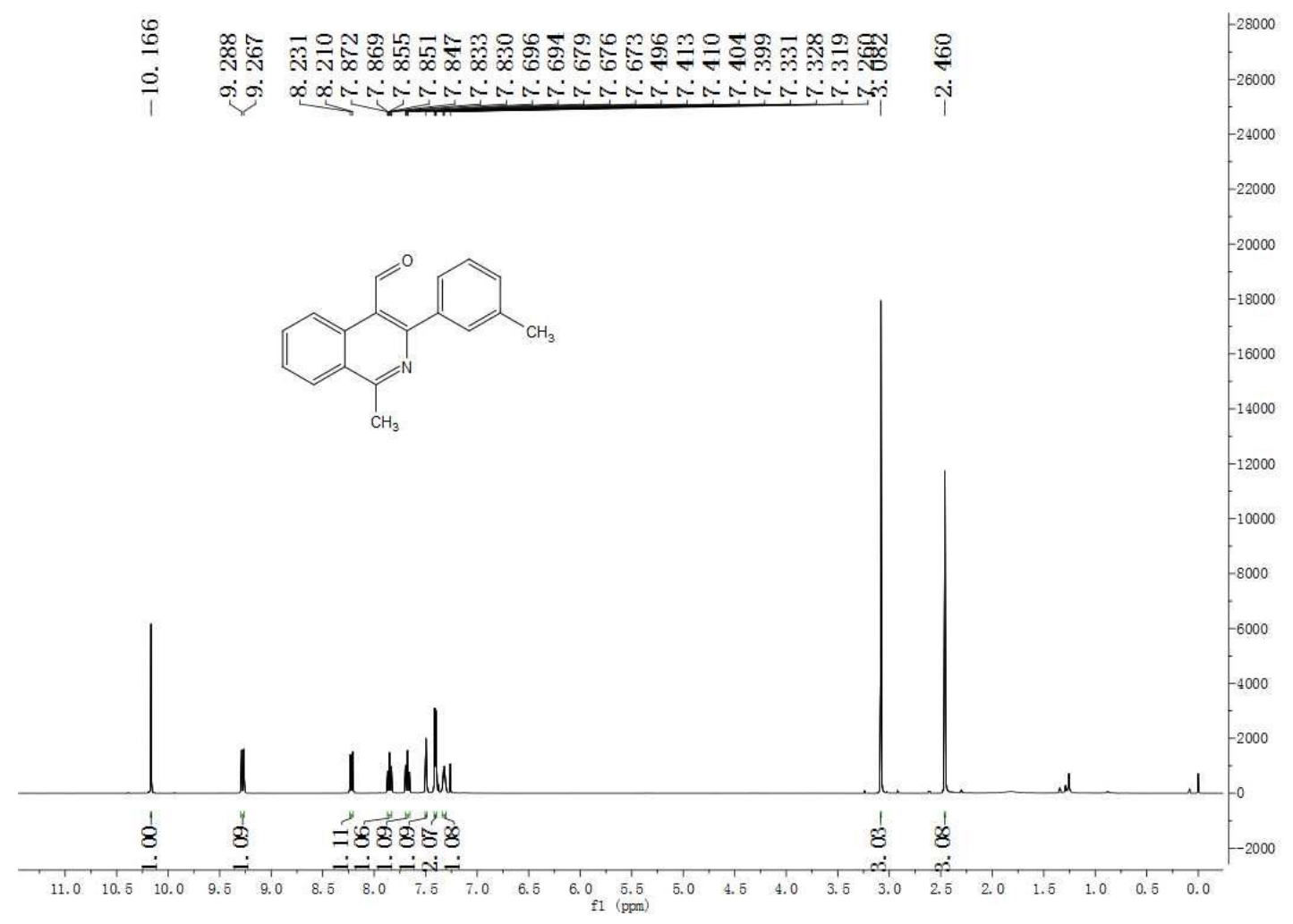

Figure S55. $400 \mathrm{MHz}{ }^{1} \mathrm{H}$ NMR spectrum of $\mathbf{4 c}$ in $\mathrm{CDCl}_{3}$

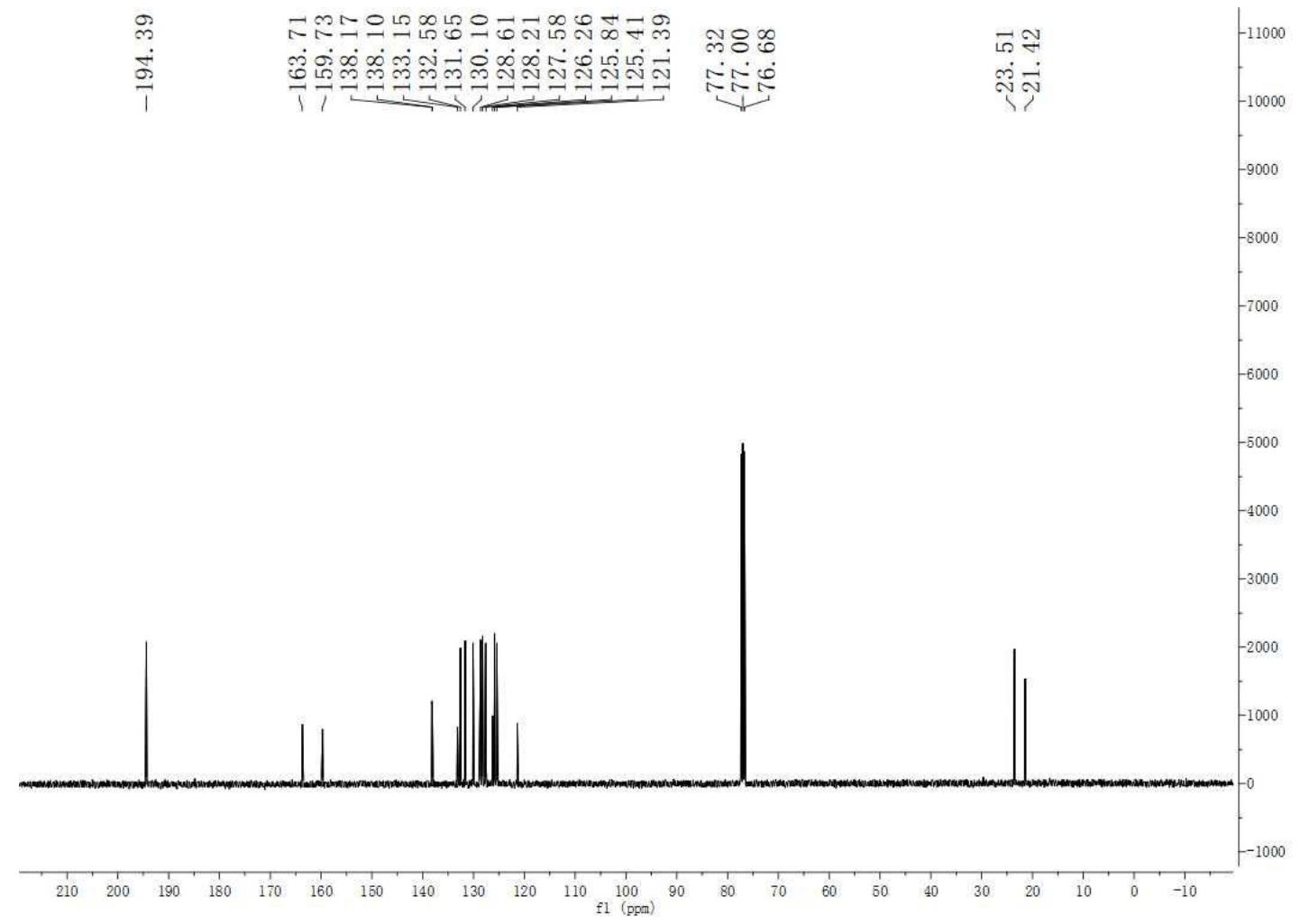

Figure S56. $100 \mathrm{MHz}{ }^{13} \mathrm{C}\left\{{ }^{1} \mathrm{H}\right\}$ NMR spectrum of $4 \mathbf{c}$ in $\mathrm{CDCl}_{3}$. 


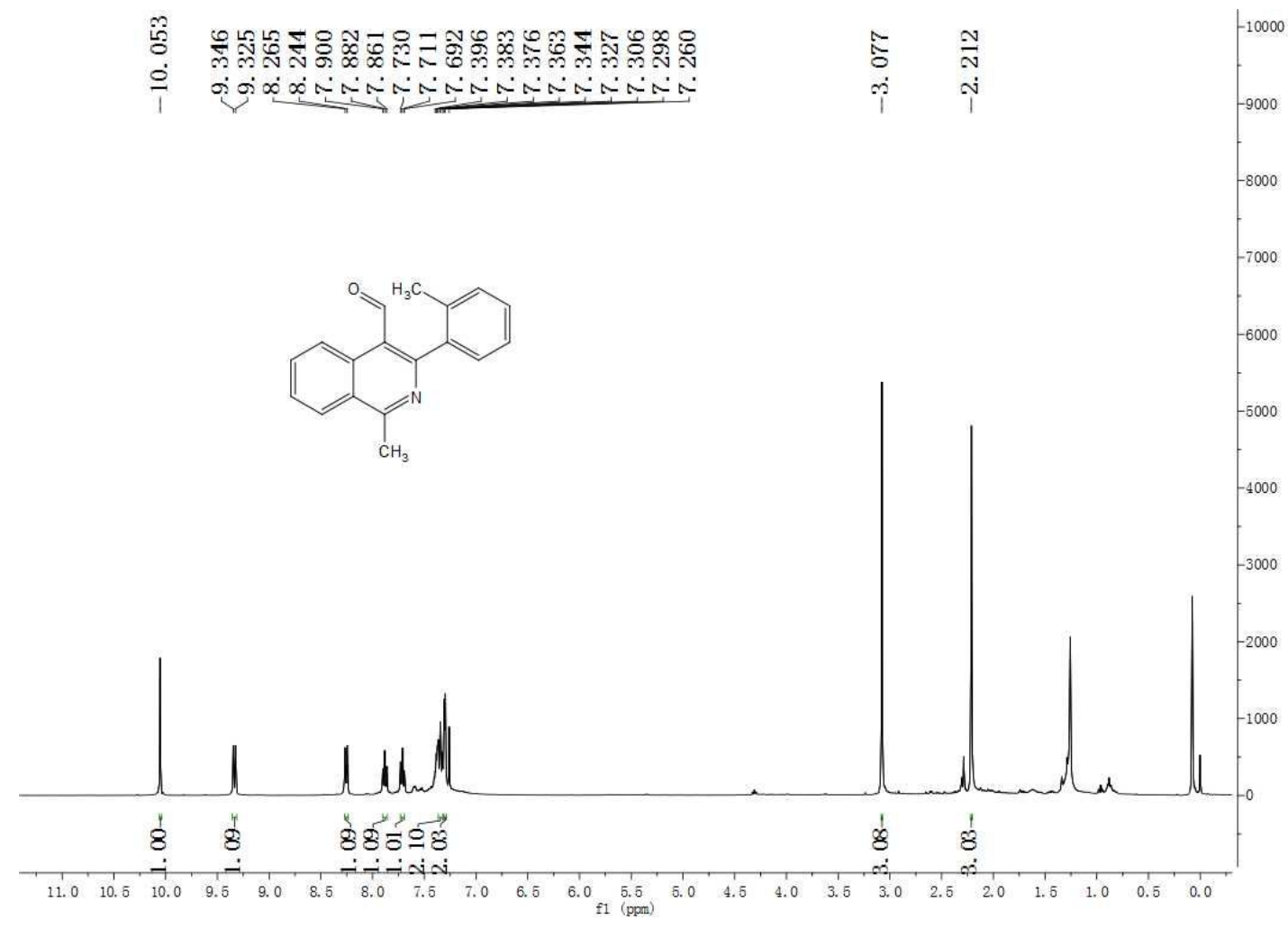

Figure S57. $400 \mathrm{MHz}{ }^{1} \mathrm{H}$ NMR spectrum of $\mathbf{4 d}$ in $\mathrm{CDCl}_{3}$

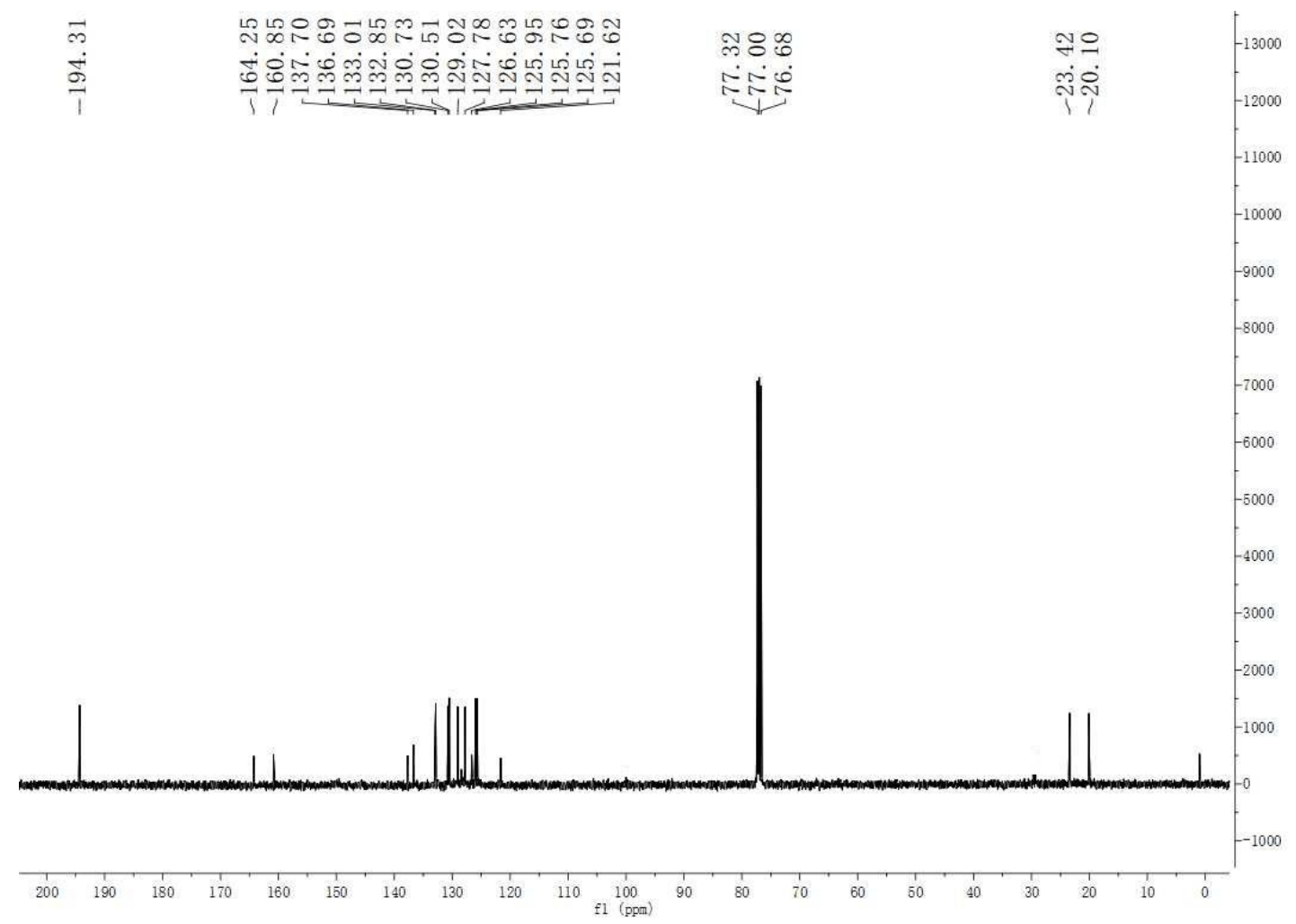

Figure S58. $100 \mathrm{MHz}{ }^{13} \mathrm{C}\left\{{ }^{1} \mathrm{H}\right\}$ NMR spectrum of $\mathbf{4 d}$ in $\mathrm{CDCl}_{3}$. 


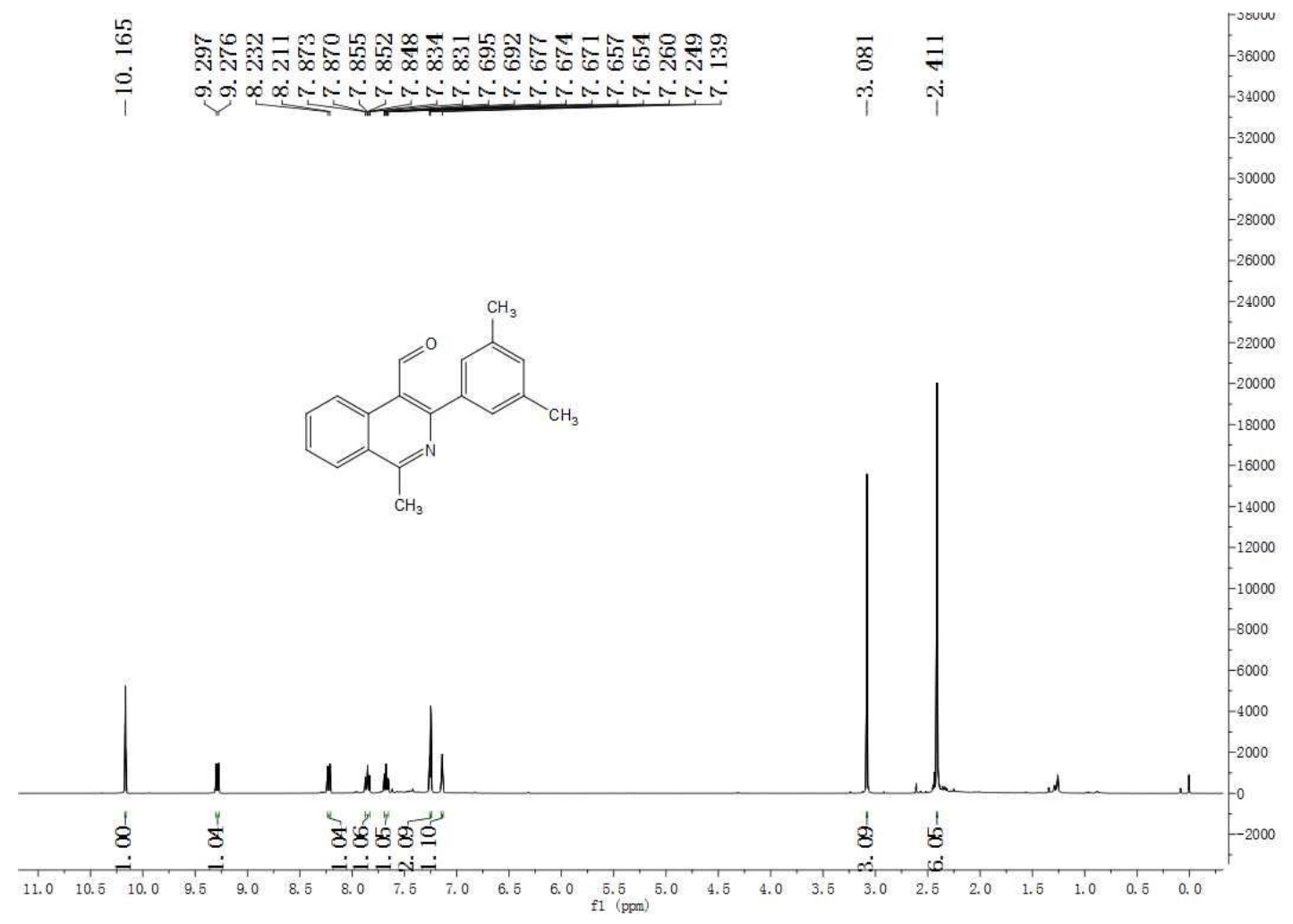

Figure S59. $400 \mathrm{MHz}{ }^{1} \mathrm{H}$ NMR spectrum of $4 \mathbf{e}$ in $\mathrm{CDCl}_{3}$

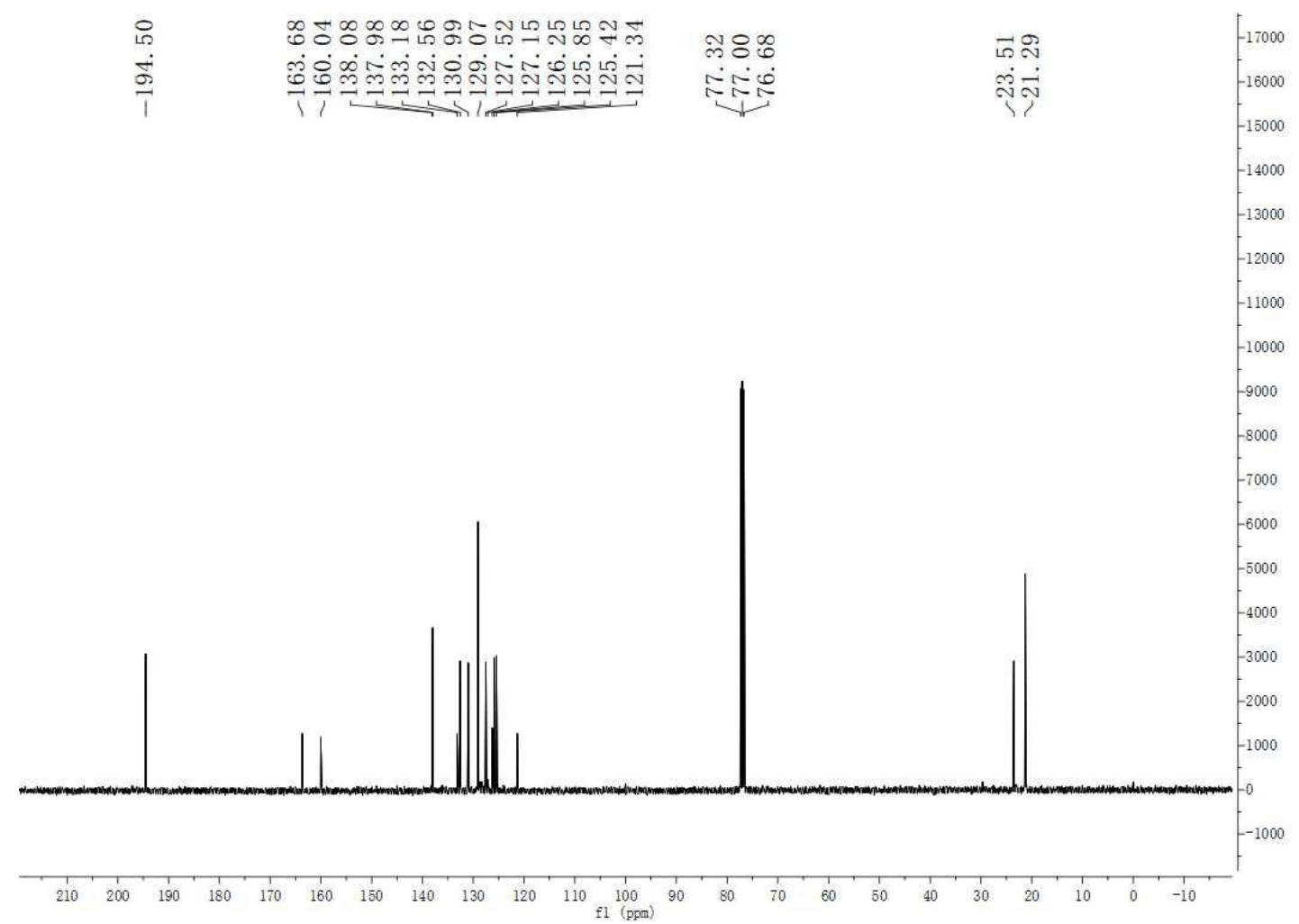

Figure S60. $100 \mathrm{MHz}{ }^{13} \mathrm{C}\left\{{ }^{1} \mathrm{H}\right\}$ NMR spectrum of $4 \mathbf{e}$ in $\mathrm{CDCl}_{3}$. 


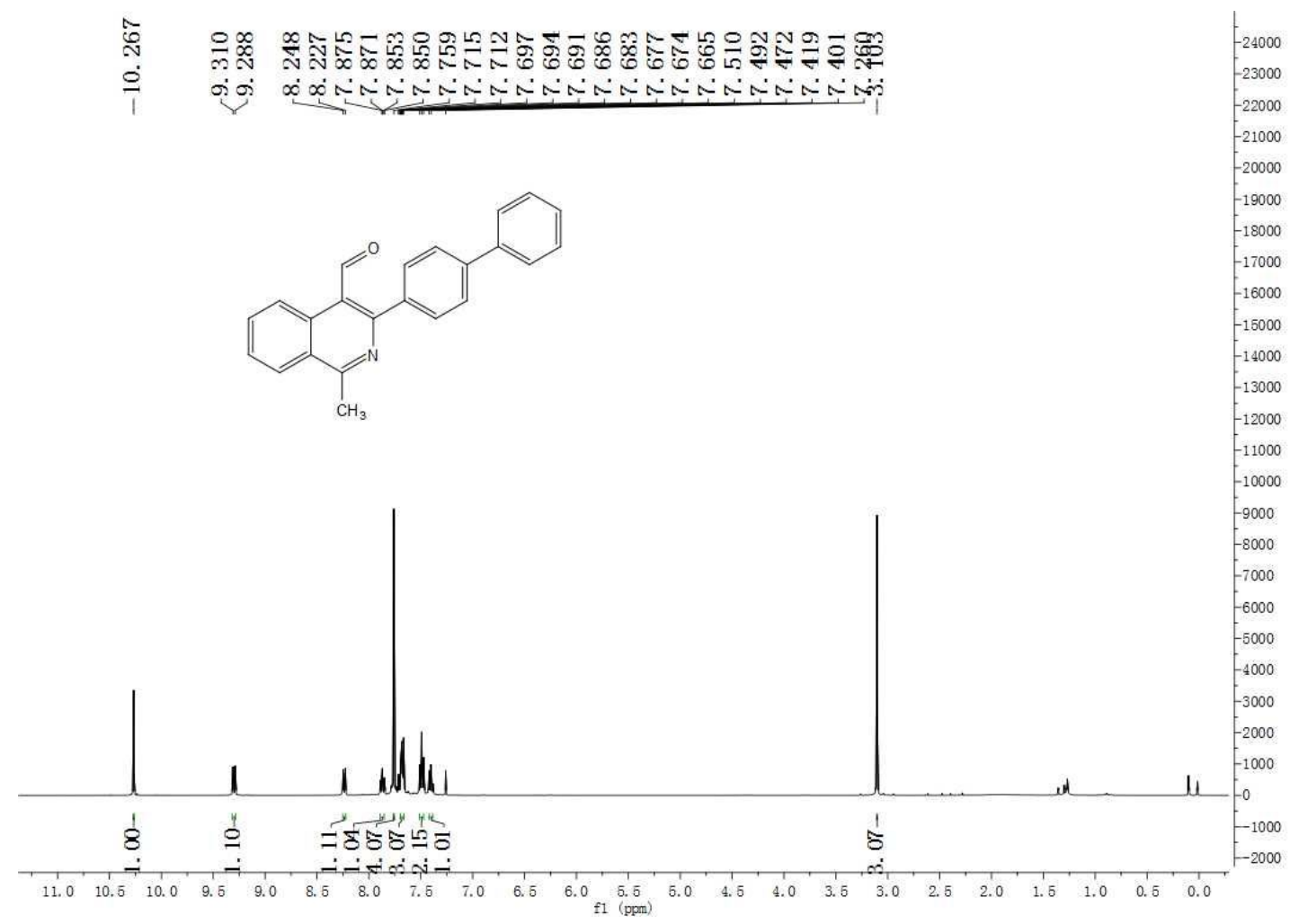

Figure S61. $400 \mathrm{MHz}{ }^{1} \mathrm{H}$ NMR spectrum of $\mathbf{4 f}$ in $\mathrm{CDCl}_{3}$

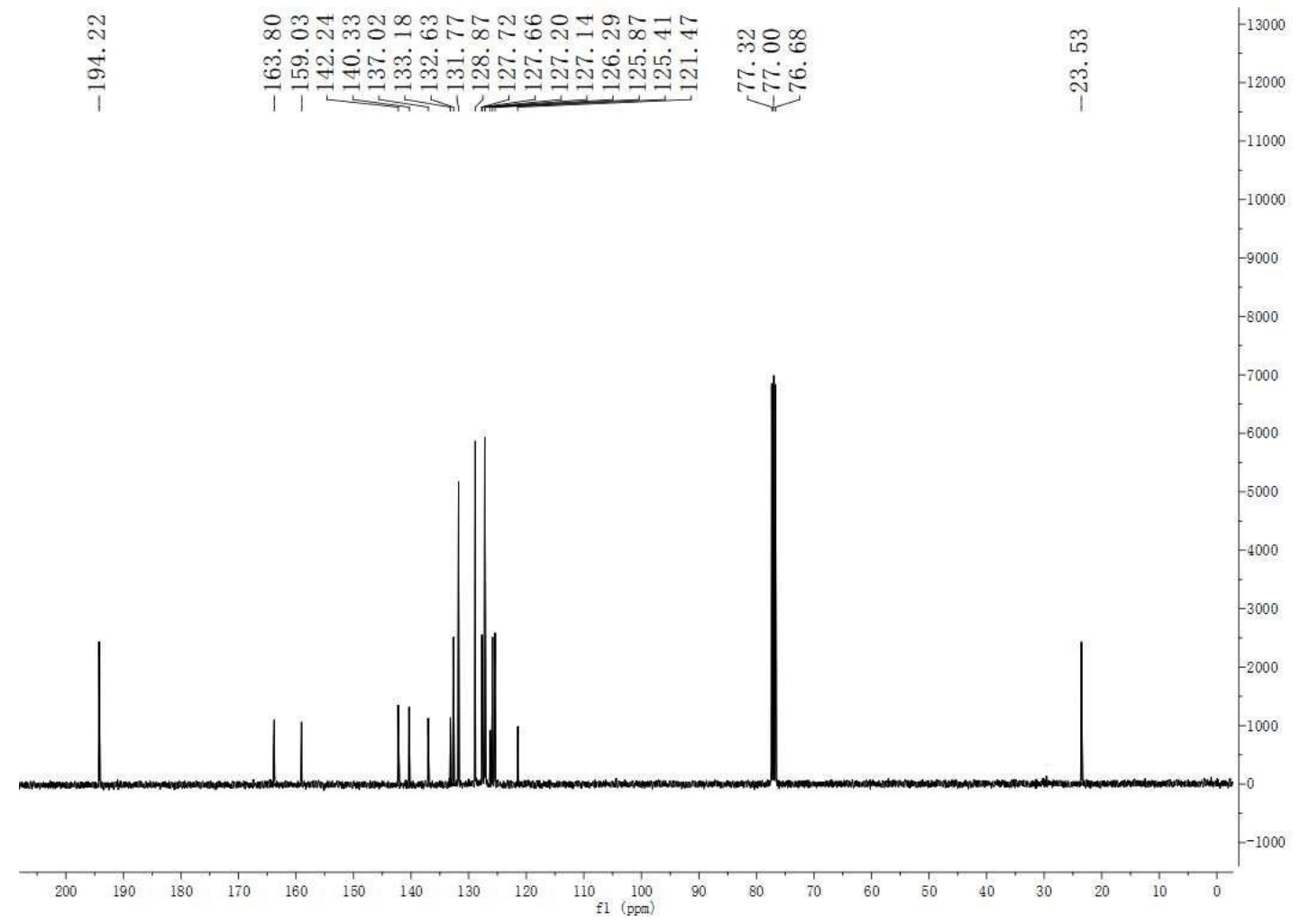

Figure S62. $100 \mathrm{MHz}{ }^{13} \mathrm{C}\left\{{ }^{1} \mathrm{H}\right\}$ NMR spectrum of $\mathbf{4 f}$ in $\mathrm{CDCl}_{3}$. 


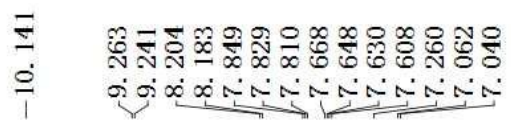

$\begin{array}{ll}\infty & \overline{0} \\ \infty & \overline{8} \\ \dot{\gamma} & \rho\end{array}$

$-12000$

gox-N-NiN-N
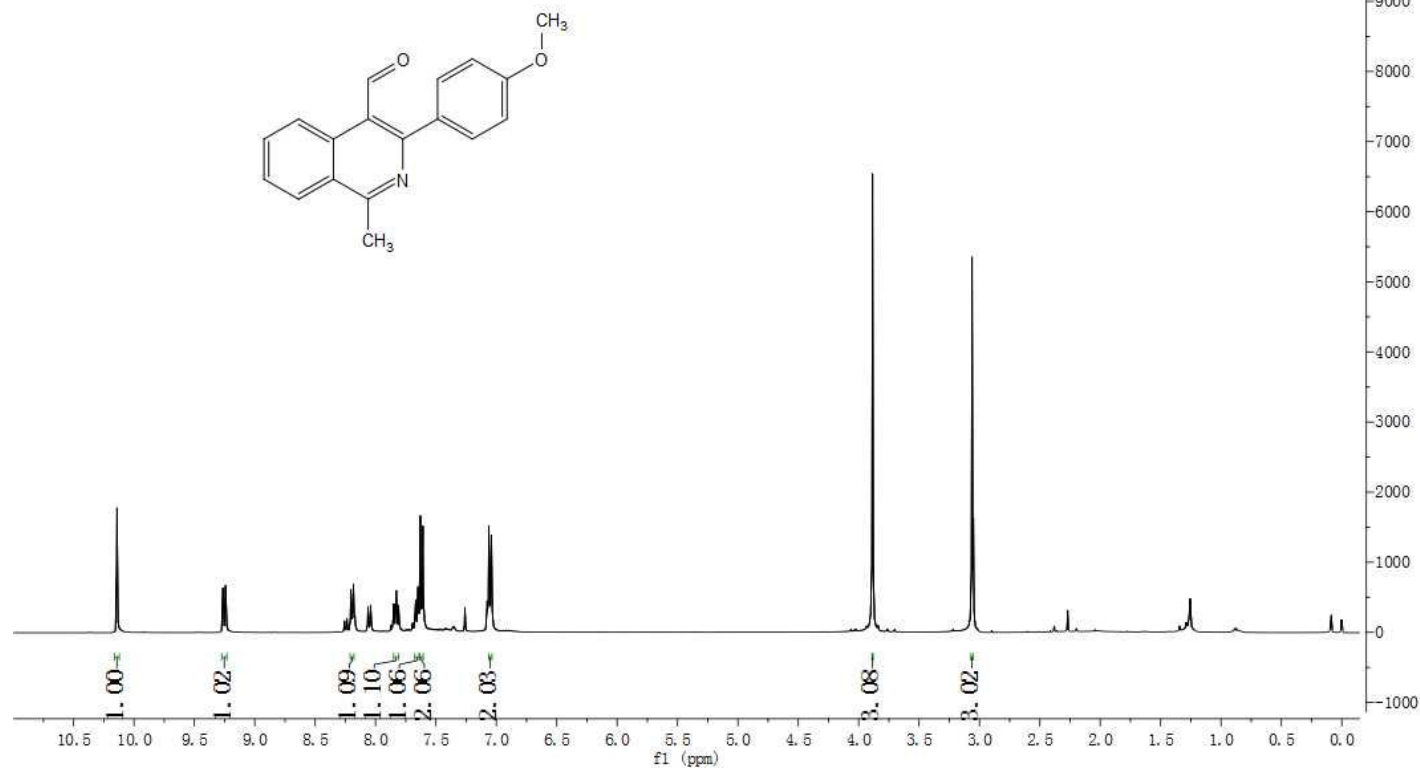

Figure S63. $400 \mathrm{MHz}{ }^{1} \mathrm{H}$ NMR spectrum of $\mathbf{4 g}$ in $\mathrm{CDCl}_{3}$

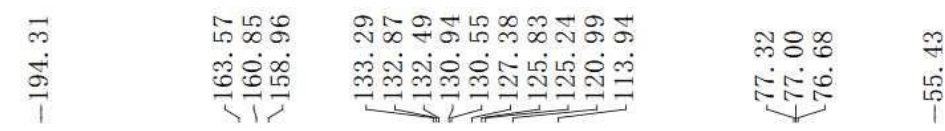

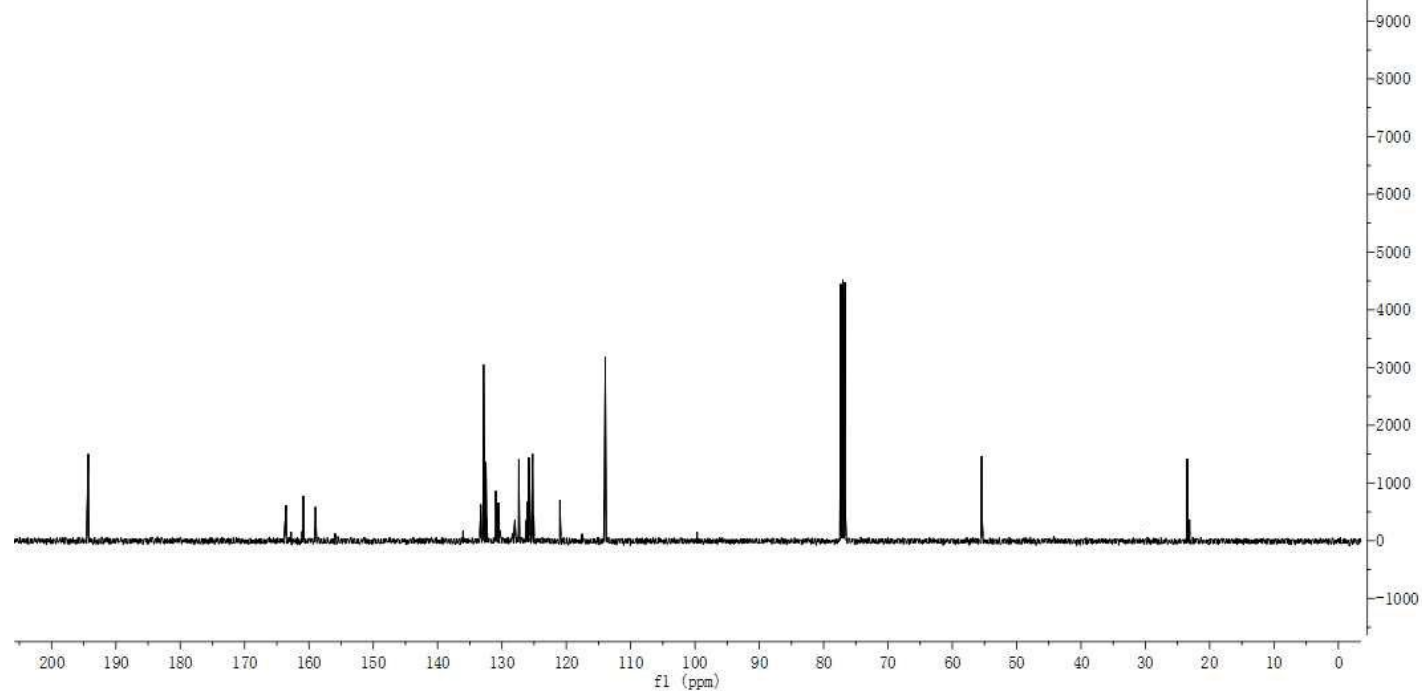

Figure S64. $100 \mathrm{MHz}{ }^{13} \mathrm{C}\left\{{ }^{1} \mathrm{H}\right\}$ NMR spectrum of $\mathbf{4 g}$ in $\mathrm{CDCl}_{3}$. 


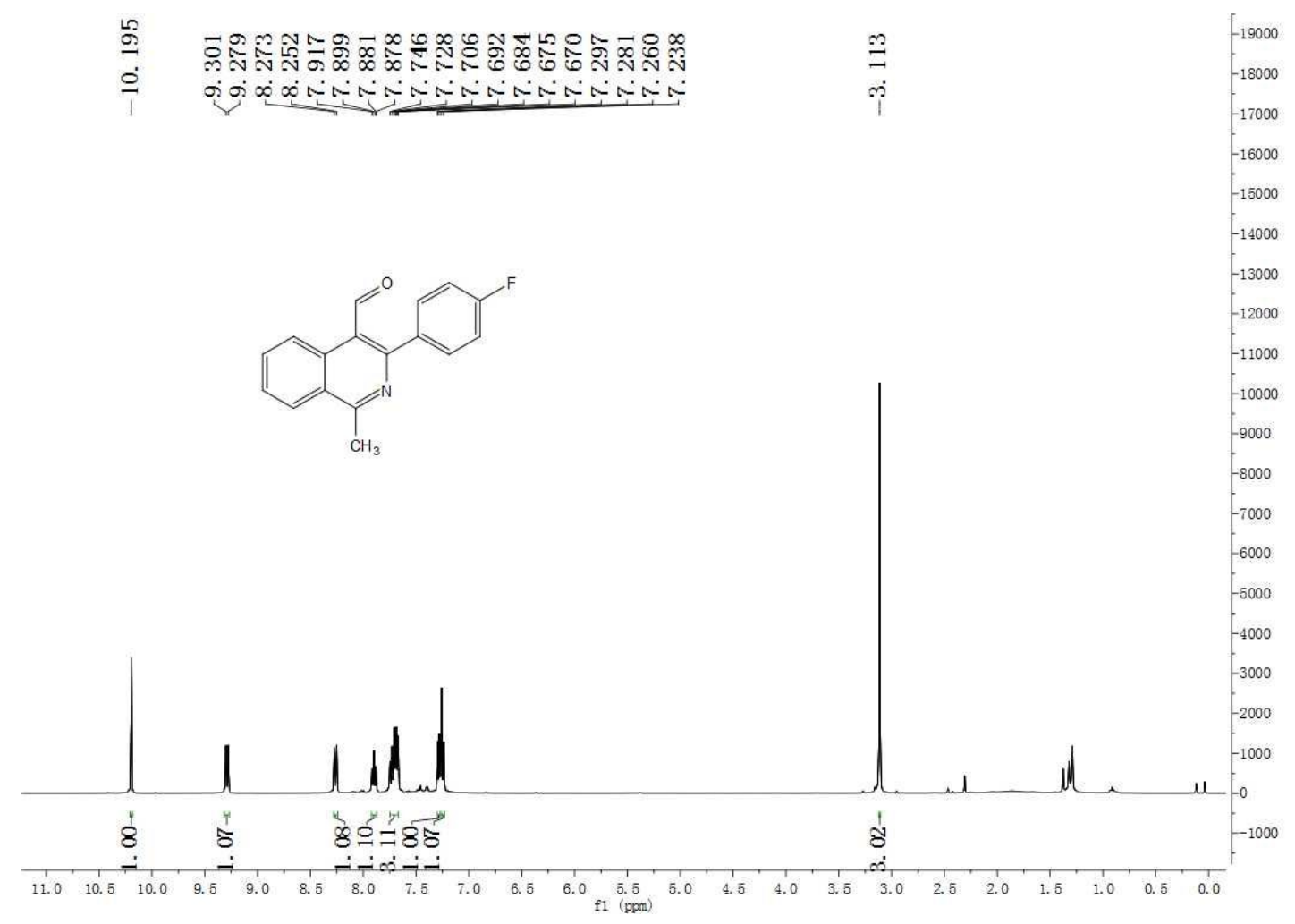

Figure S65. $400 \mathrm{MHz}{ }^{1} \mathrm{H} \mathrm{NMR}$ spectrum of $\mathbf{4 h}$ in $\mathrm{CDCl}_{3}$

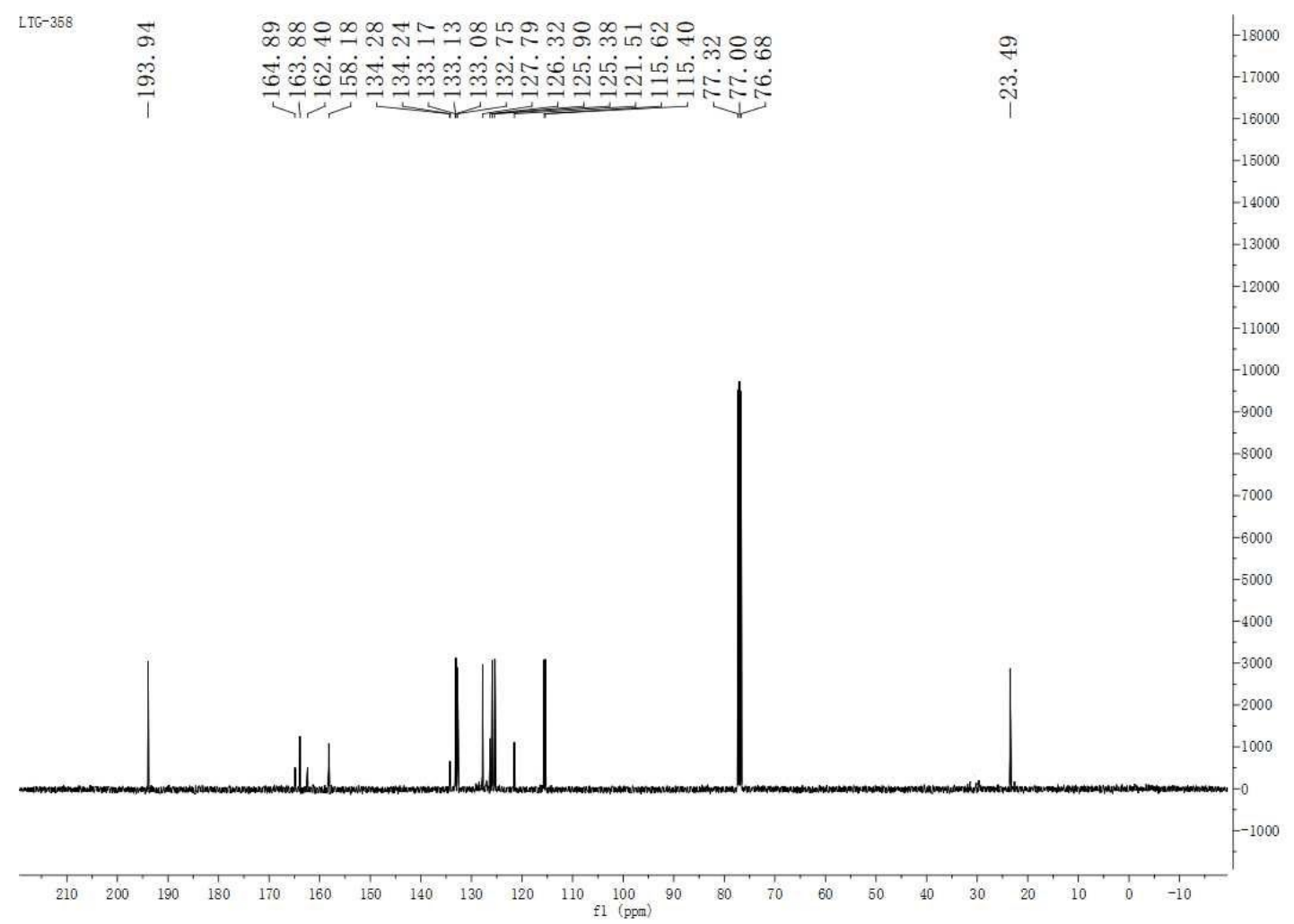

Figure S66. $100 \mathrm{MHz}{ }^{13} \mathrm{C}\left\{{ }^{1} \mathrm{H}\right\}$ NMR spectrum of $\mathbf{4 h}$ in $\mathrm{CDCl}_{3}$. 


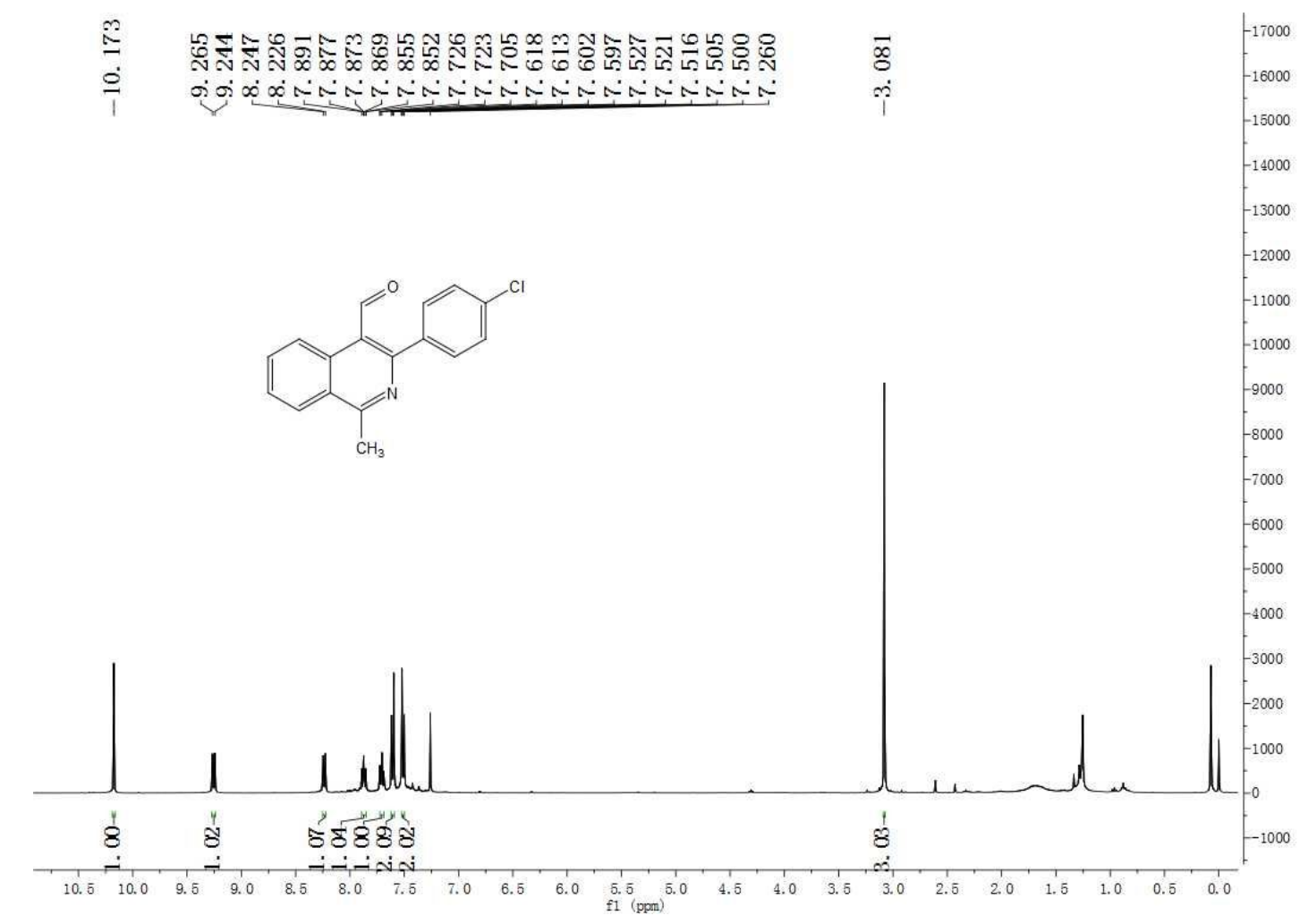

Figure S67. $400 \mathrm{MHz}^{1} \mathrm{H}$ NMR spectrum of $4 \mathbf{i}$ in $\mathrm{CDCl}_{3}$

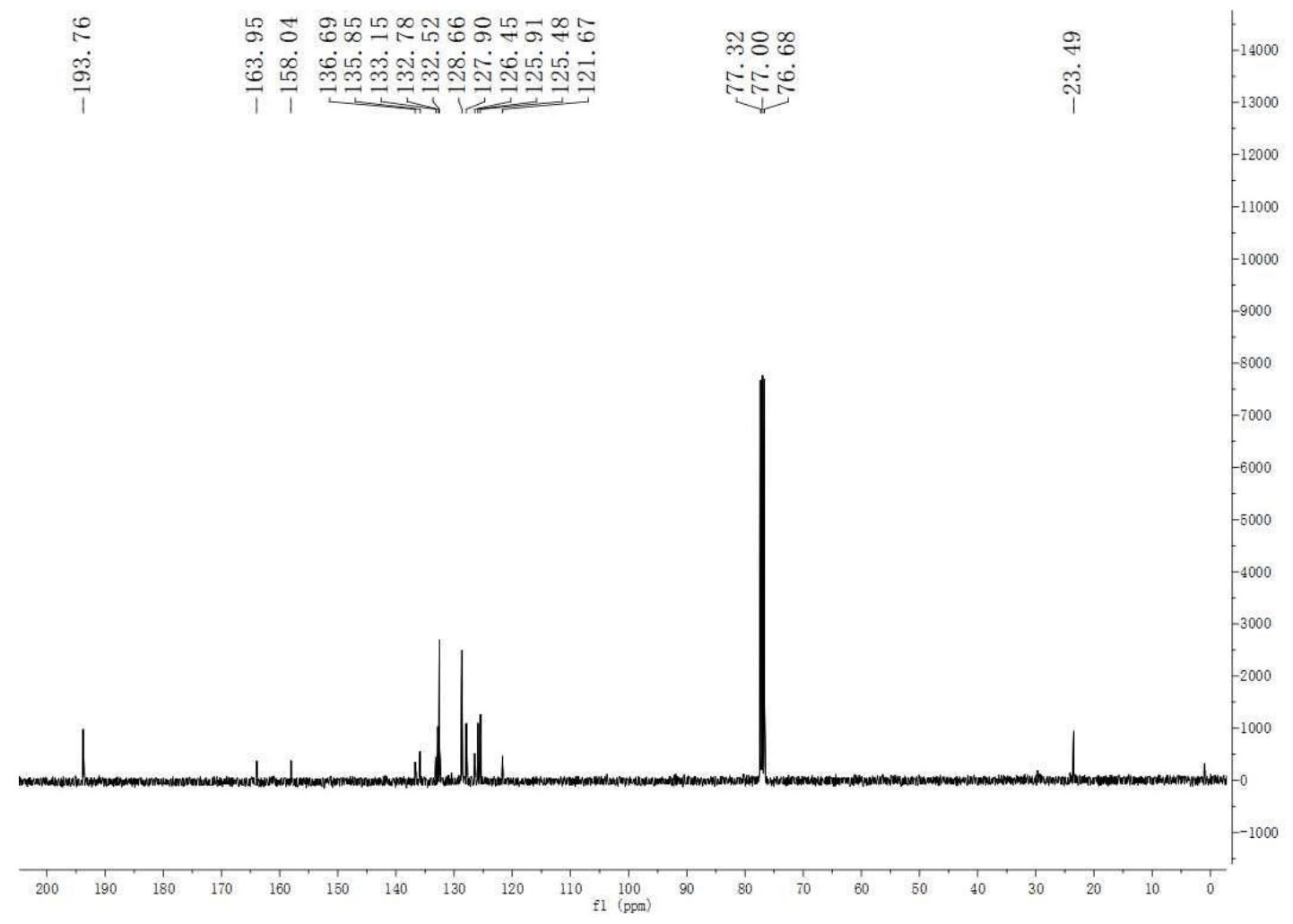

Figure S68. $100 \mathrm{MHz}{ }^{13} \mathrm{C}\left\{{ }^{1} \mathrm{H}\right\} \mathrm{NMR}$ spectrum of $\mathbf{4 i}$ in $\mathrm{CDCl}_{3}$. 


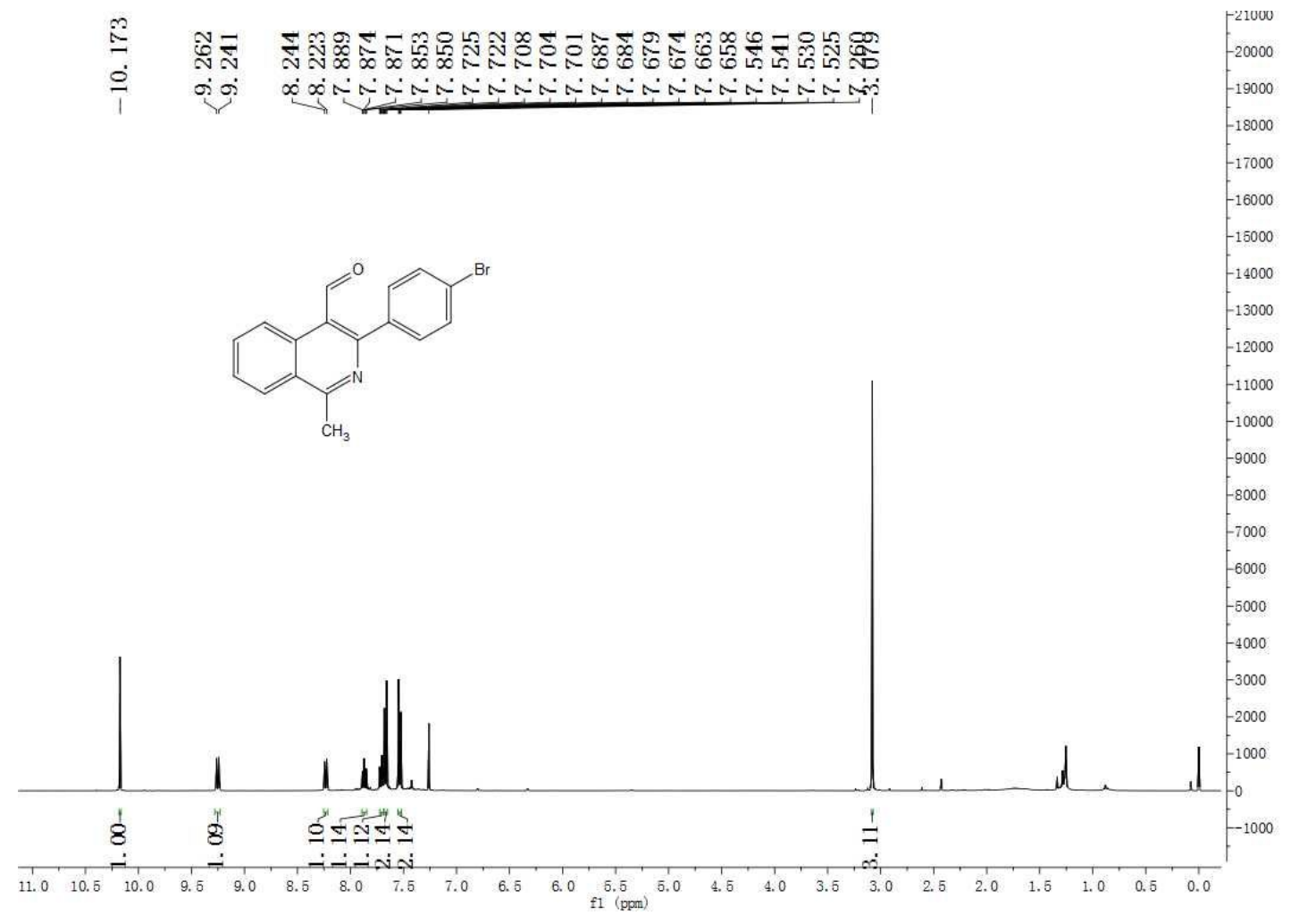

Figure S69. $400 \mathrm{MHz}{ }^{1} \mathrm{H}$ NMR spectrum of $\mathbf{4 j}$ in $\mathrm{CDCl}_{3}$

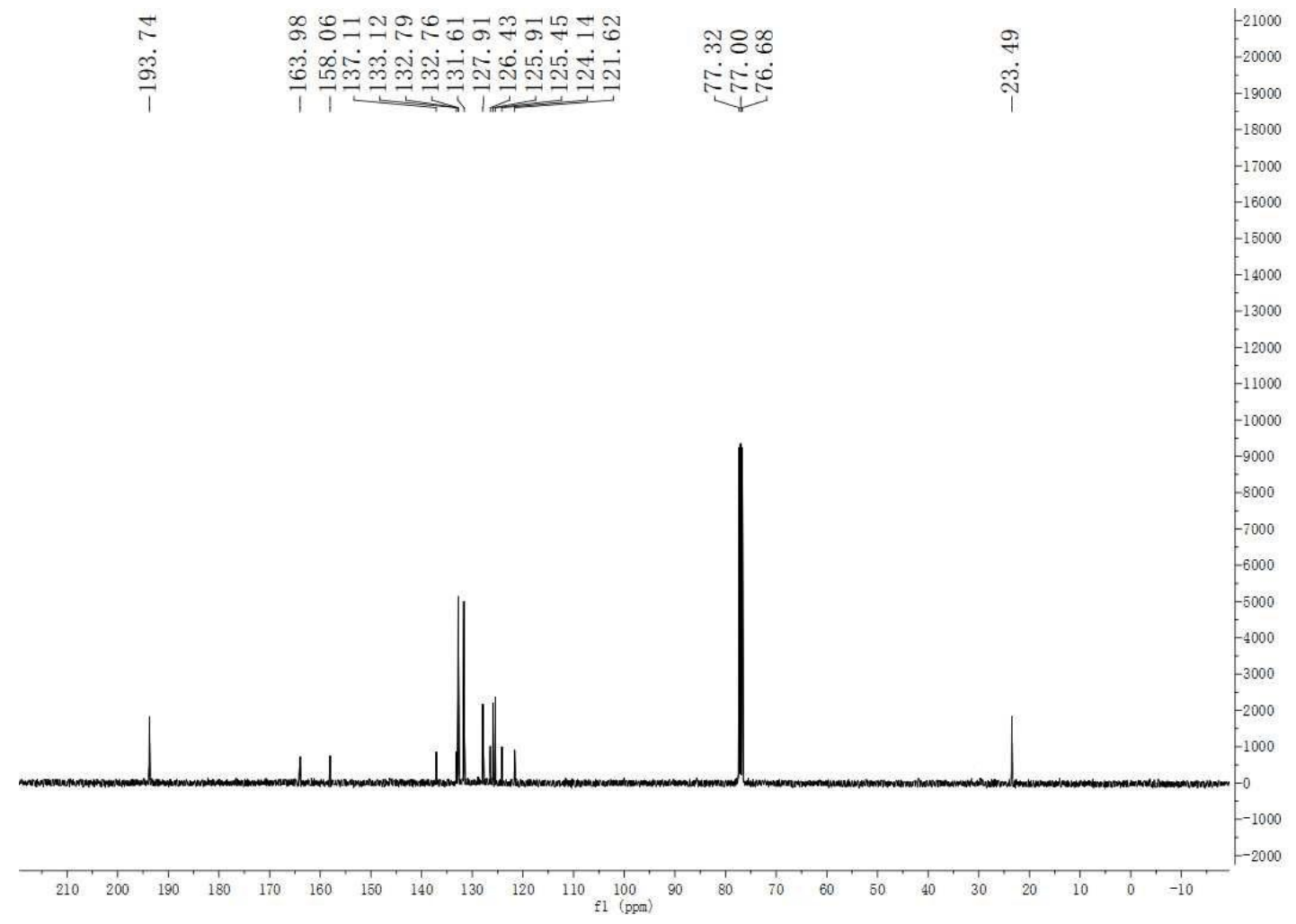

Figure S70. $100 \mathrm{MHz}{ }^{13} \mathrm{C}\left\{{ }^{1} \mathrm{H}\right\}$ NMR spectrum of $\mathbf{4 j}$ in $\mathrm{CDCl}_{3}$. 


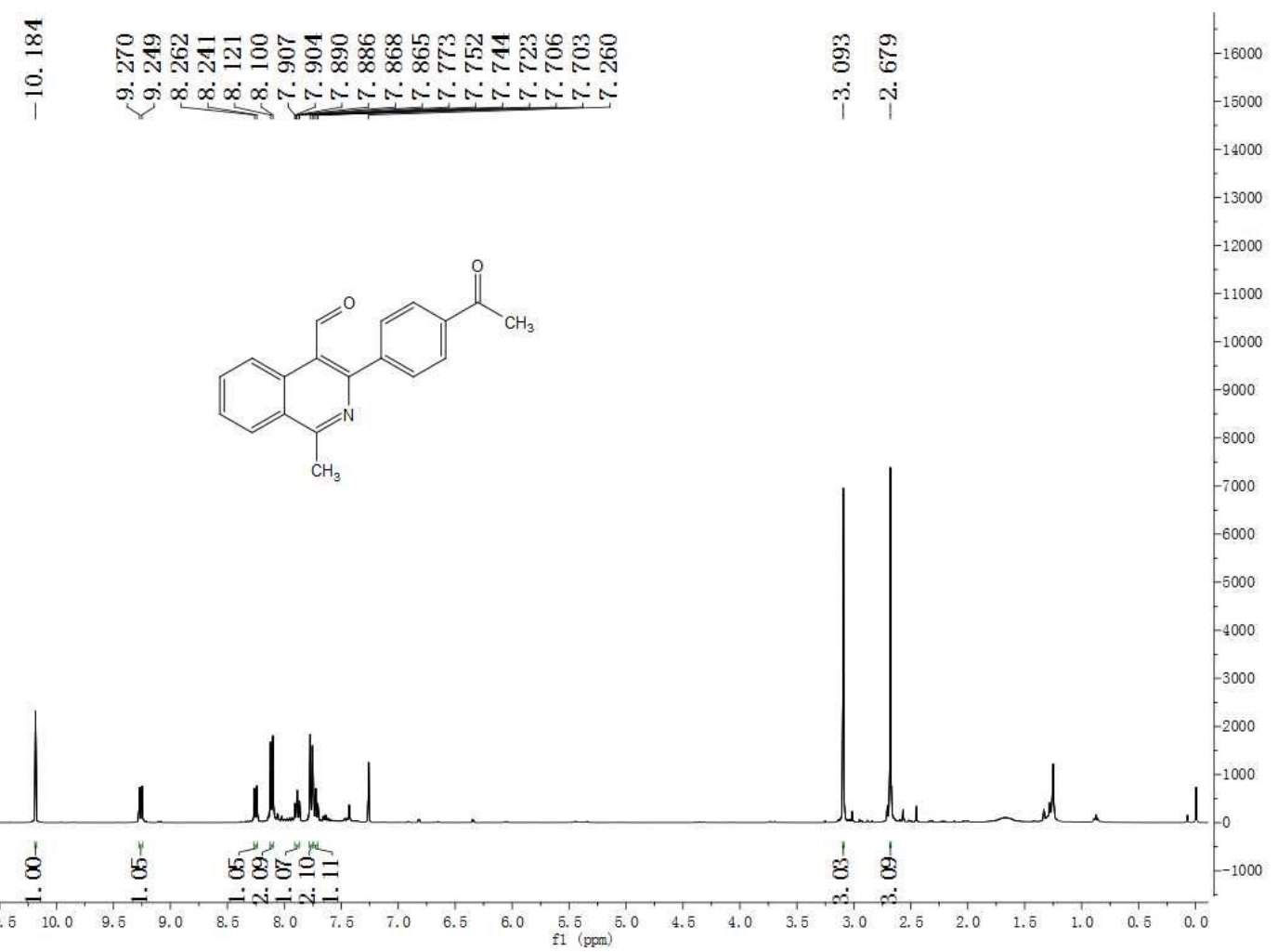

Figure S71. $400 \mathrm{MHz}{ }^{1} \mathrm{H} \mathrm{NMR}$ spectrum of $\mathbf{4 k}$ in $\mathrm{CDCl}_{3}$

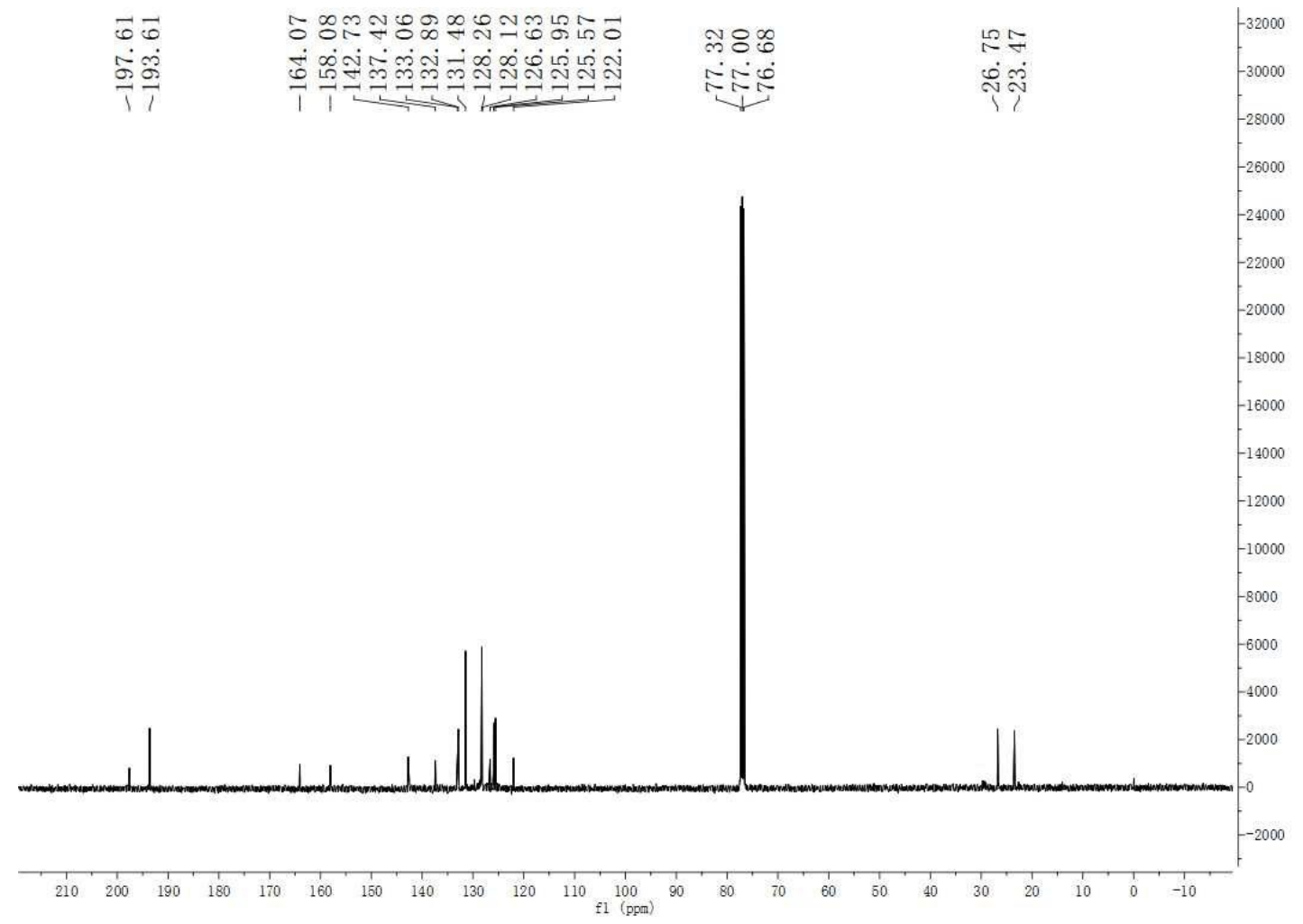

Figure S72. $100 \mathrm{MHz}{ }^{13} \mathrm{C}\left\{{ }^{1} \mathrm{H}\right\}$ NMR spectrum of $\mathbf{4 k}$ in $\mathrm{CDCl}_{3}$. 


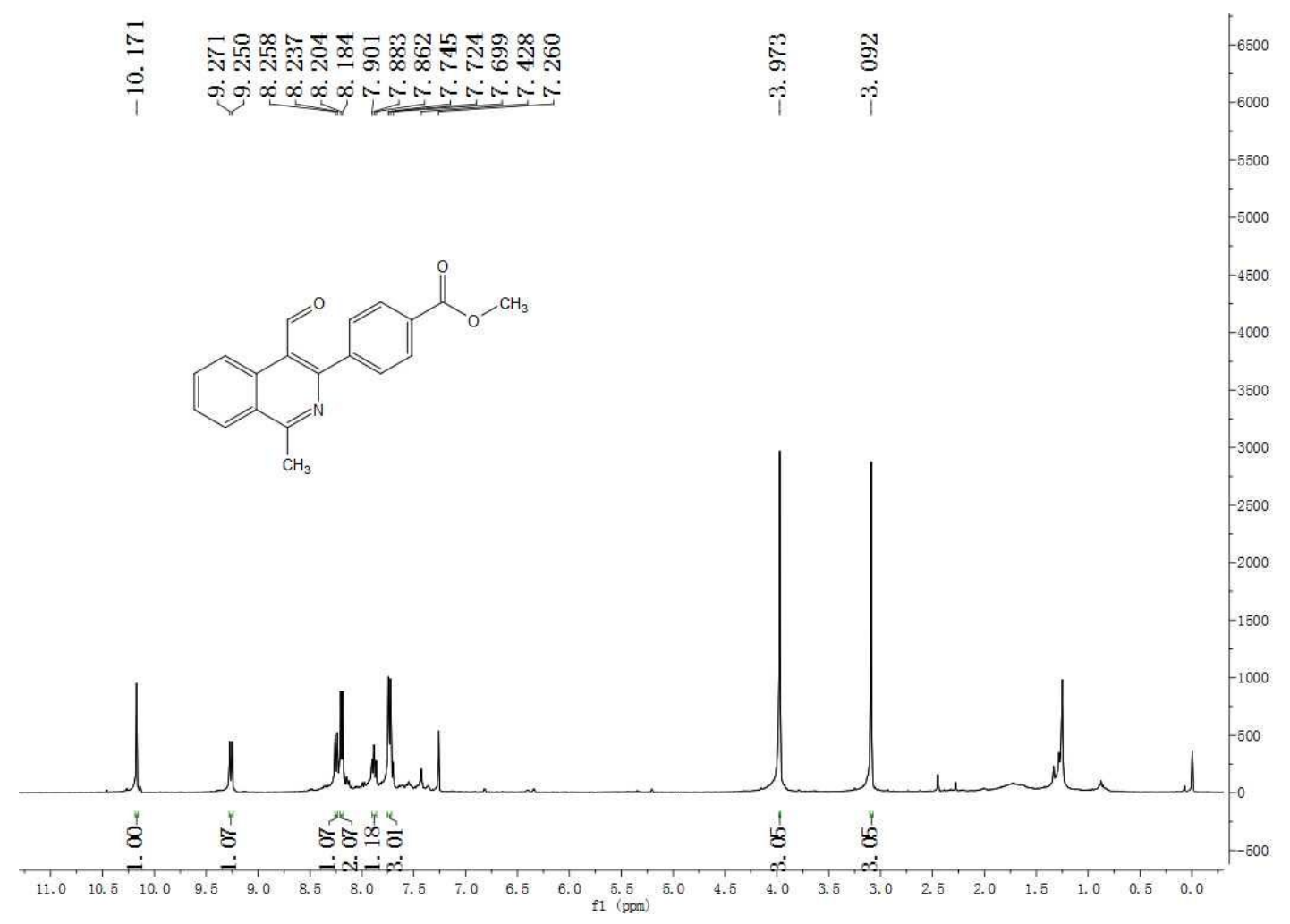

Figure S73. $400 \mathrm{MHz}^{1} \mathrm{H}$ NMR spectrum of $4 \mathbf{l}$ in $\mathrm{CDCl}_{3}$

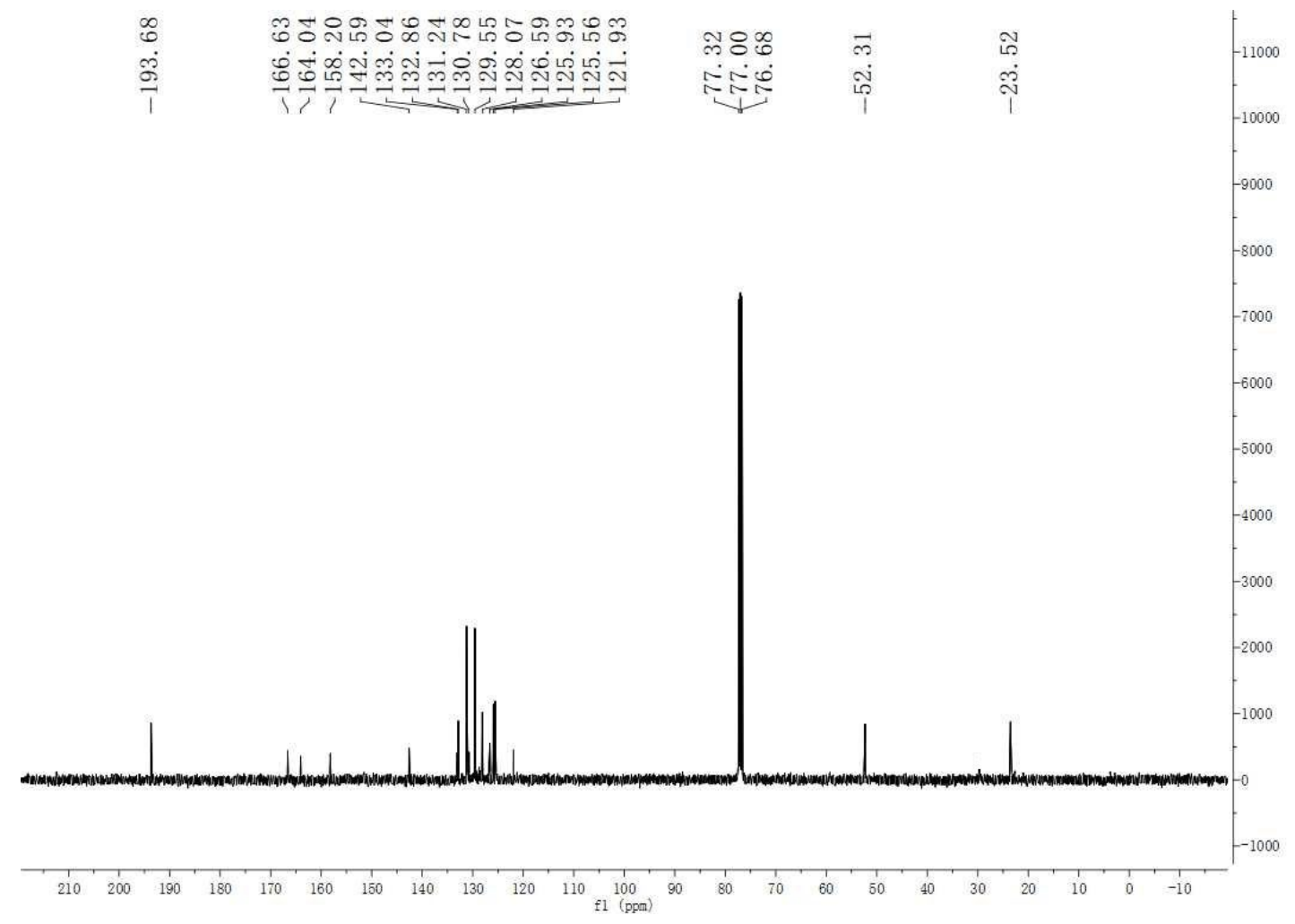

Figure S74. $100 \mathrm{MHz}{ }^{13} \mathrm{C}\left\{{ }^{1} \mathrm{H}\right\} \mathrm{NMR}$ spectrum of $4 \mathrm{l}$ in $\mathrm{CDCl}_{3}$. 


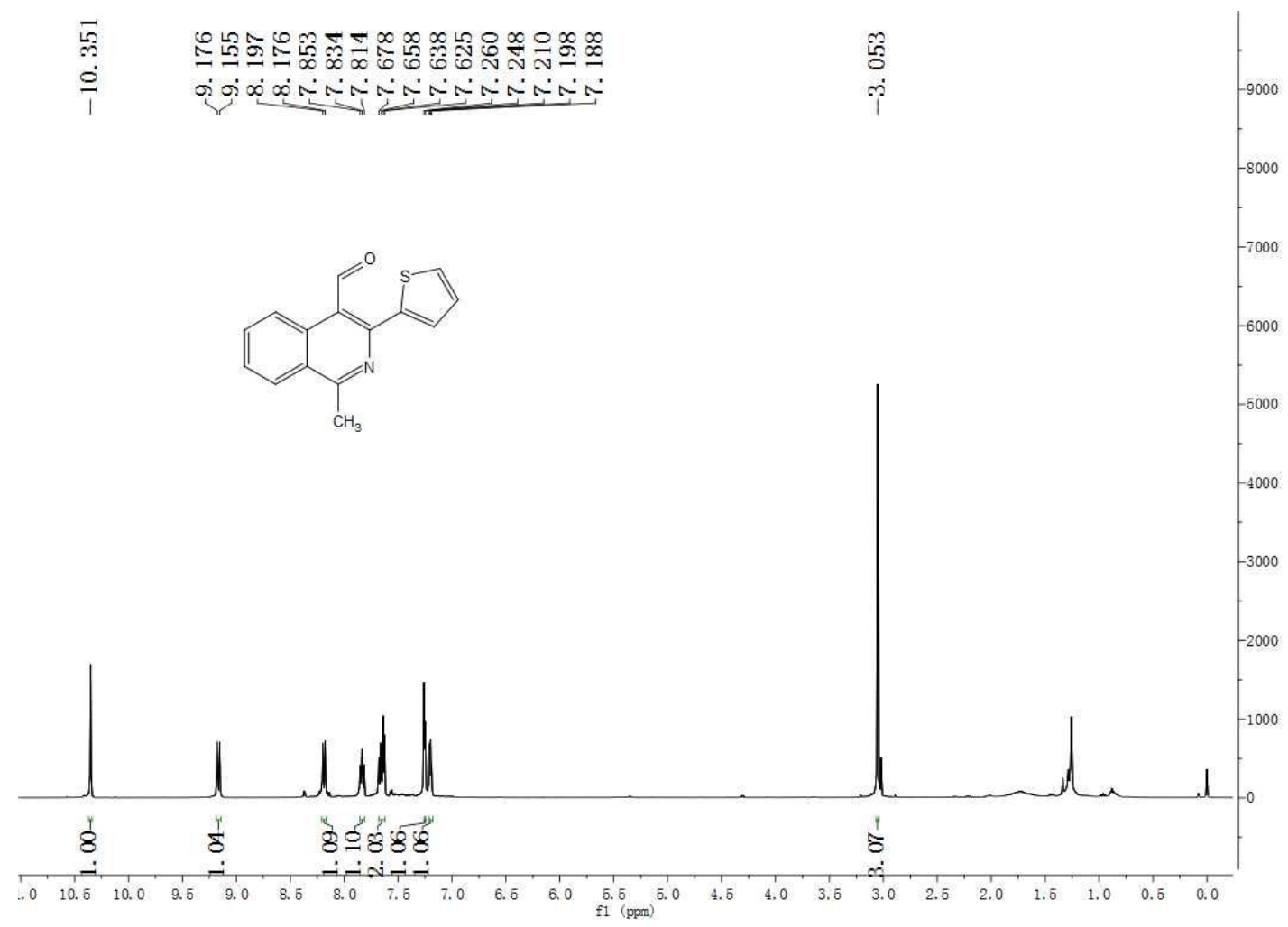

Figure S75. $400 \mathrm{MHz}{ }^{1} \mathrm{H}$ NMR spectrum of $\mathbf{4 m}$ in $\mathrm{CDCl}_{3}$

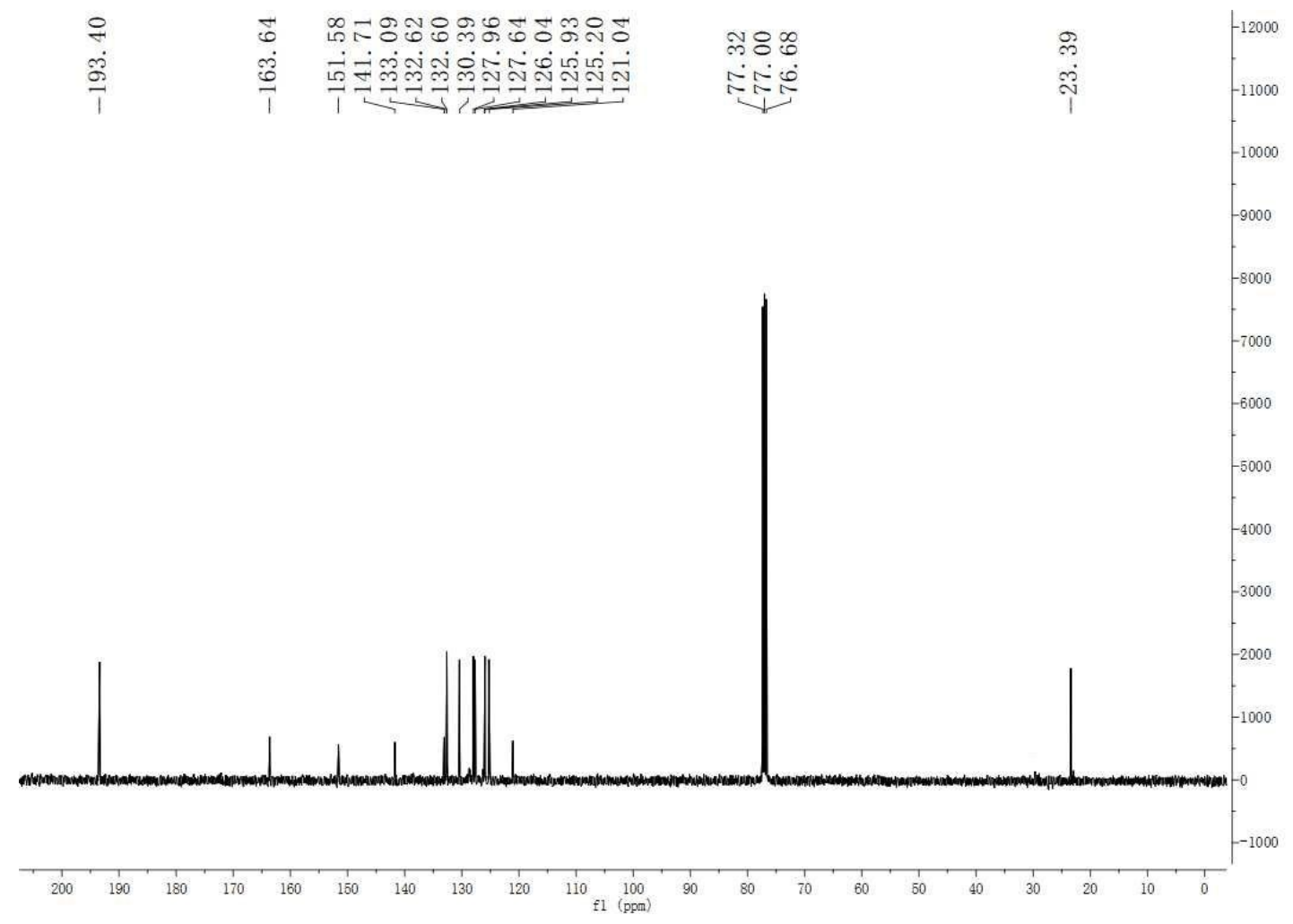

Figure S76. $100 \mathrm{MHz}{ }^{13} \mathrm{C}\left\{{ }^{1} \mathrm{H}\right\} \mathrm{NMR}$ spectrum of $\mathbf{4 m}$ in $\mathrm{CDCl}_{3}$. 


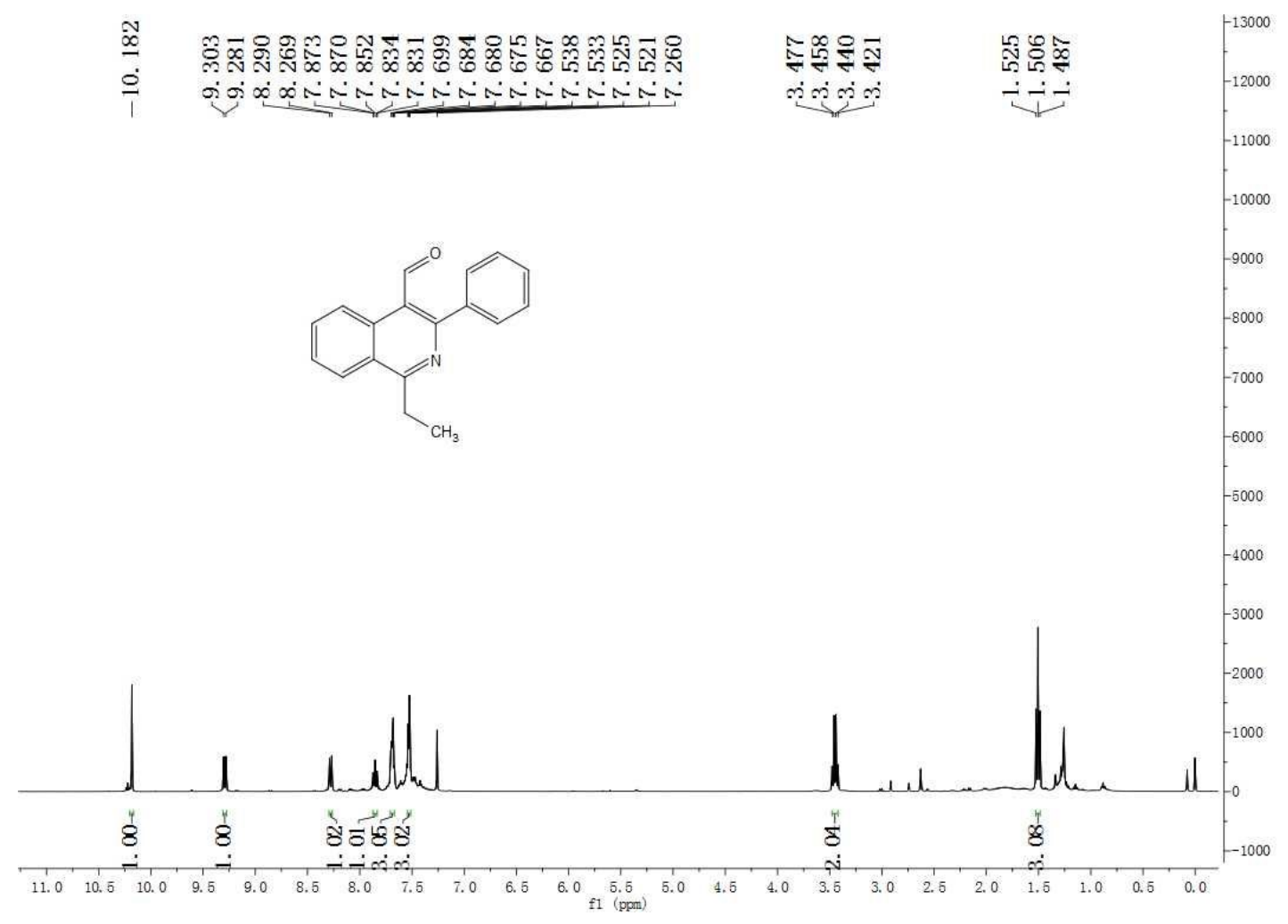

Figure S77. $400 \mathrm{MHz}{ }^{1} \mathrm{H}$ NMR spectrum of $\mathbf{4 n}$ in $\mathrm{CDCl}_{3}$

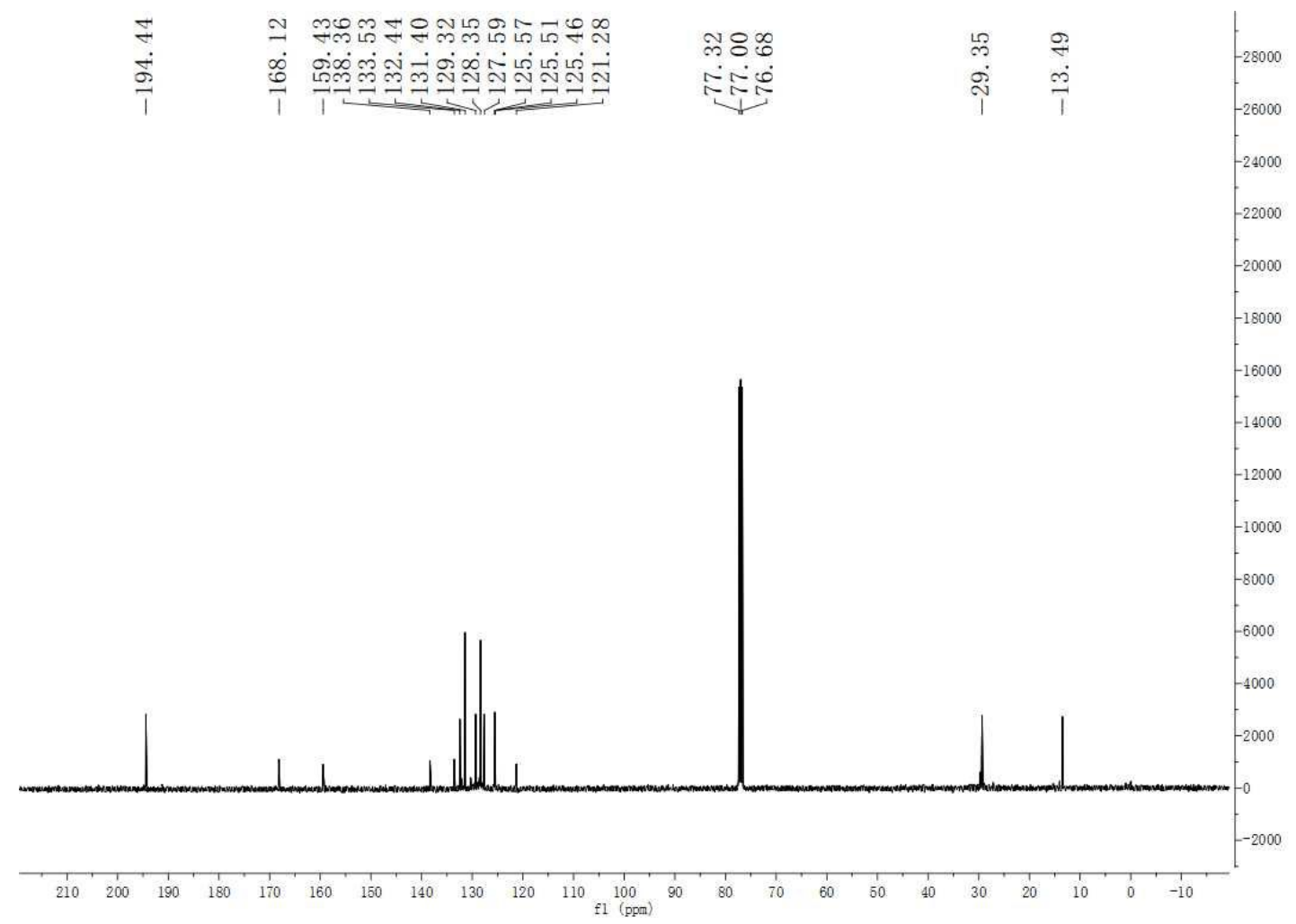

Figure S78. $100 \mathrm{MHz}{ }^{13} \mathrm{C}\left\{{ }^{1} \mathrm{H}\right\}$ NMR spectrum of $\mathbf{4 n}$ in $\mathrm{CDCl}_{3}$. 


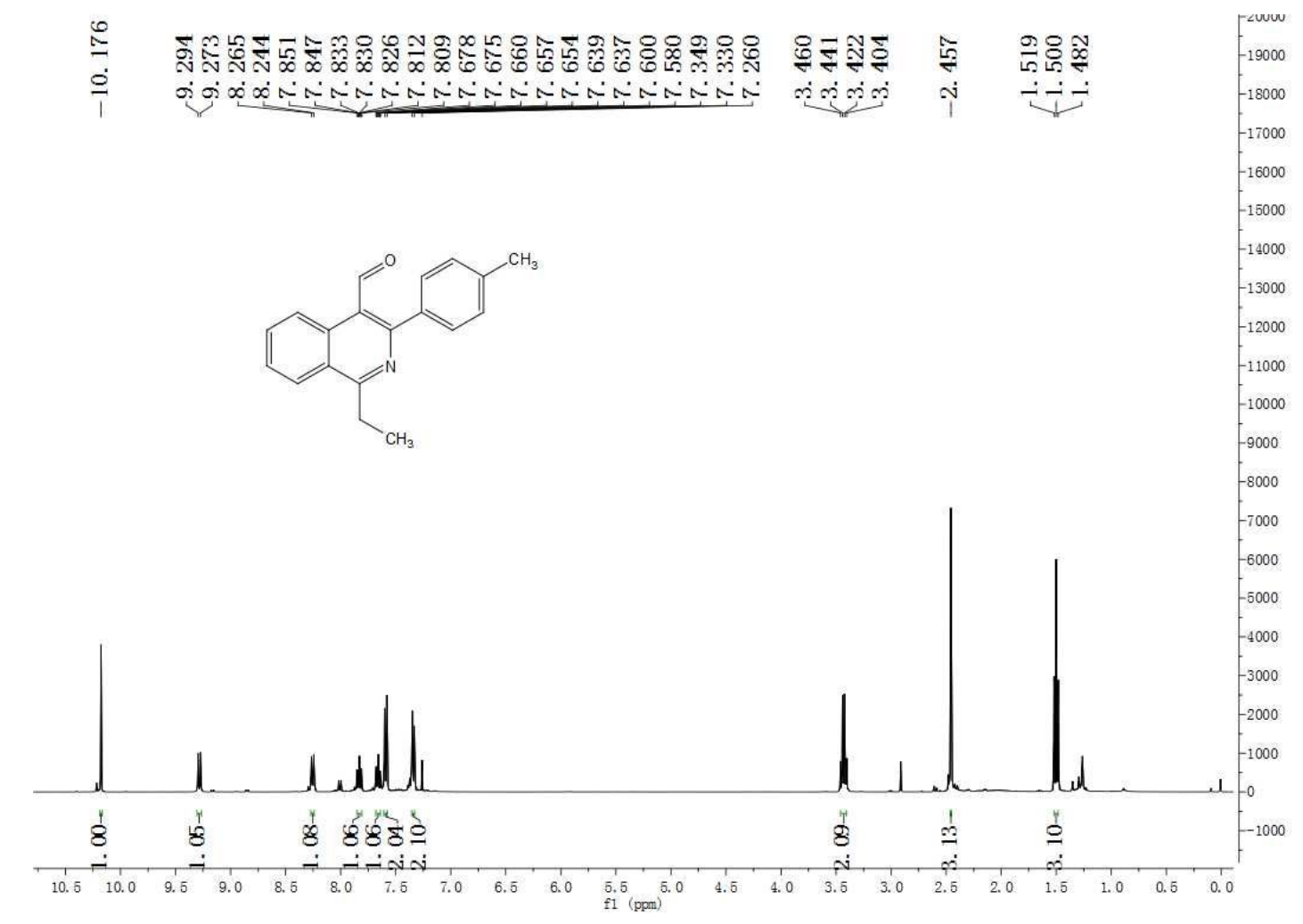

Figure S79. $400 \mathrm{MHz}{ }^{1} \mathrm{H}$ NMR spectrum of 40 in $\mathrm{CDCl}_{3}$

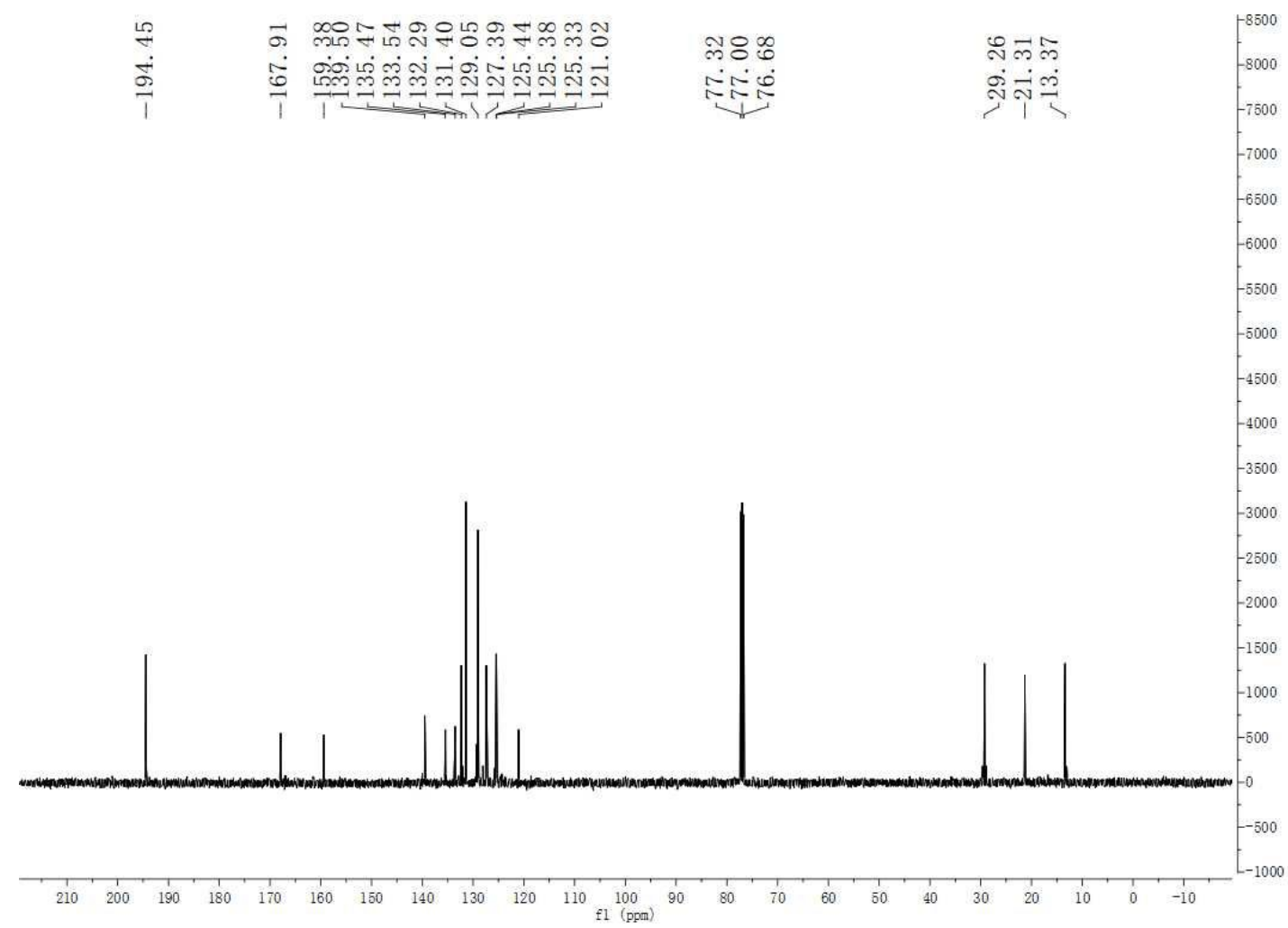

Figure S80. $100 \mathrm{MHz}{ }^{13} \mathrm{C}\left\{{ }^{1} \mathrm{H}\right\}$ NMR spectrum of 40 in $\mathrm{CDCl}_{3}$. 


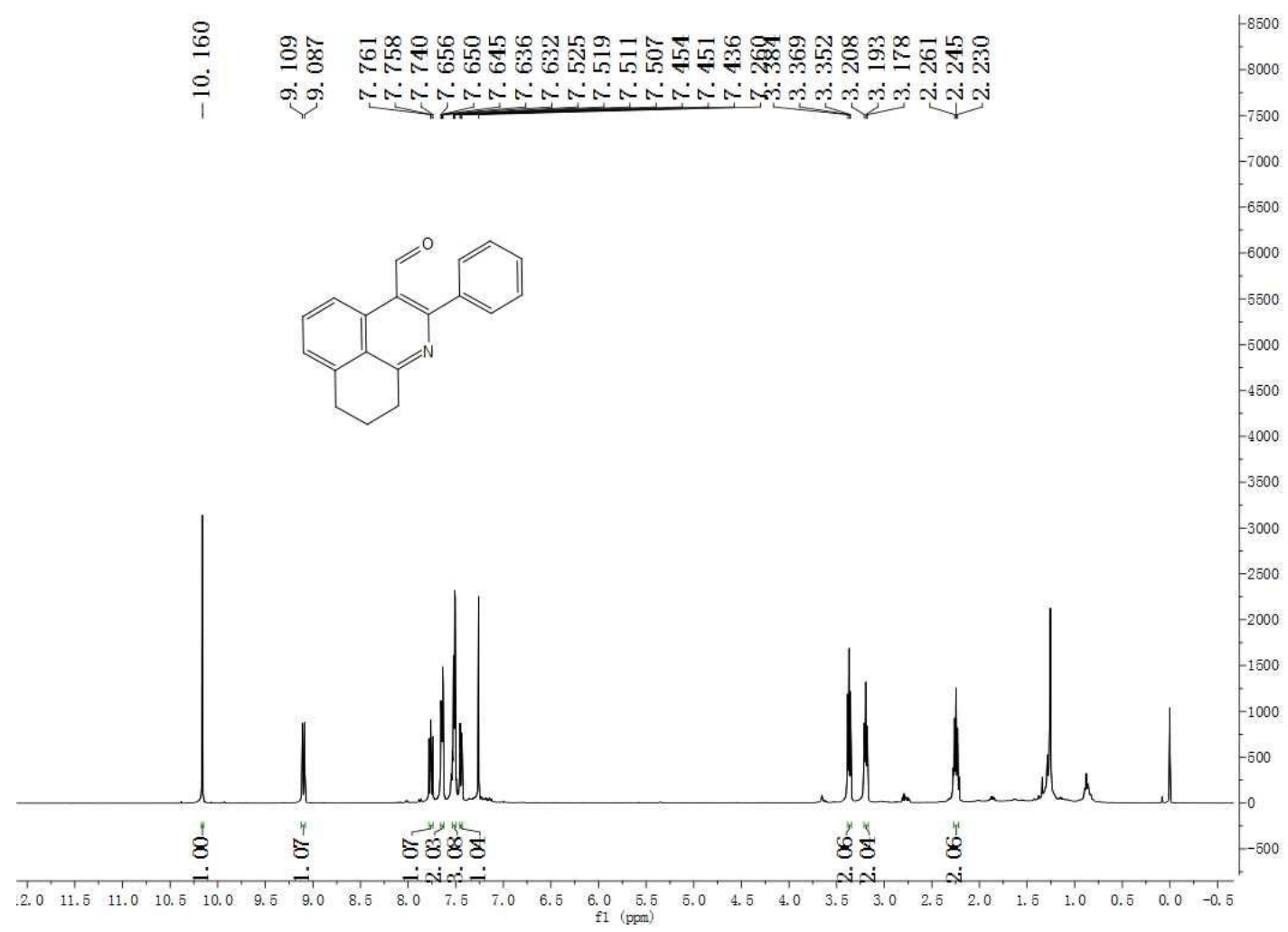

Figure S81. $400 \mathrm{MHz}{ }^{1} \mathrm{H} \mathrm{NMR}$ spectrum of $\mathbf{4 p}$ in $\mathrm{CDCl}_{3}$

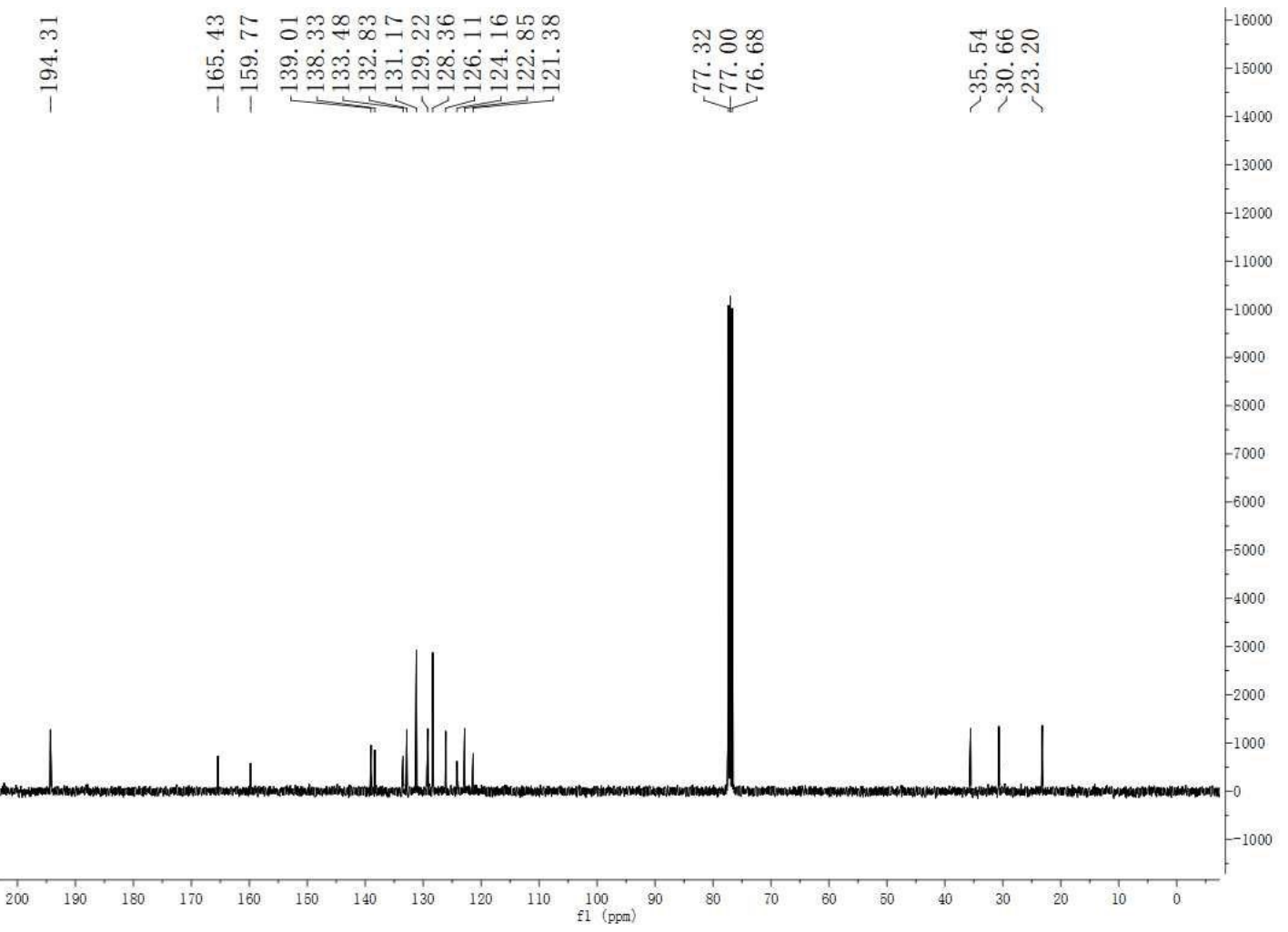

Figure S82. $100 \mathrm{MHz}{ }^{13} \mathrm{C}\left\{{ }^{1} \mathrm{H}\right\} \mathrm{NMR}$ spectrum of $\mathbf{4 p}$ in $\mathrm{CDCl}_{3}$. 


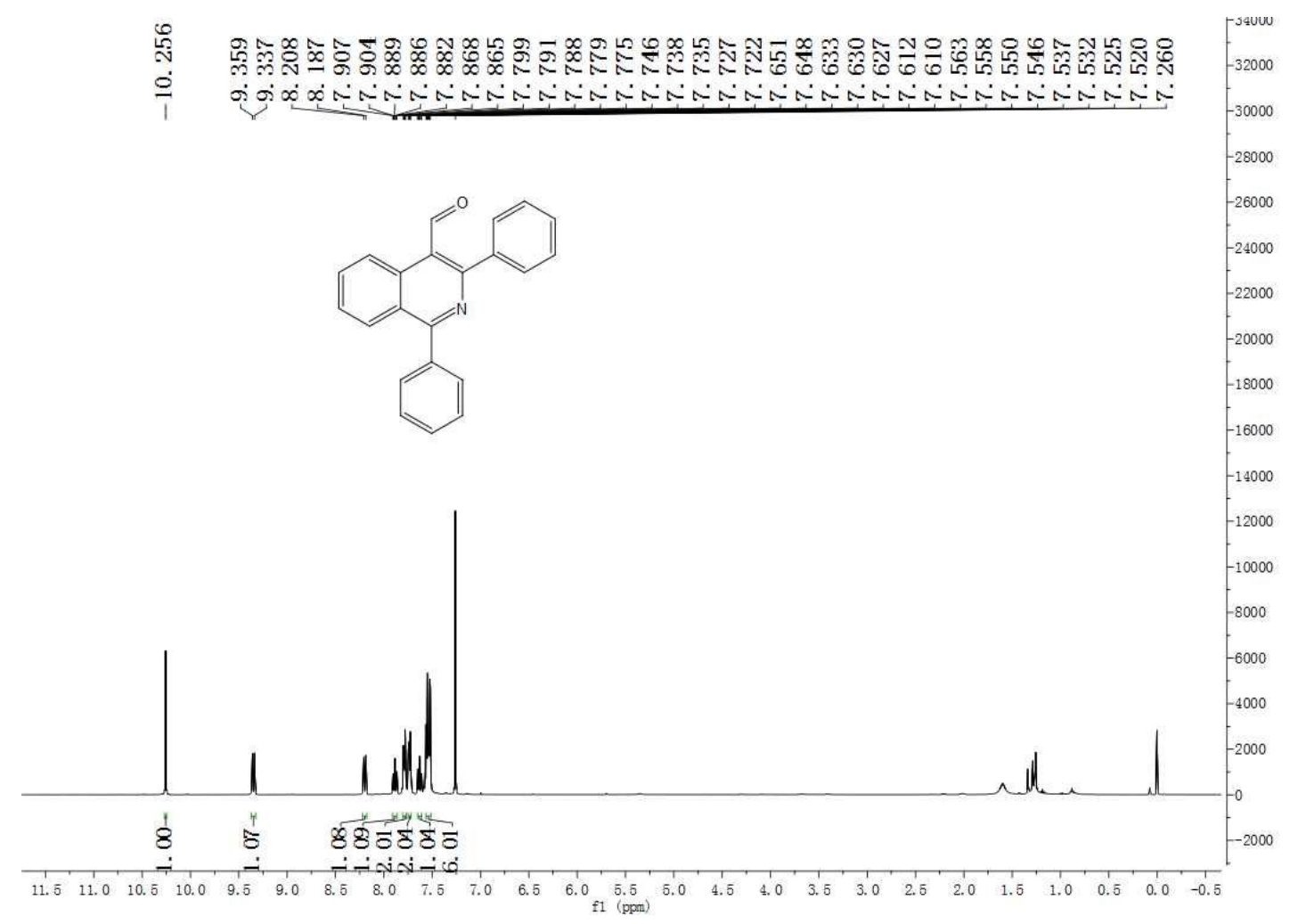

Figure S83. $400 \mathrm{MHz}{ }^{1} \mathrm{H} \mathrm{NMR}$ spectrum of $\mathbf{4 q}$ in $\mathrm{CDCl}_{3}$

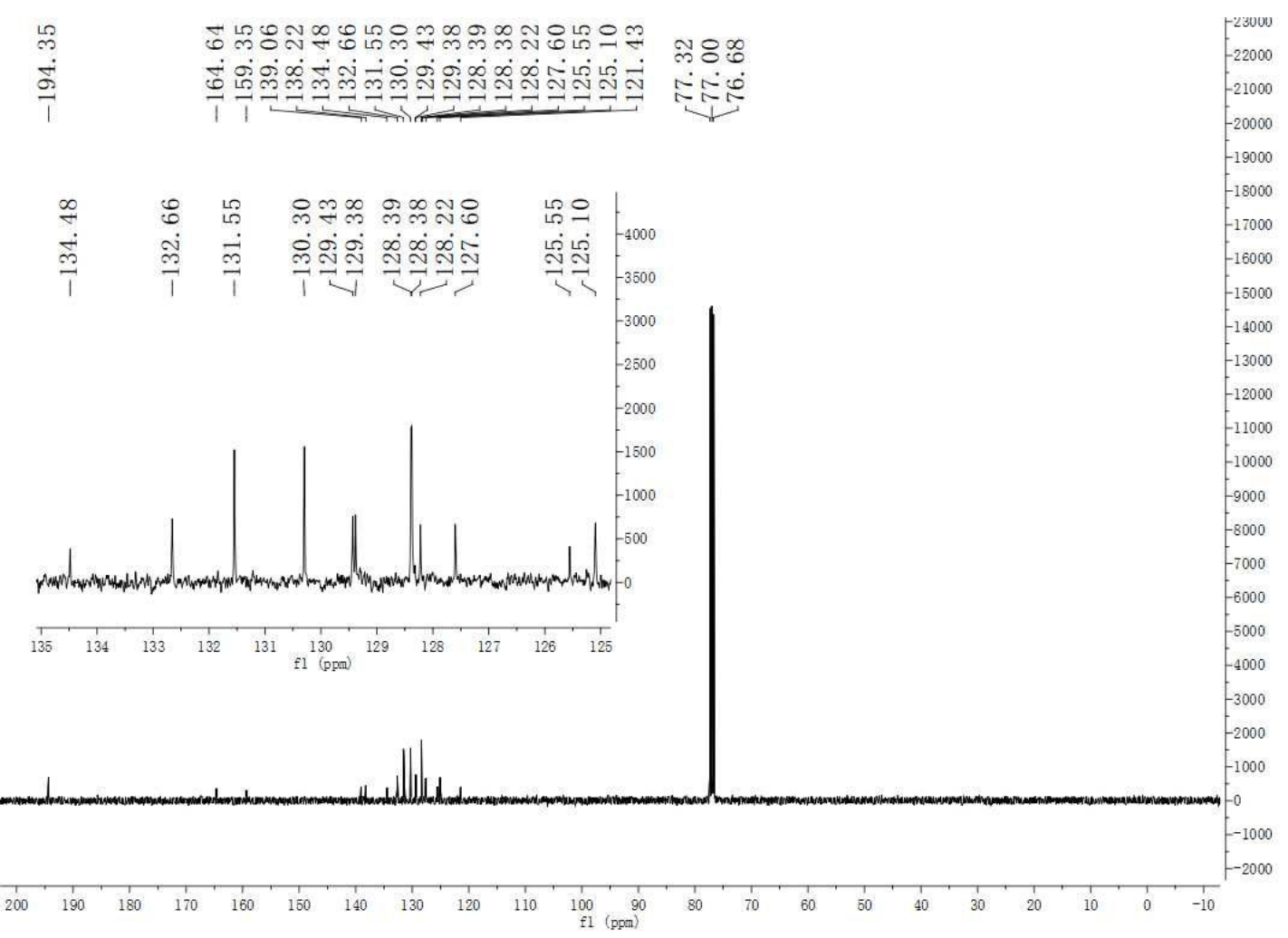

Figure S84. $100 \mathrm{MHz}{ }^{13} \mathrm{C}\left\{{ }^{1} \mathrm{H}\right\}$ NMR spectrum of $\mathbf{4 q}$ in $\mathrm{CDCl}_{3}$. 


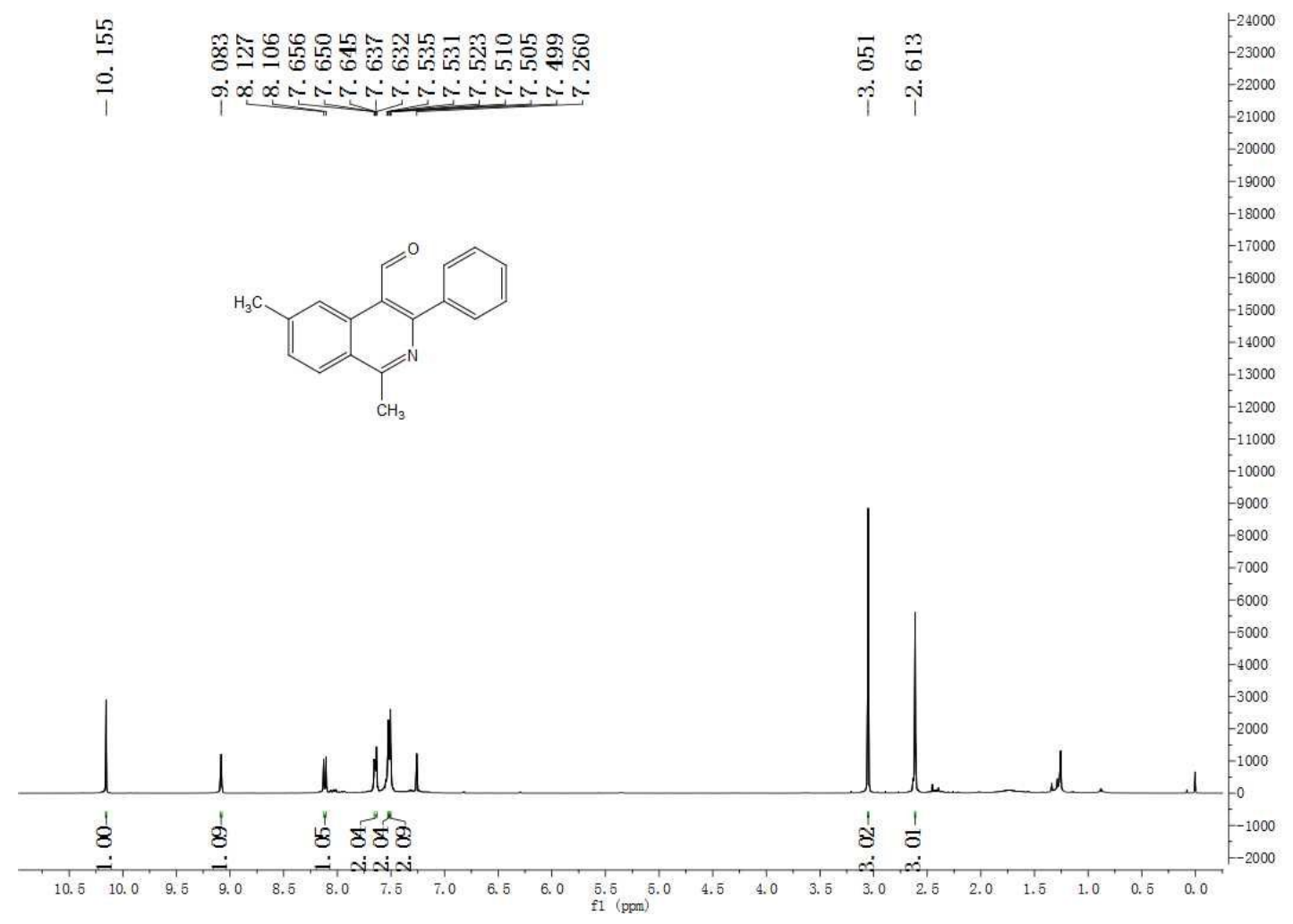

Figure S85. $400 \mathrm{MHz}{ }^{1} \mathrm{H}$ NMR spectrum of $\mathbf{4 r}$ in $\mathrm{CDCl}_{3}$

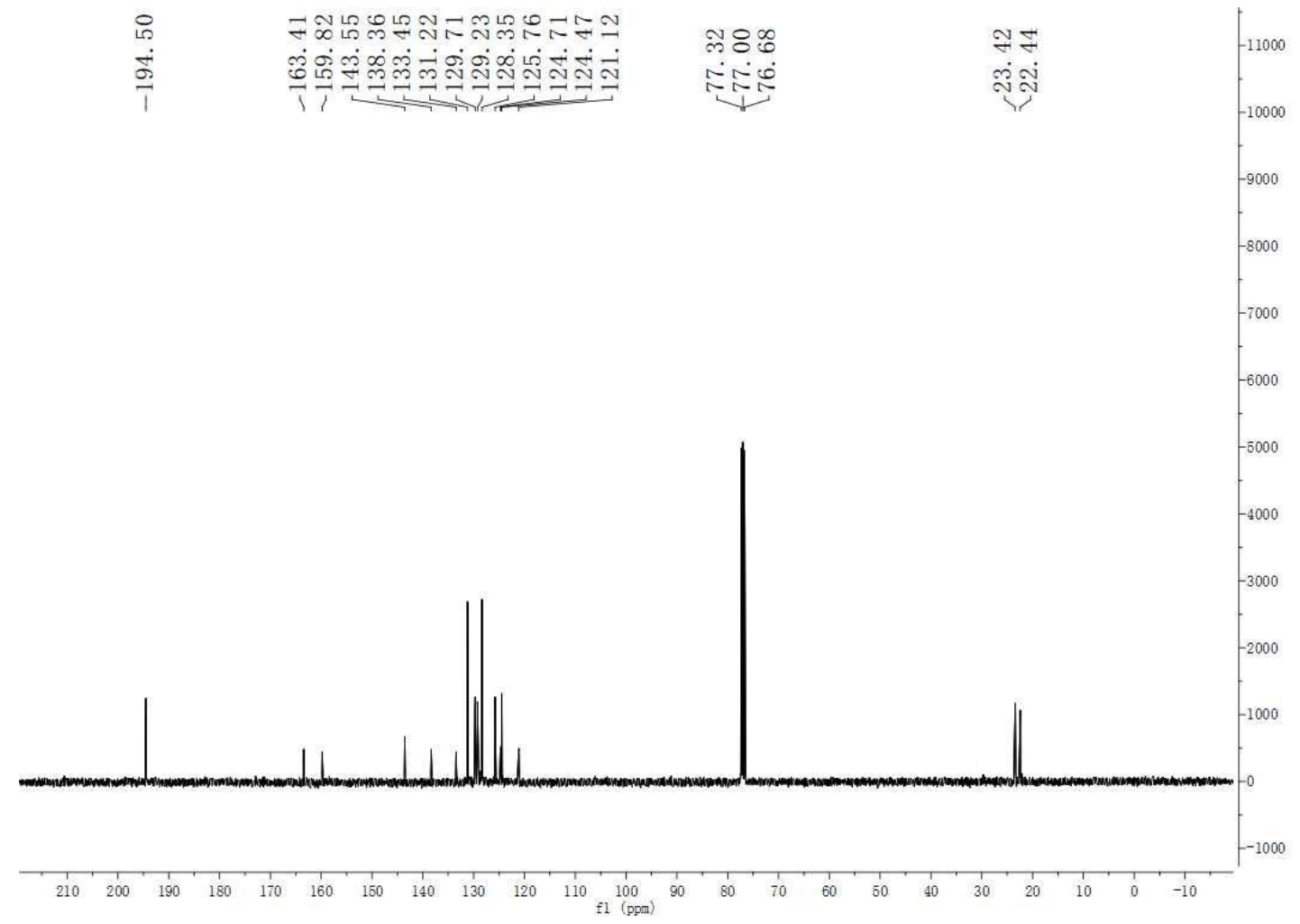

Figure S86. $100 \mathrm{MHz}{ }^{13} \mathrm{C}\left\{{ }^{1} \mathrm{H}\right\}$ NMR spectrum of $4 \mathbf{r}$ in $\mathrm{CDCl}_{3}$. 


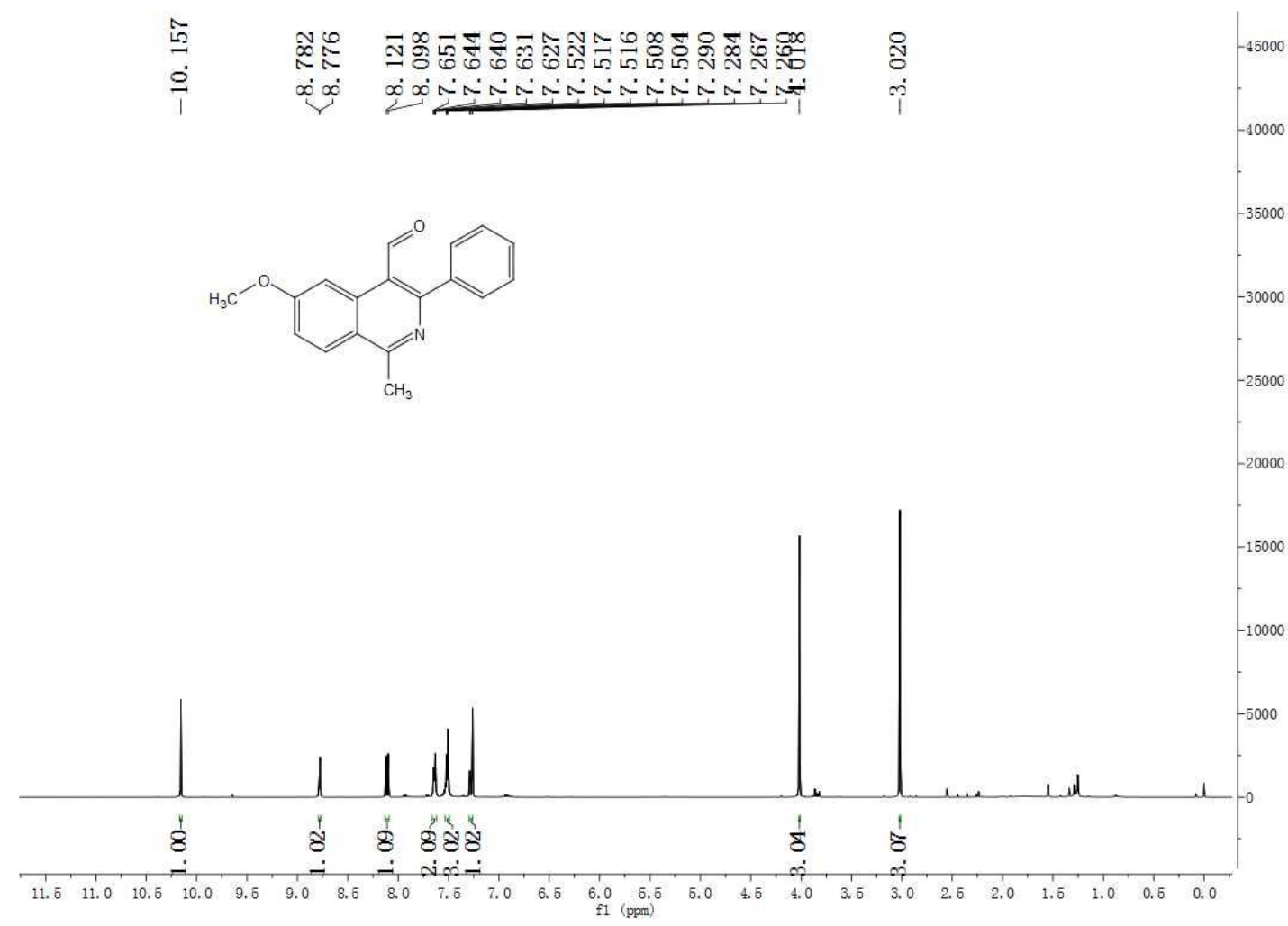

Figure S87. $400 \mathrm{MHz}{ }^{1} \mathrm{H}$ NMR spectrum of $4 \mathbf{s}$ in $\mathrm{CDCl}_{3}$

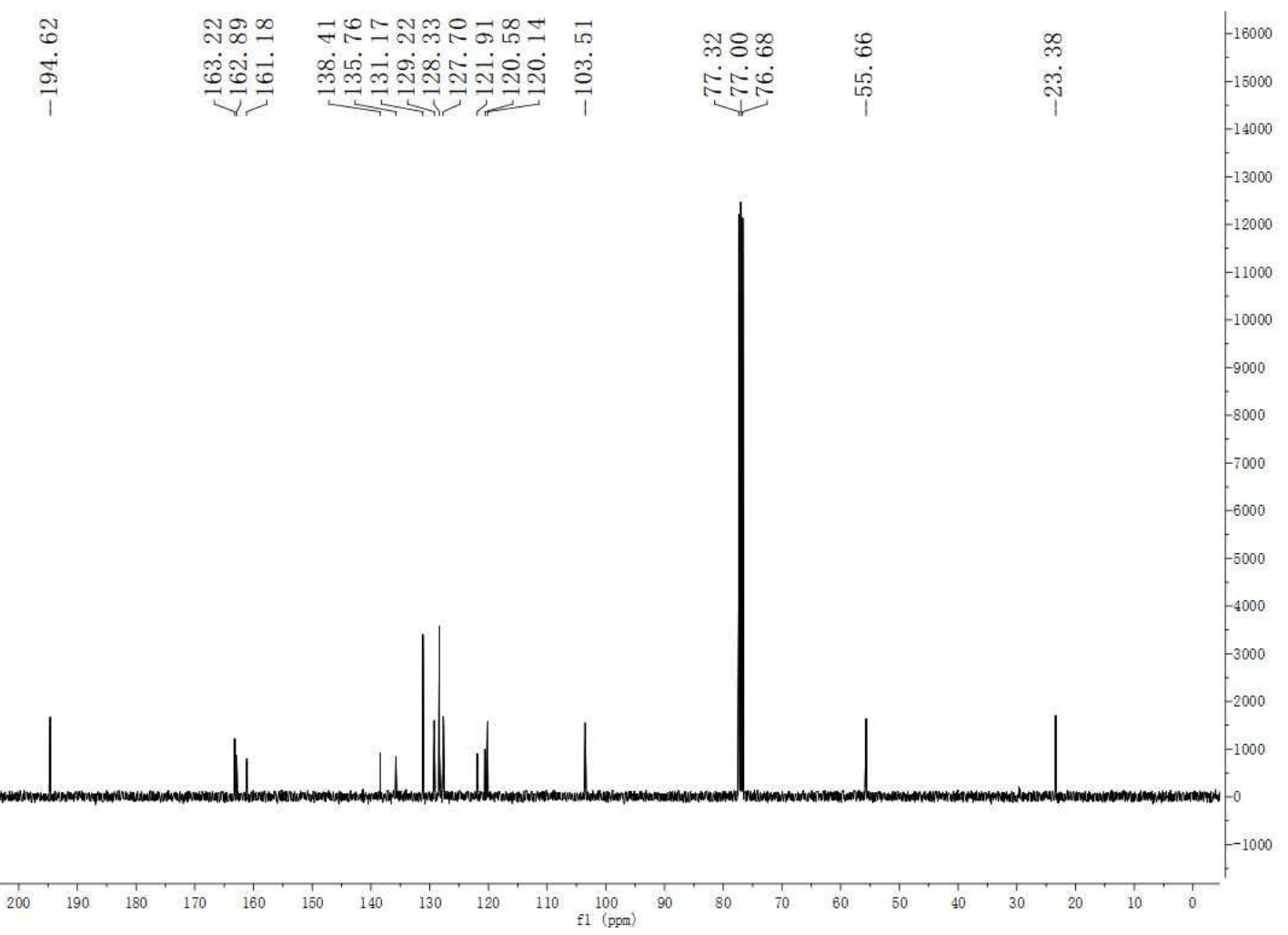

Figure S88. $100 \mathrm{MHz}{ }^{13} \mathrm{C}\left\{{ }^{1} \mathrm{H}\right\}$ NMR spectrum of $4 \mathbf{s}$ in $\mathrm{CDCl}_{3}$. 


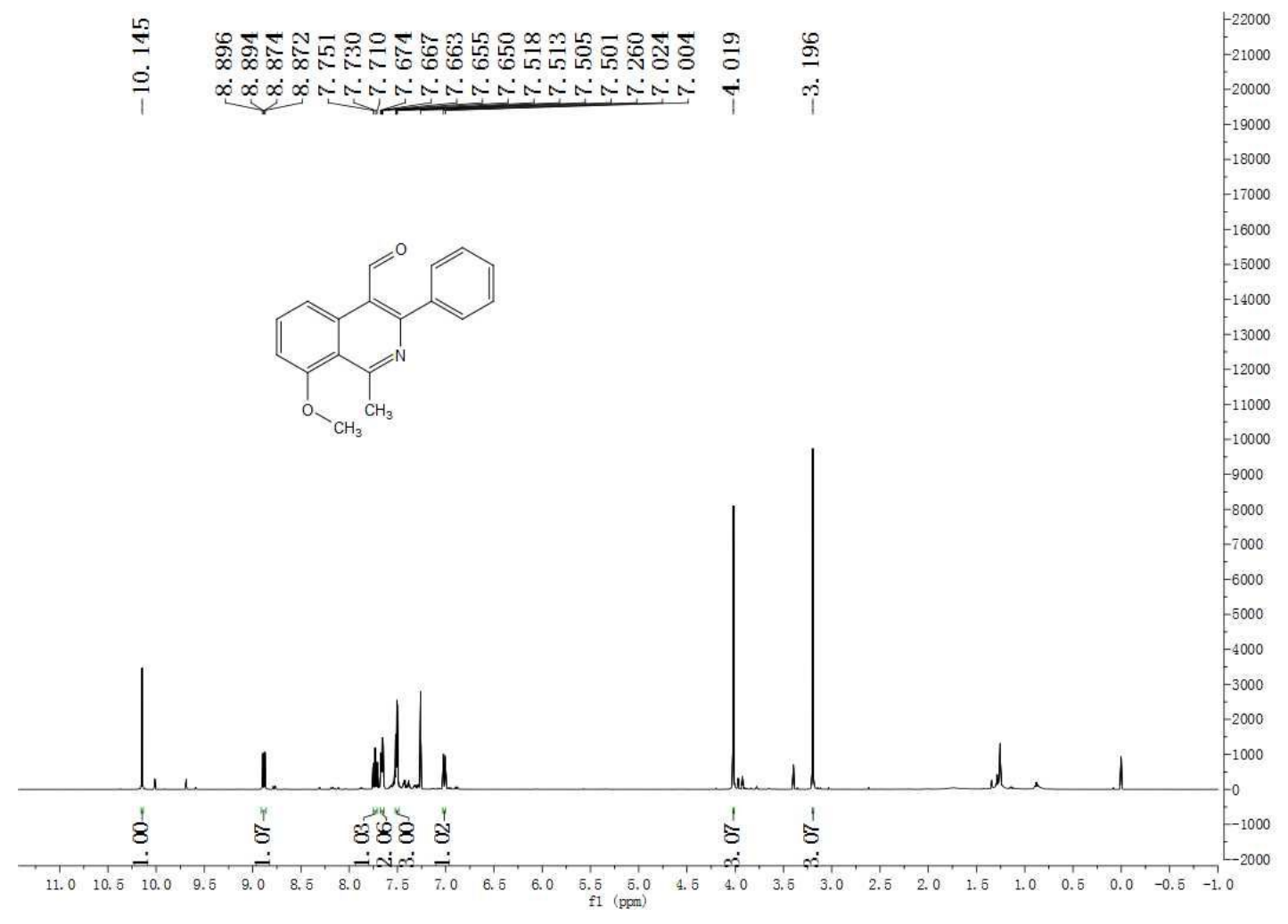

Figure S89. $400 \mathrm{MHz}{ }^{1} \mathrm{H}$ NMR spectrum of $\mathbf{4 t}$ in $\mathrm{CDCl}_{3}$

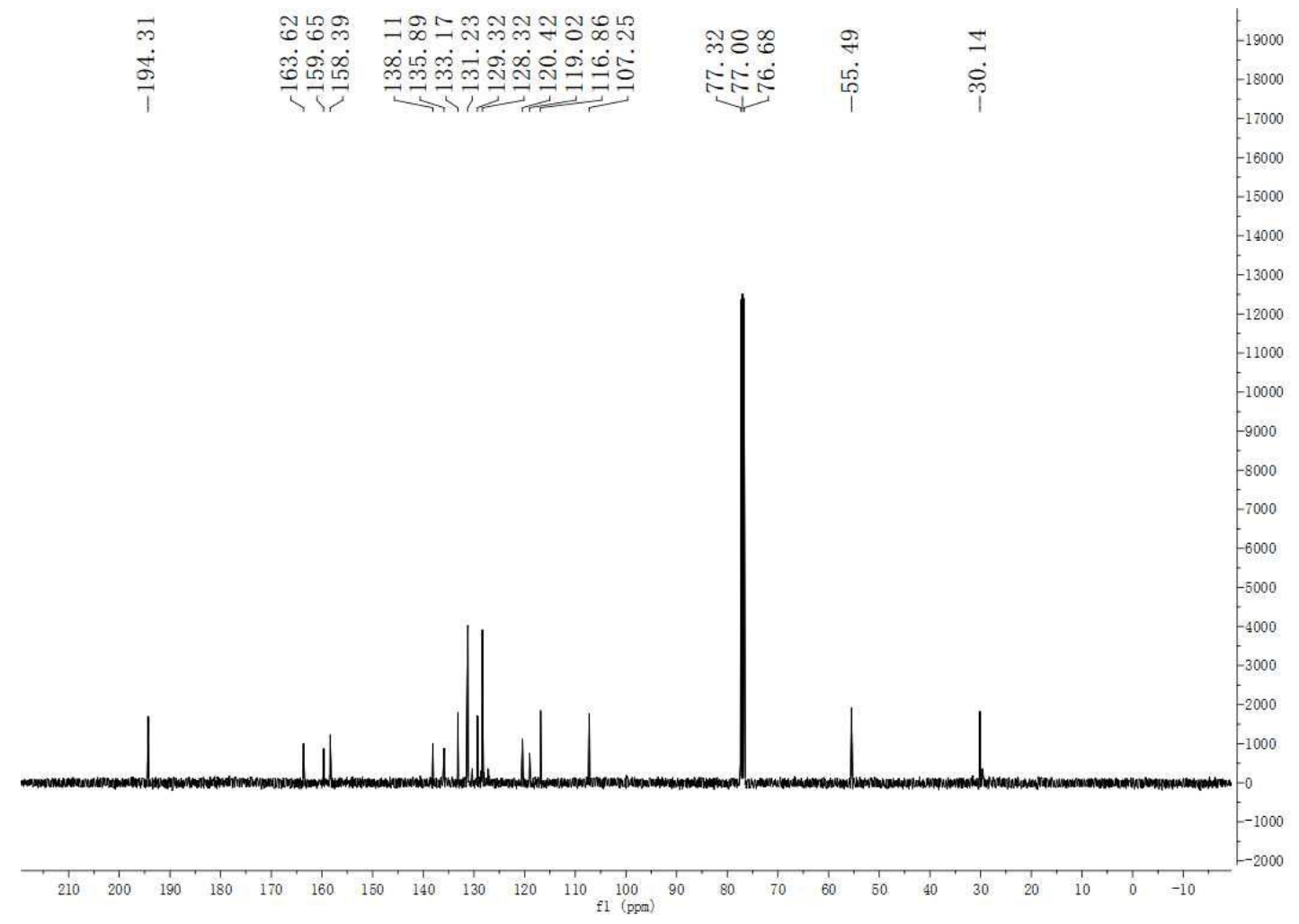

Figure S90. $100 \mathrm{MHz}{ }^{13} \mathrm{C}\left\{{ }^{1} \mathrm{H}\right\}$ NMR spectrum of $\mathbf{4 t}$ in $\mathrm{CDCl}_{3}$. 


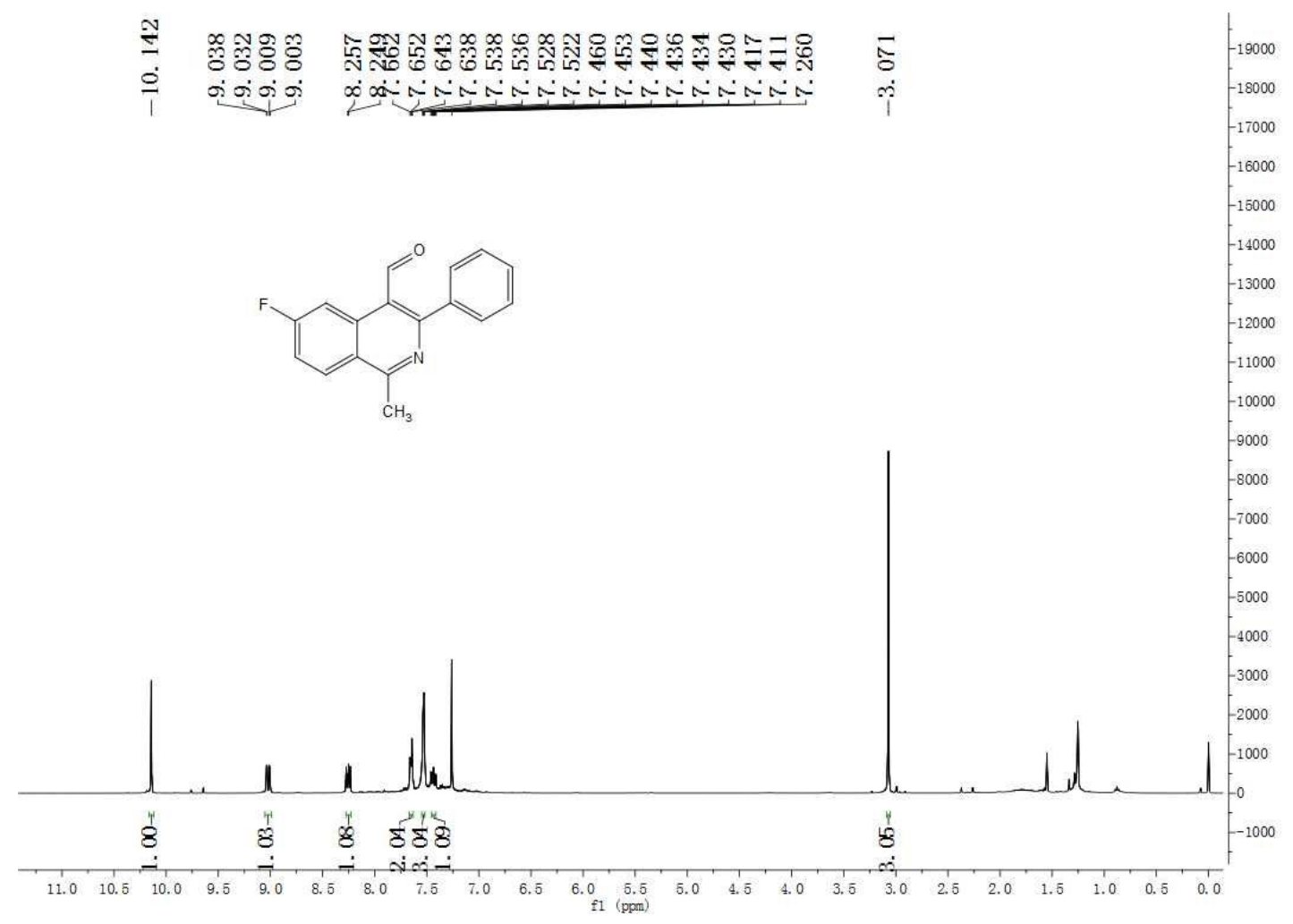

Figure S91. $400 \mathrm{MHz}{ }^{1} \mathrm{H} \mathrm{NMR}$ spectrum of $\mathbf{4} \mathbf{u}$ in $\mathrm{CDCl}_{3}$

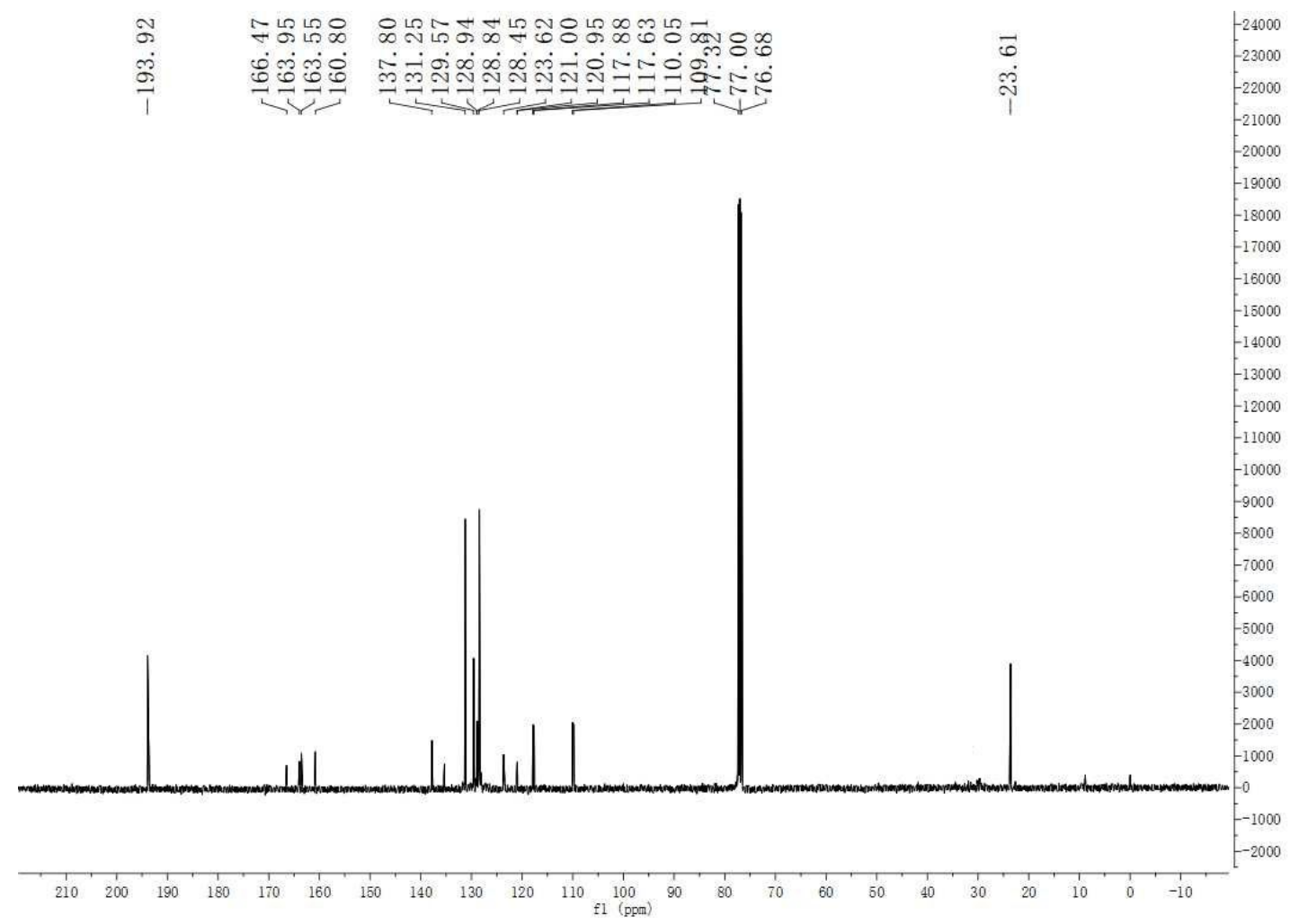

Figure S92. $100 \mathrm{MHz}{ }^{13} \mathrm{C}\left\{{ }^{1} \mathrm{H}\right\} \mathrm{NMR}$ spectrum of $\mathbf{4 u}$ in $\mathrm{CDCl}_{3}$. 


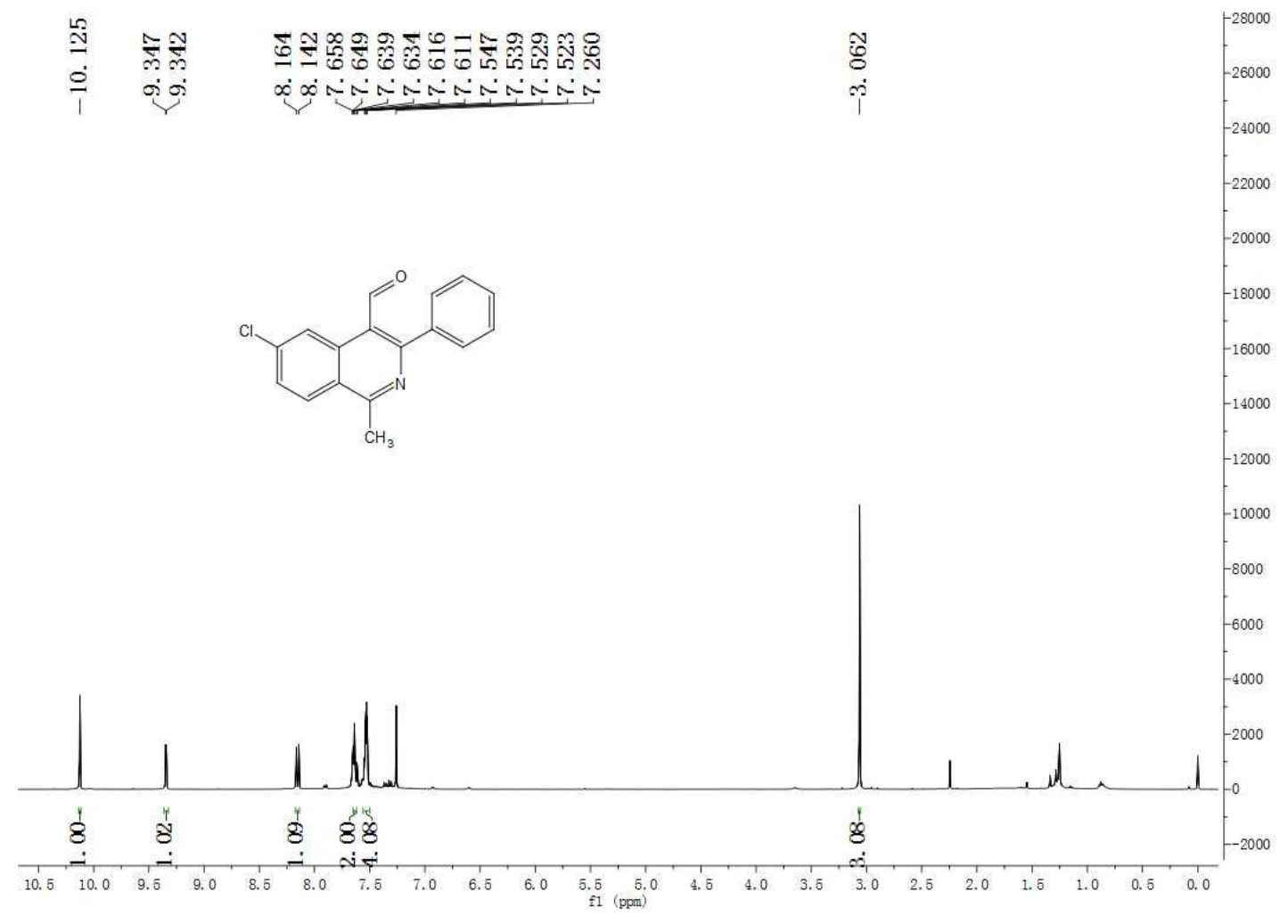

Figure S93. $400 \mathrm{MHz}{ }^{1} \mathrm{H}$ NMR spectrum of $\mathbf{4} \mathbf{v}$ in $\mathrm{CDCl}_{3}$

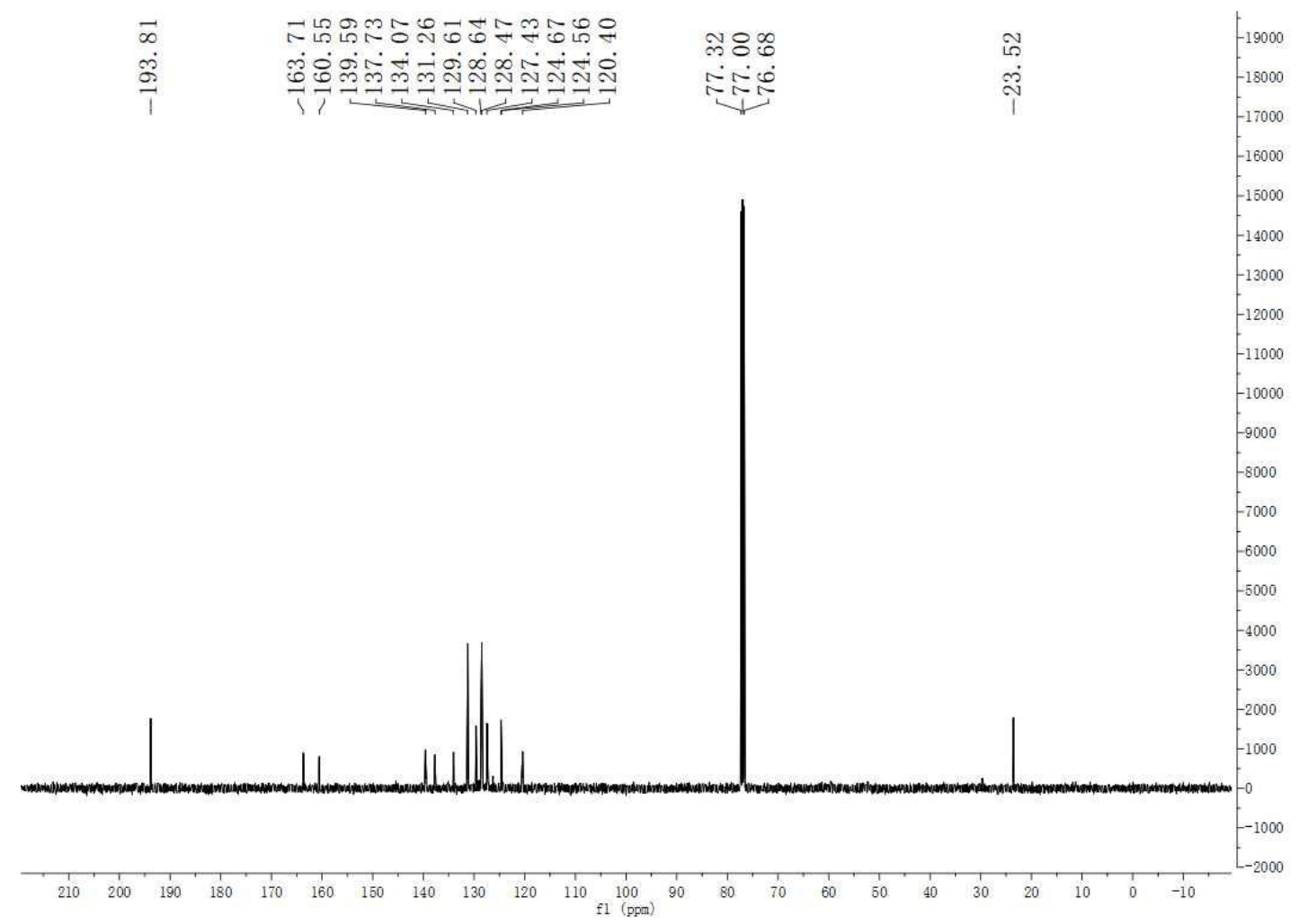

Figure S94. $100 \mathrm{MHz}{ }^{13} \mathrm{C}\left\{{ }^{1} \mathrm{H}\right\} \mathrm{NMR}$ spectrum of $\mathbf{4 v}$ in $\mathrm{CDCl}_{3}$. 


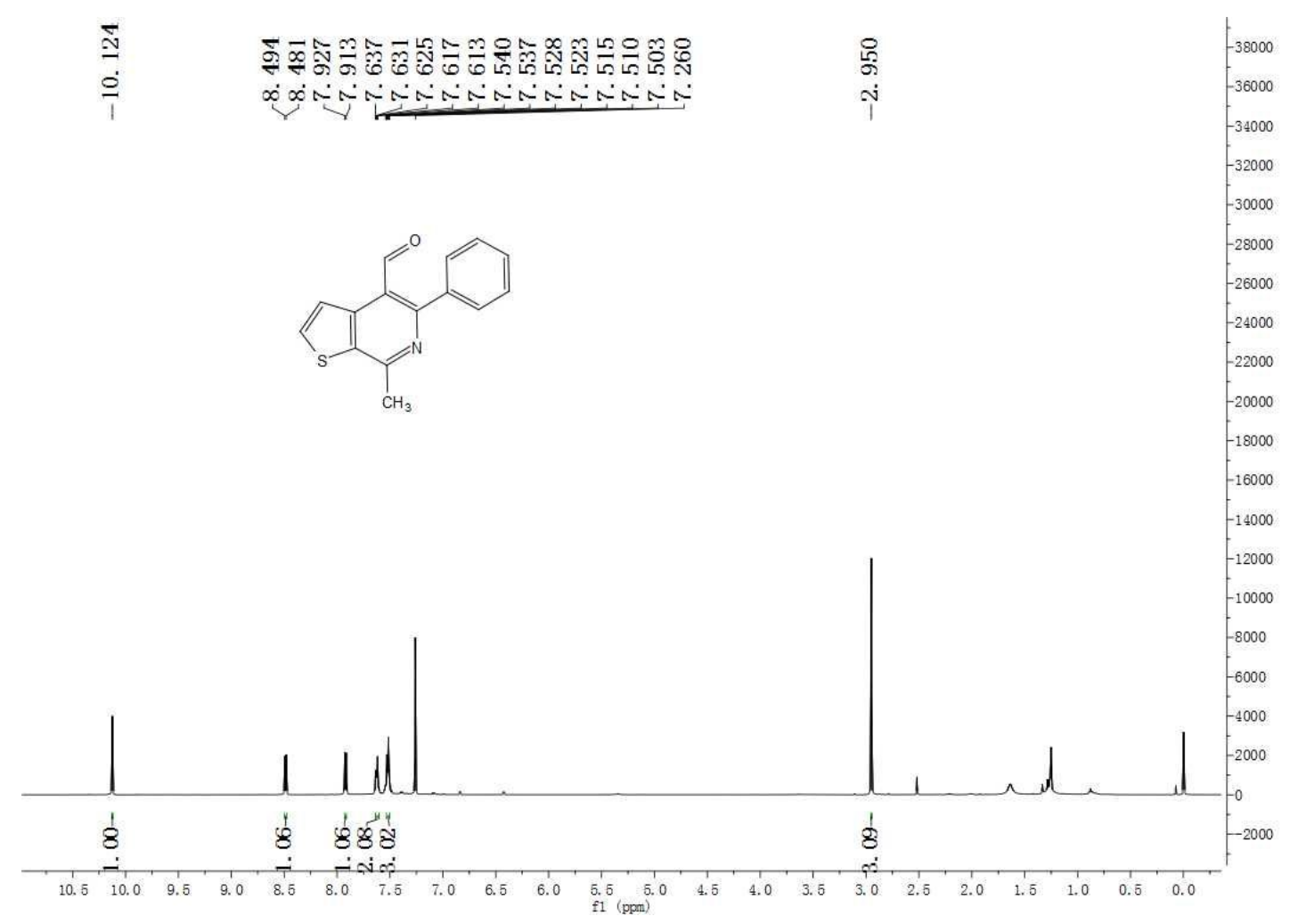

Figure S95. $400 \mathrm{MHz}{ }^{1} \mathrm{H}$ NMR spectrum of $\mathbf{4 w}$ in $\mathrm{CDCl}_{3}$

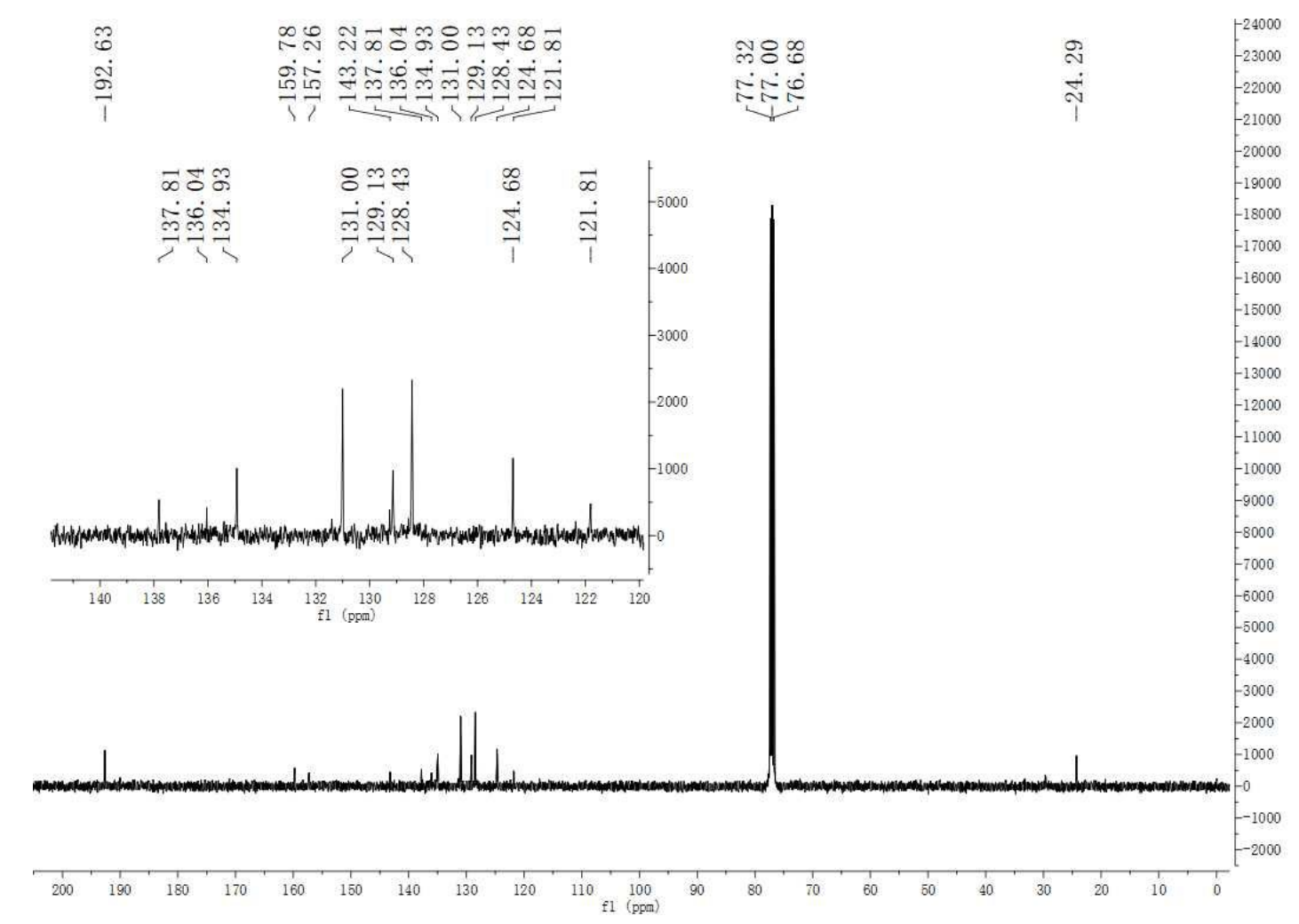

Figure S96. $100 \mathrm{MHz}{ }^{13} \mathrm{C}\left\{{ }^{1} \mathrm{H}\right\}$ NMR spectrum of $\mathbf{4 w}$ in $\mathrm{CDCl}_{3}$. 


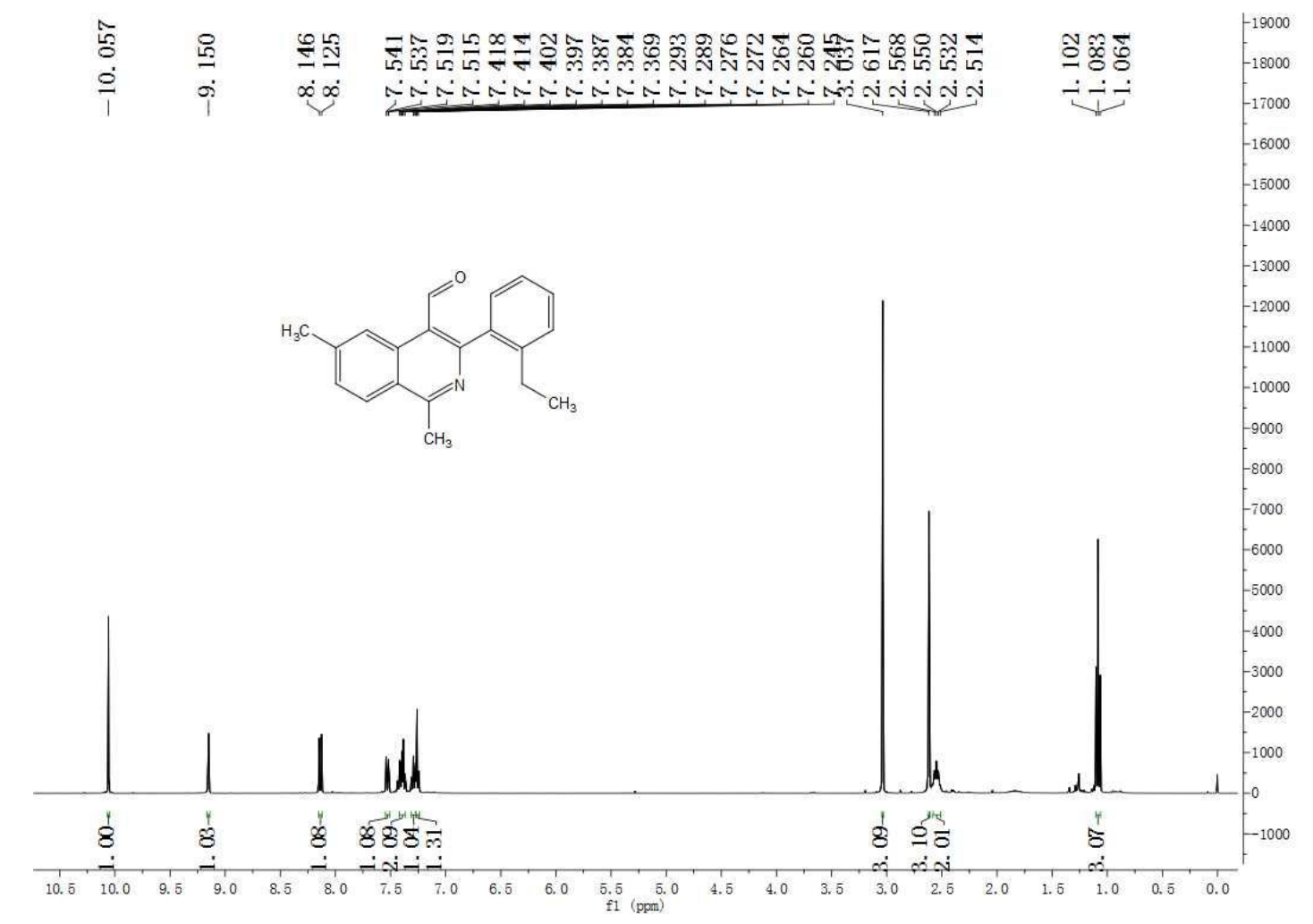

Figure S97. $400 \mathrm{MHz}{ }^{1} \mathrm{H}$ NMR spectrum of $\mathbf{4 x}$ in $\mathrm{CDCl}_{3}$

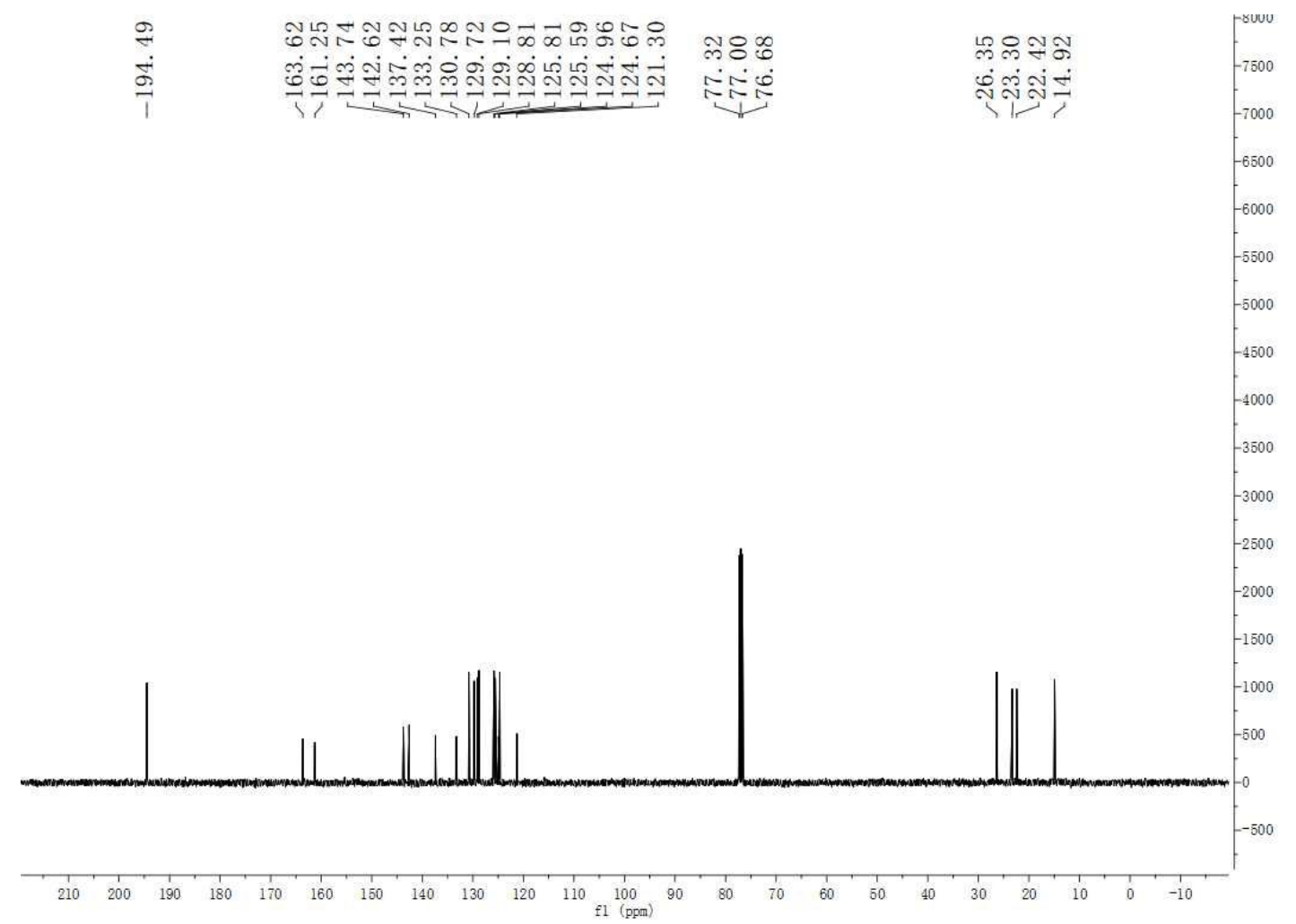

Figure S98. $100 \mathrm{MHz}{ }^{13} \mathrm{C}\left\{{ }^{1} \mathrm{H}\right\} \mathrm{NMR}$ spectrum of $\mathbf{4 x}$ in $\mathrm{CDCl}_{3}$. 


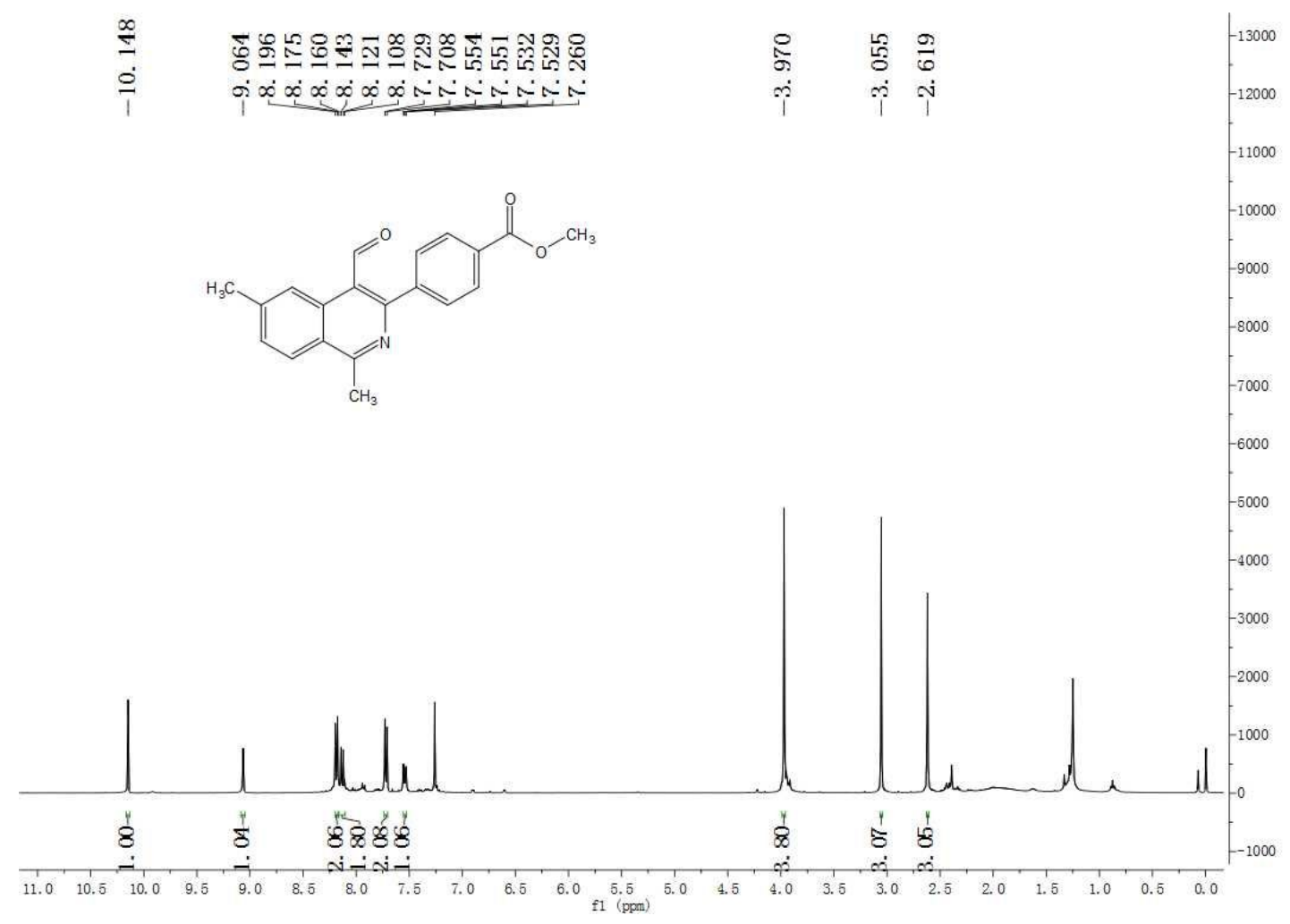

Figure S99. $400 \mathrm{MHz}{ }^{1} \mathrm{H}$ NMR spectrum of $4 \mathbf{y}$ in $\mathrm{CDCl}_{3}$

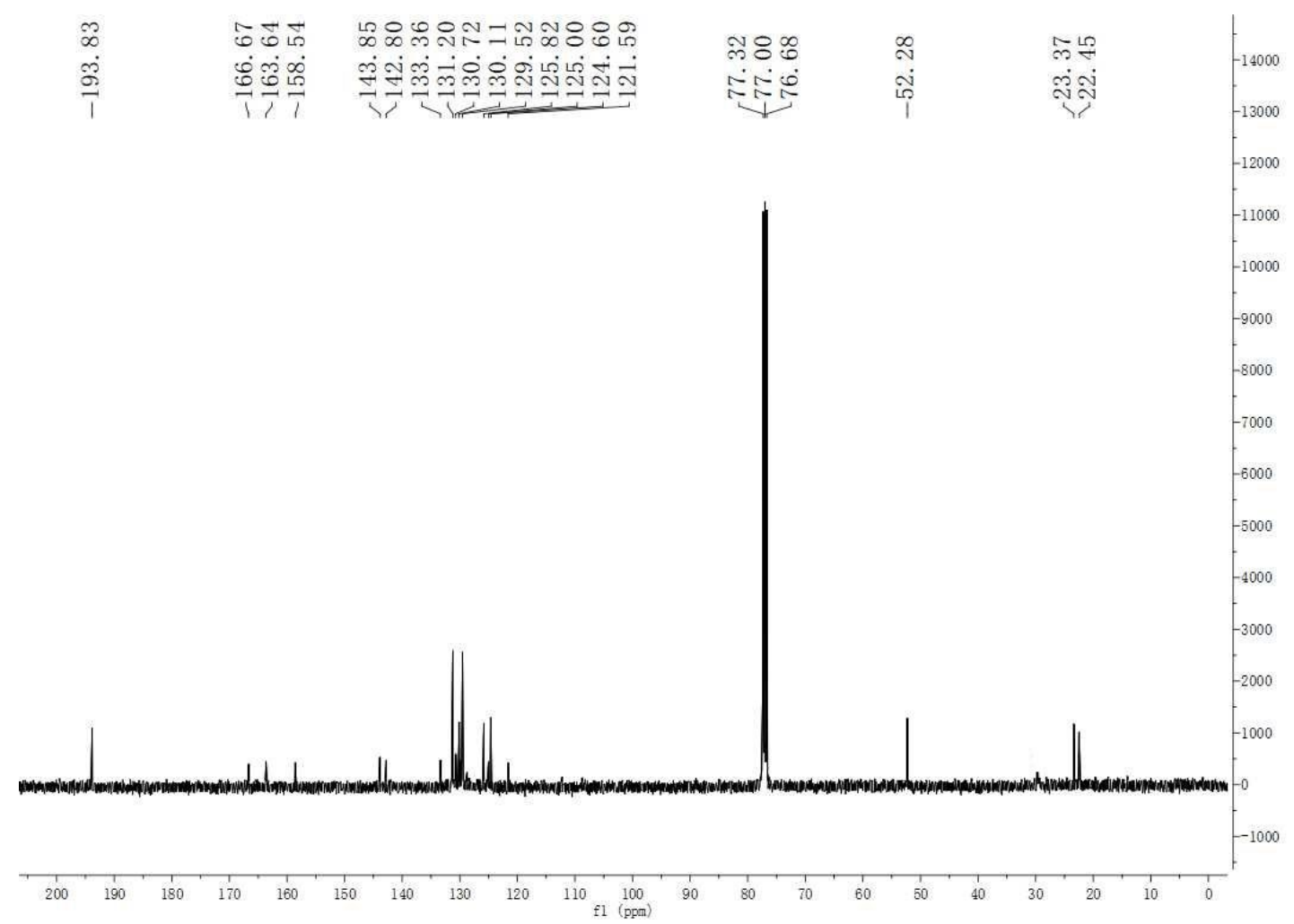

Figure S100. $100 \mathrm{MHz}{ }^{13} \mathrm{C}\left\{{ }^{1} \mathrm{H}\right\}$ NMR spectrum of $\mathbf{4 y}$ in $\mathrm{CDCl}_{3}$. 


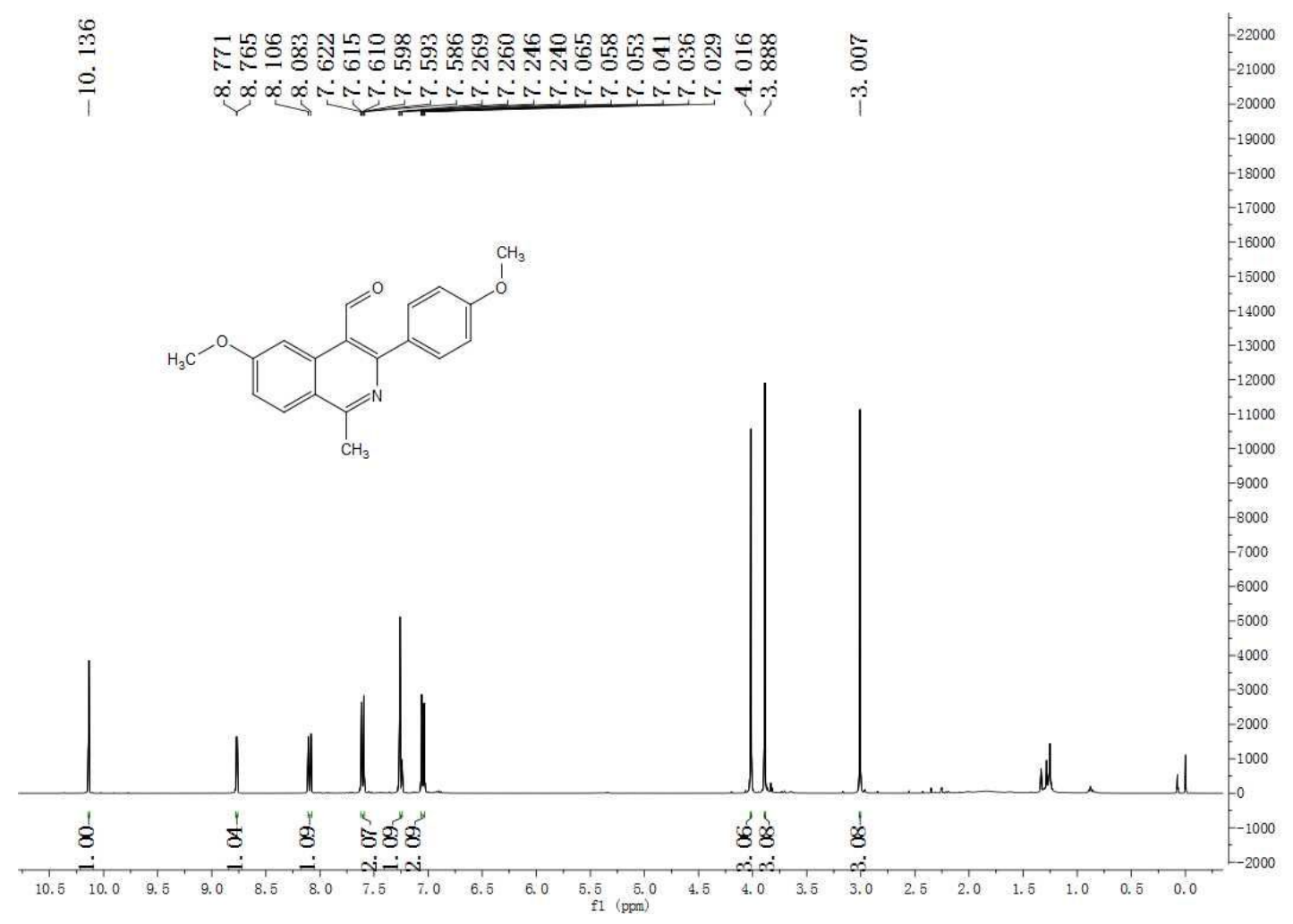

Figure S101. $400 \mathrm{MHz}{ }^{1} \mathrm{H} \mathrm{NMR}$ spectrum of $\mathbf{4 z}$ in $\mathrm{CDCl}_{3}$

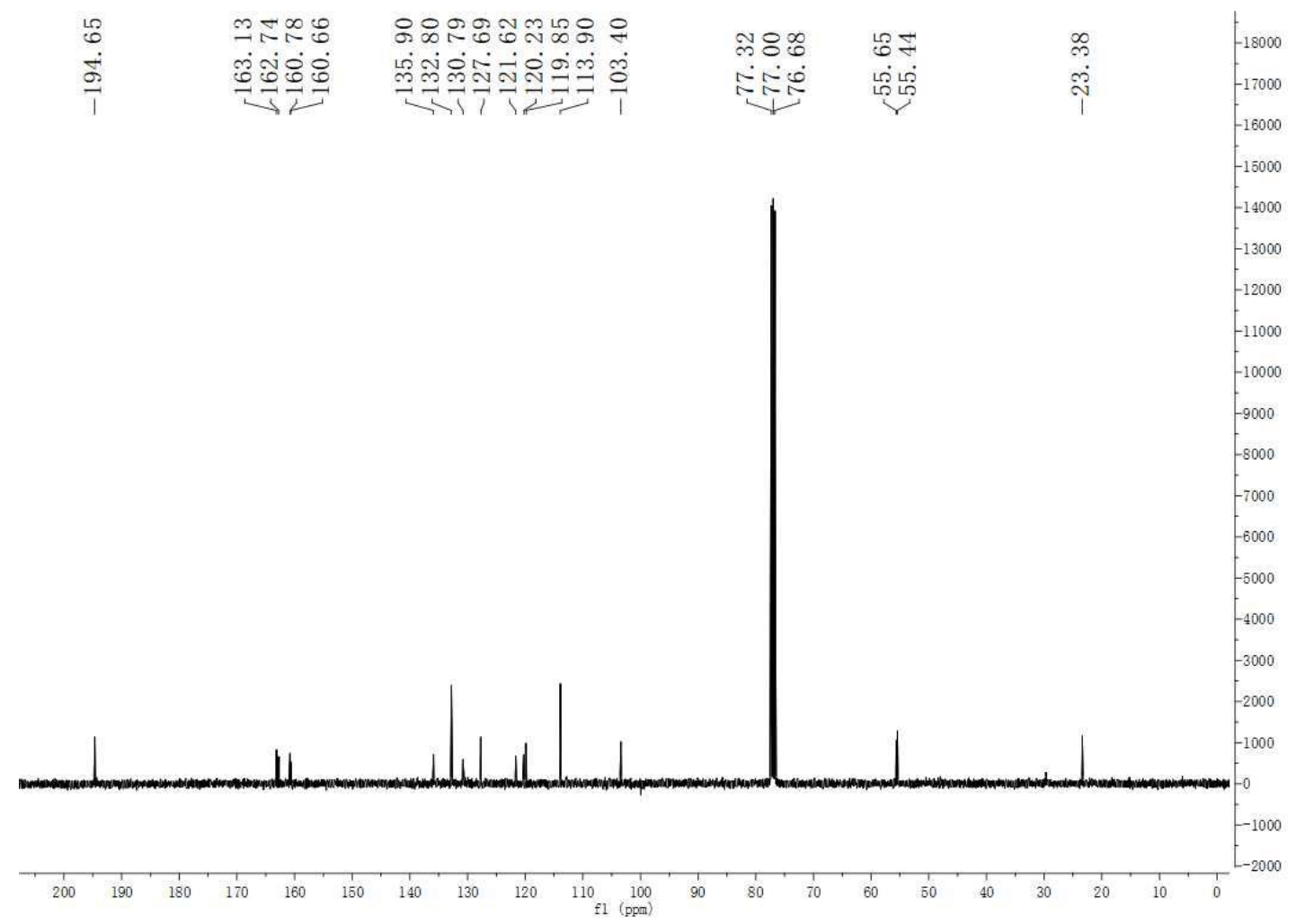

Figure S102. $100 \mathrm{MHz}{ }^{13} \mathrm{C}\left\{{ }^{1} \mathrm{H}\right\} \mathrm{NMR}$ spectrum of $\mathbf{4 z}$ in $\mathrm{CDCl}_{3}$. 


\section{X-ray crystallographic data}

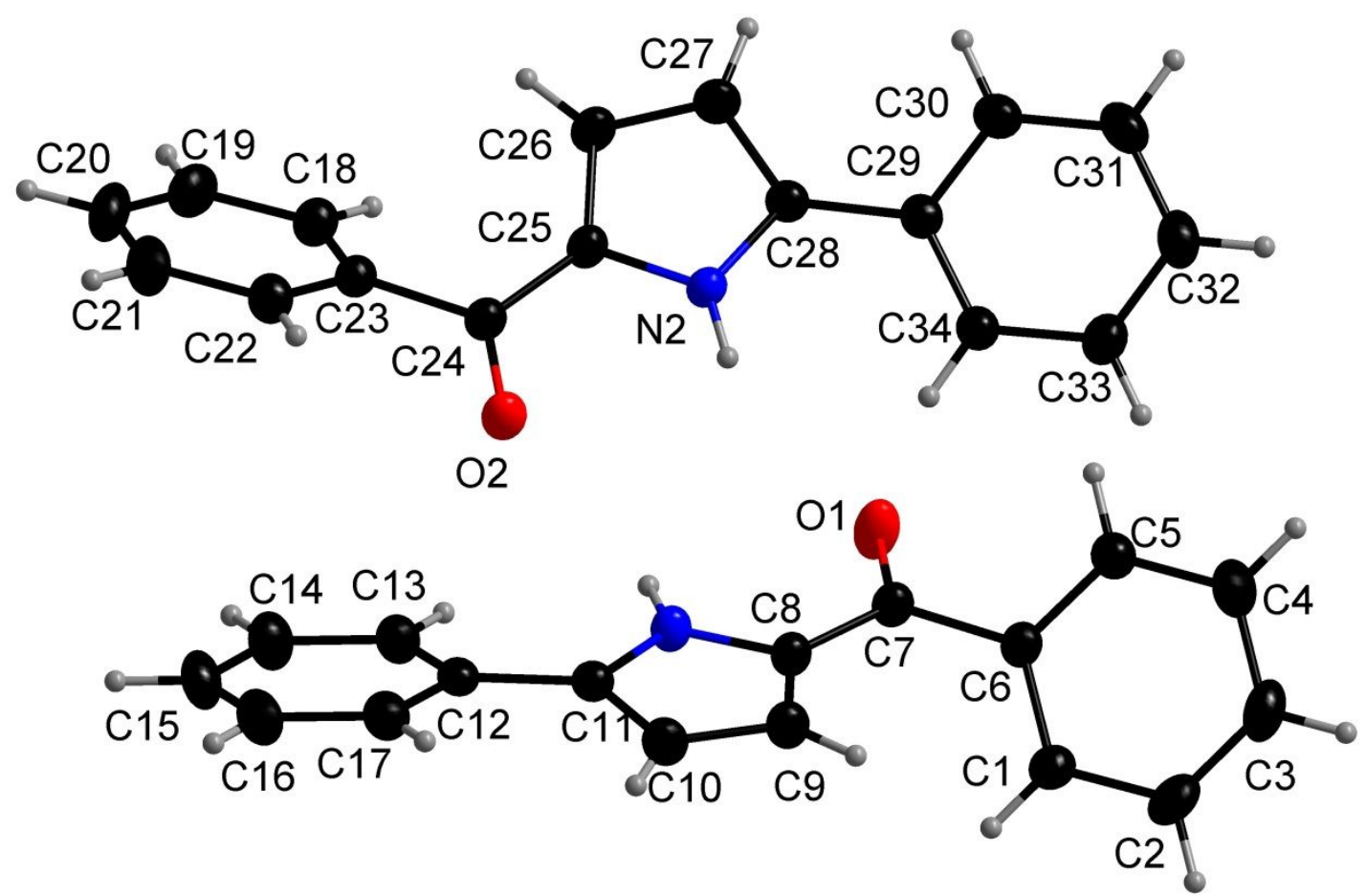

Figure S103. The ORTEP diagram of $\mathbf{3 a}$ (thermal ellipsoids are shown at 50\% probability) 
Sample Preparation: A crystalline solid was obtained via slow evaporation of compound 3a in EA: hexane $=1: 6$ at room temperature.

Crystal data and structure refinement for compound 3a (CCDC: 2023854)

Table S1 Crystal data and structure refinement for $3 \mathrm{a}$.

Identification code

$3 \mathrm{a}$

Empirical formula

$\mathrm{C}_{34} \mathrm{H}_{26} \mathrm{~N}_{2} \mathrm{O}_{2}$

Formula weight

494.57

Temperature/K

293(2)

Crystal system

triclinic

Space group

P-1

$\mathrm{a} / \AA \AA$

9.6559(3)

$\mathrm{b} / \AA$

$10.0445(3)$

$\mathrm{c} / \AA \AA$

$14.3756(5)$

$\alpha /^{\circ}$

$103.5340(10)$

$\beta /{ }^{\circ}$

93.3480(10)

$\gamma /{ }^{\circ}$

$107.2230(10)$

Volume $/ \AA^{3}$

1282.47(7)

Z

$\rho_{\text {calc }} \mathrm{g} / \mathrm{cm}^{3}$

2

$\mu / \mathrm{mm}^{-1}$

1.281

0.080

$\mathrm{F}(000)$

520.0

Crystal size $/ \mathrm{mm}^{3}$

$0.26 \times 0.22 \times 0.16$

Radiation

$\operatorname{MoK} \alpha(\lambda=0.71076)$

$2 \Theta$ range for data collection ${ }^{\circ}$

5.906 to 54.876

Index ranges

$-12 \leq \mathrm{h} \leq 12,-13 \leq \mathrm{k} \leq 13,-18 \leq 1 \leq 18$

Reflections collected 18950

Independent reflections

$5781\left[\mathrm{R}_{\text {int }}=0.0242, \mathrm{R}_{\text {sigma }}=0.0244\right]$

Data/restraints/parameters

$5781 / 0 / 343$

Goodness-of-fit on $\mathrm{F}^{2}$

1.030

Final $\mathrm{R}$ indexes $[\mathrm{I}>=2 \sigma(\mathrm{I})]$

$\mathrm{R}_{1}=0.0441, \mathrm{wR}_{2}=0.1026$

Final $\mathrm{R}$ indexes [all data]

$\mathrm{R}_{1}=0.0582, \mathrm{wR}_{2}=0.1138$

Largest diff. peak/hole / e $\AA^{-3}$

$0.21 /-0.17$ 


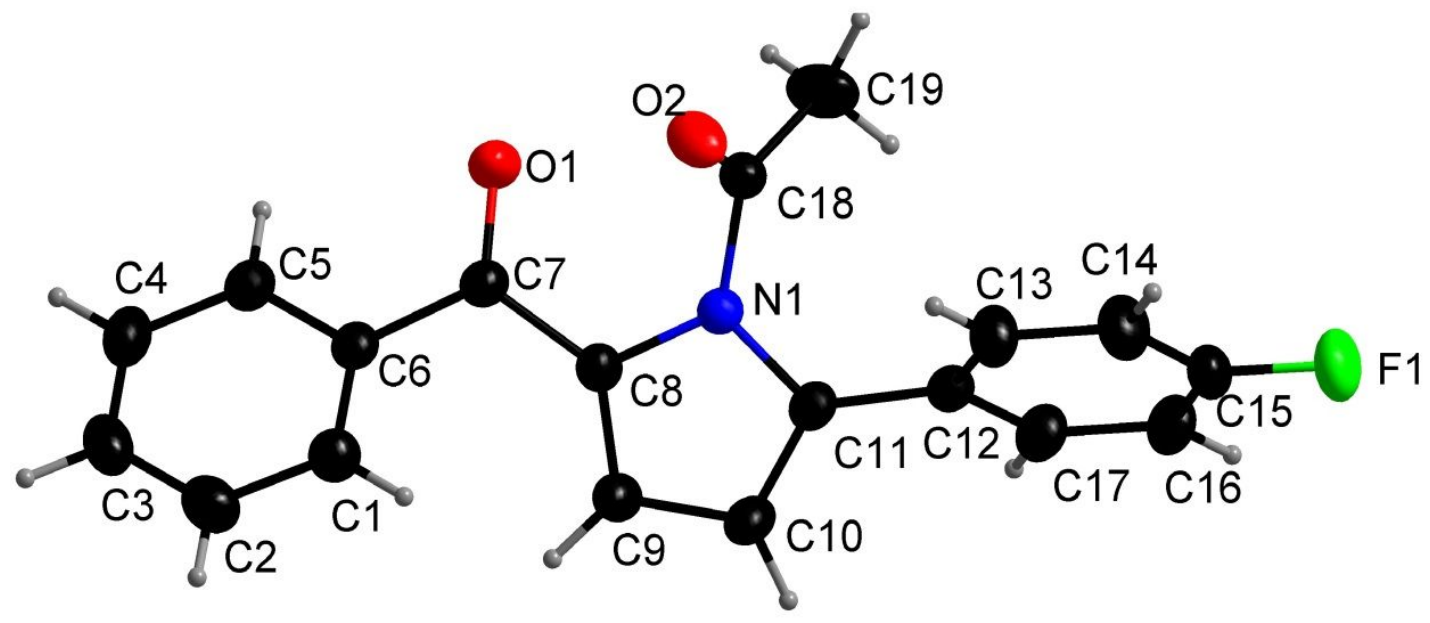

Figure S104. The ORTEP diagram of 3w (thermal ellipsoids are shown at 50\% probability) 
Sample Preparation: A crystalline solid was obtained via slow evaporation of compound 3w in EA: hexane $=1: 7$ at room temperature.

Crystal data and structure refinement for compound 3w (CCDC: 2023858)

Table S2 Crystal data and structure refinement for $3 \mathrm{w}$.

Identification code

Empirical formula

Formula weight

Temperature/K

Crystal system

Space group

$\mathrm{a} / \AA$

$\mathrm{b} / \AA$

$\mathrm{c} / \AA$

$\alpha /^{\circ}$

$\beta /{ }^{\circ}$

$\gamma /{ }^{\circ}$

Volume $/ \AA^{3}$

Z

$\rho_{\text {calc }} \mathrm{g} / \mathrm{cm}^{3}$

$\mu / \mathrm{mm}^{-1}$

$\mathrm{F}(000)$

Crystal size $/ \mathrm{mm}^{3}$

Radiation

$2 \Theta$ range for data collection ${ }^{\circ}$

Index ranges

Reflections collected

Independent reflections

Data/restraints/parameters

Goodness-of-fit on $\mathrm{F}^{2}$

Final $\mathrm{R}$ indexes $[\mathrm{I}>=2 \sigma(\mathrm{I})]$

Final $\mathrm{R}$ indexes [all data]

Largest diff. peak/hole / e $\AA^{-3}$
$3 \mathrm{w}$

$\mathrm{C}_{19} \mathrm{H}_{14} \mathrm{FNO}_{2}$

307.31

293(2)

triclinic

P-1

9.2551(4)

$9.7521(4)$

$9.9640(5)$

$79.6830(10)$

$62.7520(10)$

$75.3920(10)$

$771.56(6)$

2

1.323

0.094

320.0

$0.26 \times 0.22 \times 0.18$

$\operatorname{MoK} \alpha(\lambda=0.71076)$

5.976 to 54.942

$-12 \leq \mathrm{h} \leq 11,-12 \leq \mathrm{k} \leq 12,-12 \leq 1 \leq 12$

11154

$3456\left[\mathrm{R}_{\mathrm{int}}=0.0237, \mathrm{R}_{\mathrm{sigma}}=0.0252\right]$

$3456 / 0 / 209$

1.056

$\mathrm{R}_{1}=0.0454, \mathrm{wR}_{2}=0.1121$

$\mathrm{R}_{1}=0.0599, \mathrm{wR}_{2}=0.1215$

$0.17 /-0.18$ 


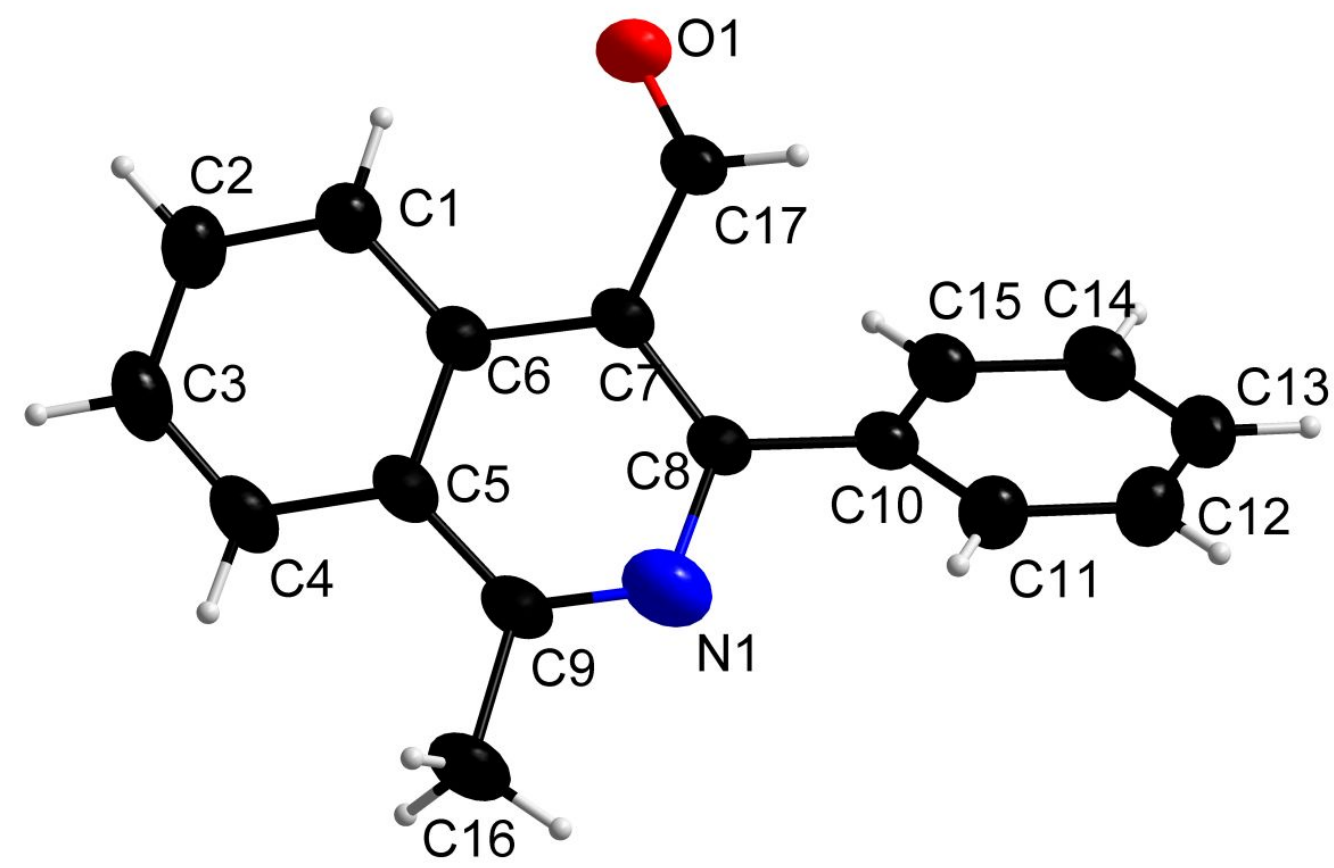

Figure S105. The ORTEP diagram of $\mathbf{4 a}$ (thermal ellipsoids are shown at 50\% probability)

Sample Preparation: A crystalline solid was obtained via slow evaporation of 
compound 4a in EA: hexane= 1: 4 at room temperature.

Crystal data and structure refinement for compound 4a (CCDC: 2023853)

Table S3 Crystal data and structure refinement for $4 a$.

Identification code

$4 a$

Empirical formula

$\mathrm{C}_{17} \mathrm{H}_{13} \mathrm{NO}$

Formula weight

247.28

Temperature/K

299.26(10)

Crystal system

triclinic

Space group

P-1

$\mathrm{a} / \AA$

8.4462(4)

$\mathrm{b} / \AA$

8.9559(4)

$\mathrm{c} / \AA$

9.0736(4)

$\alpha /{ }^{\circ}$

91.876(4)

$\beta /{ }^{\circ}$

92.266(4)

$\gamma /{ }^{\circ}$

$110.478(4)$

Volume $/ \AA^{3}$

$641.69(5)$

Z

2

$\rho_{\text {calc }} \mathrm{g} / \mathrm{cm}^{3}$

1.280

$\mu / \mathrm{mm}^{-1}$

0.080

$\mathrm{F}(000)$

260.0

Crystal size $/ \mathrm{mm}^{3}$

$0.41 \times 0.23 \times 0.12$

Radiation

$2 \Theta$ range for data collection ${ }^{\circ}$

$\operatorname{MoK} \alpha(\lambda=0.71073)$

Index ranges

Reflections collected

4.498 to 56.56

$-11 \leq \mathrm{h} \leq 11,-11 \leq \mathrm{k} \leq 11,-11 \leq 1 \leq 12$

10443

Independent reflections

$3149\left[\mathrm{R}_{\text {int }}=0.0274, \mathrm{R}_{\text {sigma }}=0.0298\right]$

Data/restraints/parameters

$3149 / 0 / 173$

Goodness-of-fit on $\mathrm{F}^{2}$

1.129

Final $R$ indexes $[\mathrm{I}>=2 \sigma(\mathrm{I})]$

$\mathrm{R}_{1}=0.0606, \mathrm{wR}_{2}=0.1617$

Final $\mathrm{R}$ indexes [all data]

$\mathrm{R}_{1}=0.0897, \mathrm{wR}_{2}=0.1803$

Largest diff. peak/hole / e $\AA^{-3}$

$0.14 /-0.17$ 